\title{
Cyclic Triaxial Tests of the Bootlegger Cove Formation, Anchorage, Alaska
}

\section{U.S. GEOLOGICAL SURVEY BULLETIN 1825}

A cooperative research project between the U.S. Geological Survey and the State of Alaska Division of

Geological and Geophysical Surveys

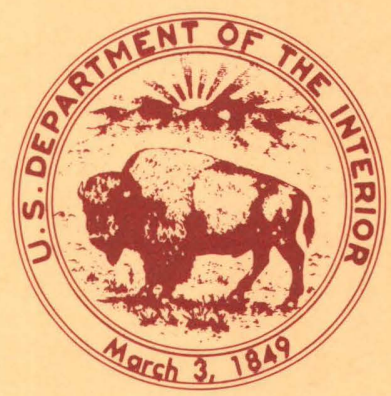





\title{
Cyclic Triaxial Tests of the Bootlegger Cove Formation, Anchorage, Alaska
}

\author{
By POUL V. LADE, RANDALL G. UPDIKE, \\ and DAVID A. COLE
}

A cooperative research project between the U.S. Geological Survey and the

State of Alaska Division of Geological and Geophysical Surveys 


\title{
DEPARTMENT OF THE INTERIOR DONALD PAUL HODEL, Secretary
}

\author{
U. S. GEOLOGICAL SURVEY
}

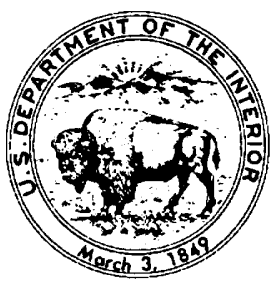

Dallas L. Peck, Director

Any use of trade names is for descriptive purposes only and does not imply endorsement by the U.S. Geological Survey.

For sale by the

Books and Open-File Reports Section

U.S. Geological Survey

Federal Center

Box 25425

Denver, CO 80225

Library of Congress Cataloging-in-Publication Data

Lade, $P$.

Cyclic triaxial tests of the Bootlegger Cove Formation, Anchorage, Alaska.

(U.S. Geological Survey bulletin ; 1825)

"A cooperative research project between the U.S. Geological Survey and the State of Alaska Division of Geological and Geophysical Surveys."

Bibliography: $p$.

Supt. of Docs. no.: I 19.3:1825

1. Soils-Alaska-Anchorage Region-Testing. 2. Shear strength of soils-

Testing. 3. Bootlegger Cove Formation (Alaska) I. Updike, Randall G.

II. Cole, David A. III. Alaska. Division of Geological and Geophysical

Surveys. IV. Title. V. Series.

QE75.B9 no. $1825 \quad 557.3$ s $\left[624.1^{\prime} 762\right] \quad 87-600446$

[TA710.3A4] 


\title{
CONTENTS
}

\author{
Glossary of symbols used VI \\ Abstract 1 \\ Introduction 1 \\ Scope 1 \\ Acknowledgments 2 \\ Regional geologic history 2 \\ Tectonic setting 2 \\ Quaternary history $\mathbf{3}$ \\ Engineering geologic facies of the Bootlegger Cove Formation 3
}

Geologic history of the site 4

Static engineering characterization of the site 7

Field sampling and logging 7

Dynamic laboratory testing program 7

Unconsolidated-undrained tests 8

Equipment 8

Testing procedure 8

Consolidated-undrained tests 9

Equipment 9

Testing procedure 9

Cyclic loading tests $\mathbf{1 0}$

Equipment 10

Testing procedure $\mathbf{1 0}$

Results of laboratory testing $\mathbf{1 1}$

Soil index tests 11

Static tests 11

Cyclic loading tests 16

Strength relations for intact specimens 16

Discussion of cyclic stress ratio $\mathbf{1 8}$

Strength relations for remolded specimens 18

Comparison of strength relations for intact and remolded specimens 19

Shear moduli 22

Damping ratios 23

Summary and conclusions from laboratory testing $\mathbf{2 4}$

References cited 26

\section{FIGURES}

1. Photograph of the Turnagain Heights landslide 2

2. Generalized map showing major faults in the vicinity of Anchorage 3

3. Generalized map showing the location of the sample site 4

4. Map showing the location of boreholes and cross-section lines 4

5. Geologic cross section along line $A-A^{\prime} 5$

6. Geologic cross section along line B-B' 6

7. Photograph of triaxial testing equipment used for UU tests 8

8. Photograph of triaxial testing equipment used for static ICU tests 9

9. Photograph of cyclic triaxial testing equipment 10

10. Plasticity chart for samples $\mathbf{1 1}$ 
11. Graph showing undrained shear strength versus water content derived from UU and ICU tests 14

12. The $p-q$ diagram showing effective normal stress versus maximum shearing stress determined by ICU tests 16

13. Photograph of specimen CT-5 (F.IV) after consolidation and after failure by cyclic loading 17

14. Photograph of specimen CT-3 (F.III) after consolidation and after failure by cyclic loading $\mathbf{1 8}$

15. Photograph of specimen CT-4 (F.IV) after consolidation and after failure by cyclic loading 19

16-47. Graphs showing:

16. Peak-to-peak axial strain versus number of cycles for intact samples at $K_{c}=1.022$

17. Cyclic stress ratio from UU tests versus number of cycles for intact specimens at $K_{c}=1.0 \quad 23$

18. Cyclic stress ratio from ICU tests versus number of cycles for intact specimns at $K_{c}=1.0 \quad 24$

19. Maximum axial strain versus number of cycles for intact specimens at $K_{c}=1.5 \quad 25$

20. Maximum axial strain versus number of cycles for intact specimens at $K_{c}=2.0 \quad 26$

21. Cyclic stress ratio from UU tests versus number of cycles for intact specimens at $K_{c}=1.5 \quad 27$

22. Cyclic stress ratio from ICU tests versus number of cycles for intact specimens at $K_{c}=1.528$

23. Cyclic stress ratio from UU tests versus number of cycles for intact specimens at $K_{c}=2.0 \quad 29$

24. Cyclic stress ratio from ICU tests versus number of cycles for intact specimens at $K_{c}=2.0 \quad 30$

25. Cyclic stress ratio from UU tests versus number of cycles for intact specimens at $K_{c}=1.0,1.5$, and 2.031

26. Peak-to-peak axial strain versus number of cycles for remolded specimens at $K_{c}=1.0 \quad 32$

27. Maximum axial strain versus number of cycles for remolded specimens at $K_{c}=1.5 \quad 33$

28. Maximum axial strain versus number of cycles for remolded specimens at $K_{c}=2.0 \quad 34$

29. Cyclic stress ratio from UU tests versus number of cycles for remolded specimens at $K_{c}=1.0 \quad 35$

30. Cyclic stress ratio from UU tests versus number of cycles for remolded specimens at $K_{c}=1.5 \quad 36$

31. Cyclic stress ratio from UU tests versus number of cycles for remolded specimens at $K_{c}=2.0 \quad 37$

32. Cyclic stress ratio from ICU tests versus number of cycles for remolded specimens at $K_{c}=1.0 \quad 38$

33. Cyclic stress ratio from ICU tests versus number of cycles for remolded specimens at $K_{c}=1.5 \quad 39$

34. Cyclic stress ratio from ICU tests versus number of cycles for remolded specimens at $K_{c}=2.0 \quad 40$

35. Cyclic stress ratio from UU tests versus number of cycles for remolded specimens at $K_{c}=1.0,1.5$, and 2.041

36. Cyclic stress ratio from ICU tests versus number of cycles for remolded specimens at $K_{c}=1.0,1.5$, and $2.0 \quad 42$ 
37. A comparison of cyclic stress ratios for intact (UU tests) specimens and remolded (ICU tests) specimens $\mathbf{4 3}$

38. A comparison of cyclic stress ratios for intact (estimated ICU tests) and remolded (measured ICU tests) specimens $\mathbf{4 4}$

39. Normalized shear moduli for intact specimens using shear strengths from UU tests $\mathbf{4 5}$

40. Normalized shear moduli for intact specimens using shear strengths from estimated ICU tests $\mathbf{4 5}$

41. Normalized shear moduli for remolded specimens using shear strengths from UU tests 46

42. Normalized shear moduli for remolded specimens using shear strengths from ICU tests 46

43. A comparison of shear moduli versus number of cycles for intact and remolded specimens at $K_{c}=1.0 \quad 47$

44. A comparison of shear moduli versus number of cycles for intact and remolded specimens at $K_{c}=1.5 \quad 48$

45. A comparison of shear moduli versus number of cycles for intact and remolded specimens at $K_{c}=2.0 \quad 49$

46. Damping ratios versus percent strain for intact specimens $\mathbf{5 0}$

47. Damping ratios versus percent strain for remolded specimens

\section{TABLES}

1. Summary of Atterberg limit and hydrometer tests $\mathbf{1 2}$

2. Summary of torvane and UU triaxial tests 13

3. Summary of ICU triaxial tests $\mathbf{1 5}$

4. Summary of initial and stress conditions for cyclic tests on intact specimens 20

5. Summary of initial and stress conditions for cyclic tests on remolded specimens 21

\section{CONVERSION FACTORS}

For readers who wish to convert measurements from the metric system of units to the inch-pound system of units, the conversion factors are listed below.

\begin{tabular}{|c|c|c|}
\hline Metric unit & Multiply by & To obtain inch-pound unit \\
\hline millimeter $(\mathrm{mm})$ & 0.03937 & inch \\
\hline centimeter $(\mathrm{cm})$ & 0.3937 & inch \\
\hline meter $(\mathrm{m})$ & 3.281 & foot $(\mathrm{ft})$ \\
\hline centimeter ${ }^{2}\left(\mathrm{~cm}^{2}\right)$ & 0.1550 & inch $^{2}$ \\
\hline centimeter $\left(\mathrm{cm}^{3}\right)$ & 0.06102 & inch $^{3}$ \\
\hline kilogram (kg) & 2.205 & pound $(\mathrm{lb})$ \\
\hline metric ton & 1.102 & ton, short $(2000 \mathrm{lb})$ \\
\hline $\begin{array}{l}\text { kilogram } / \text { centimeter }^{2} \\
\left(\mathrm{~kg} / \mathrm{cm}^{2}\right)\end{array}$ & 14.223 & pound/inch ${ }^{2}(\mathrm{psi})$ \\
\hline $\begin{array}{l}\text { gram/centimeter }{ }^{3} \\
\left(\mathrm{~g} / \mathrm{cm}^{3}\right)\end{array}$ & 62.43 & pound $/$ foot $^{3}\left(\mathrm{lb} / \mathrm{ft}^{3}\right)$ \\
\hline
\end{tabular}




\begin{tabular}{|c|c|c|c|}
\hline$A$ & Activity of clay; PI/percent clay & $S_{u}$ & Undrained shear strength \\
\hline$A_{o}$ & Initial cross-sectional area of specimen & $t_{50}^{u}$ & Time to reach 50 percent consolidation \\
\hline$A_{c}$ & $\begin{array}{l}\text { Cross-sectional area of specimen after consoli- } \\
\text { dation }\end{array}$ & $\begin{array}{l}t_{100} \\
U\end{array}$ & $\begin{array}{l}\text { Time to reach } 100 \text { percent consolidation } \\
\text { Pore pressure }\end{array}$ \\
\hline$B$ & $\begin{array}{l}\text { (Measured pore pressure increase)/(applied } \\
\text { confining pressure increase) }\end{array}$ & $U_{f}$ & $\begin{array}{l}\text { Pore pressure at failure } \\
\text { Maximum pore pressure }\end{array}$ \\
\hline CL & $\begin{array}{l}\text { Unified Classification symbol for clay with } \\
\text { low plasticity }\end{array}$ & $V_{0}$ & $\begin{array}{l}\text { Unconsolidated-undrained (test) } \\
\text { Initial volume of specimen }\end{array}$ \\
\hline CU & Consolidated-undrained (test) & $w / c$ & Water content \\
\hline CUPI & $\begin{array}{l}\text { Consolidated-undrained cyclic (pulsating) test } \\
\text { on intact specimen }\end{array}$ & $\begin{array}{l}\gamma \\
\gamma_{\text {wet }}\end{array}$ & $\begin{array}{l}\text { Single-amplitude shear strain } \\
\text { Wet density }\end{array}$ \\
\hline CUPR & $\begin{array}{l}\text { Consolidated-undrained cyclic (pulsating) test } \\
\text { on remolded specimen }\end{array}$ & $\Delta \boldsymbol{V}_{\text {consol }}$ & $\begin{array}{l}\text { Volume change of specimen due to consoli- } \\
\text { dation }\end{array}$ \\
\hline $\begin{array}{c}c_{v} \\
D\end{array}$ & $\begin{array}{l}\text { Coefficient of consolidation } \\
\text { Damping ratio }\end{array}$ & $\Delta \delta_{\text {consol }}$ & $\begin{array}{l}\text { Vertical deformation of specimen due to con- } \\
\text { solidation }\end{array}$ \\
\hline $\begin{array}{l}D_{50} \\
G\end{array}$ & $\begin{array}{l}\text { Median particle diameter } \\
\text { Shear modulus }\end{array}$ & $\epsilon_{\text {1consol }}$ & $\begin{array}{l}\text { Vertical strain of specimen due to consoli- } \\
\text { dation }\end{array}$ \\
\hline$G_{s}$ & Specific gravity of soil particles & $\epsilon_{1 f}$ & Vertical strain at failure \\
\hline$H_{o}$ & Initial height of specimen & $\epsilon_{1 \max }$ & Maximum vertical strain \\
\hline $\begin{array}{l}H_{c} \\
\text { ICU }\end{array}$ & $\begin{array}{l}\text { Height of specimen after consolidation } \\
\text { Isotropically consolidated-undrained (test) }\end{array}$ & $\epsilon_{\text {veonsol }}$ & $\begin{array}{l}\text { Volumetric strain of specimen due to consoli- } \\
\text { dation }\end{array}$ \\
\hline$K_{c}$ & Consolidation stress ratio; $\sigma_{1 c} / \sigma_{3 c}$ & $\sigma_{1}$ & Principal applied stress in trixial cell \\
\hline LL & Liquid limit & $\sigma_{1 c}$ & Principal applied stress during consolidation \\
\hline$N$ & Number of load cycles applied to specimen & $\sigma_{3}$ & Confining pressure in triaxial cell \\
\hline$N_{f}$ & $\begin{array}{l}\text { Number of load cycles to cause failure of } \\
\text { specimen }\end{array}$ & $\begin{array}{l}\sigma_{3 c} \\
\sigma_{3 f}^{\prime}\end{array}$ & $\begin{array}{l}\text { Confining pressure during consolidation } \\
\text { Effective confining pressure at failure }\end{array}$ \\
\hline$N_{\max }$ & $\begin{array}{l}\text { Maximum number of load cycles applied to } \\
\text { specimen }\end{array}$ & $\begin{array}{l}\left(\sigma_{1}^{j}-\sigma_{3}\right)_{\max } \\
\left(\sigma_{1}^{\prime} / \sigma_{3}^{\prime}\right)_{\max }\end{array}$ & $\begin{array}{l}\text { Deviator stress } \\
\text { Effective stress ratio }\end{array}$ \\
\hline$P_{d p}$ & Cyclic (pulsating) deviator load & $\sigma_{d c}$ & Deviator stress during consolidation \\
\hline PI & Plasticity index; LL - PL & $\sigma_{d \max }$ & Maximum deviator stress applied to specimen; \\
\hline PL & Plastic limit & & $\sigma_{d c}+\sigma_{d p}$ \\
\hline$S_{p}$ & $\begin{array}{l}\text { Half of cyclic (pulsating) deviator stress; } \\
\sigma_{d p} / 2\end{array}$ & $\sigma_{d p}$ & $\begin{array}{l}\text { Cyclic (pulsating) deviator stress } \\
\text { Friction angle }\end{array}$ \\
\hline$S_{t}$ & Sensitivity; $S_{u}$ (intact) $/ S_{u}$ (remolded) & $\phi^{\prime}$ & Effective friction angle \\
\hline
\end{tabular}




\title{
Cyclic Triaxial Tests of the Bootlegger Cove Formation, Anchorage, Alaska
}

\author{
By Poul V. Lade', Randall G. Updike, and David A. Cole 2
}

\begin{abstract}
Earthquake-induced landslides in the Anchorage area have resulted primarily from cohesive soil failures within the Bootlegger Cove Formation. A suite of ten undisturbed samples from various formational facies were tested in an investigation of representative stress-strain and strength properties under static and cyclic loading conditions. A sequence of soil index property tests was followed by unconsolidated-undrained static triaxial tests on intact and remolded specimens, isotropically consolidated-undrained static triaxial tests on remolded specimens, and cyclic triaxial tests on intact and remolded specimens at various consolidation ratios. The intent of this testing program was to "calibrate" the static and dynamic behavior of the cohesive facies of the formation in the previously determined zone of failure. The results indicate that, at higher consolidation stress ratios, higher cyclic stress ratios are required to cause a given amount of strain for a finite number of cycles. Though the evidence is not conclusive, there is an indication that soils remolded in landslide areas have strengths equal to those of soils in areas that have not failed. Sensitivity values determined on these samples are substantially lower than those reported in the literature, which suggests that criteria other than sensitivity must be considered in evaluating the stability of the Bootlegger Cove Formation during earthquakes.
\end{abstract}

\section{INTRODUCTION}

The City of Anchorage lies within one of the most active tectonic regions of the world and is therefore subjected to frequent seismic events which have magnitudes as great as that of the catastrophic Prince William Sound earthquake of March 27, 1964. Moderate- to largemagnitude earthquakes can be expected to occur in the region within the design life of most major buildings now existing or planned for construction in the city. During

\footnotetext{
${ }^{1}$ School of Engineering and Applied Science, University of California, Los Angeles, California.

${ }^{2}$ DOWL Engineers, Inc., Anchorage, Alaska.
}

the 1964 earthquake the primary cause of property damage and loss of life in Anchorage was related to ground failure (landslides) that resulted from the intense shaking (fig. 1). These landslides have been attributed to three failure mechanisms: (1) gravity fall along unstable slopes, (2) liquefaction of silts and sands, and (3) collapse of sensitive silts and clays. The second and third types are primarily limited to the Bootlegger Cove Formation, which underlies much of Anchorage. Technical studies in the years immediately following the 1964 earthquake gave support to both of these mechanisms (for example, Shannon and Wilson, Inc., 1964; Kerr and Drew, 1965; Hansen, 1965; Seed and Wilson, 1967). However, recent research has firmly demonstrated that liquefaction of sands within the formation was not the primary cause of ground failure (Idriss and Moriwaki, 1982; Updike, 1983, 1984). Thus, interest has recently begun to focus on the cyclic stress-strain behavior of the cohesive soils of the formation although actual test data for these soils have been limited. A study of the cyclic strengths of the clay and silt was performed by Seed and Chan (1964) for the postearthquake investigations that were conducted by Shannon and Wilson, Inc., for the U.S. Army Corps of Engineers. This study utilized the then-emerging technology of cyclic testing of soils. In order to better assess the potential for further landslides during future earthquakes, it is necessary to more fully understand the cyclic stress behavior in the light of current perceptions of the formation.

\section{Scope}

The objective of this study was to establish with greater confidence the static and dynamic characteristics of the Bootlegger Cove Formation and, if possible, to relate these characteristics to basic soil index values. To achieve this objective, a comprehensive testing program was conducted to gain knowledge on formational dynamic behavior characteristics which could be applied to 


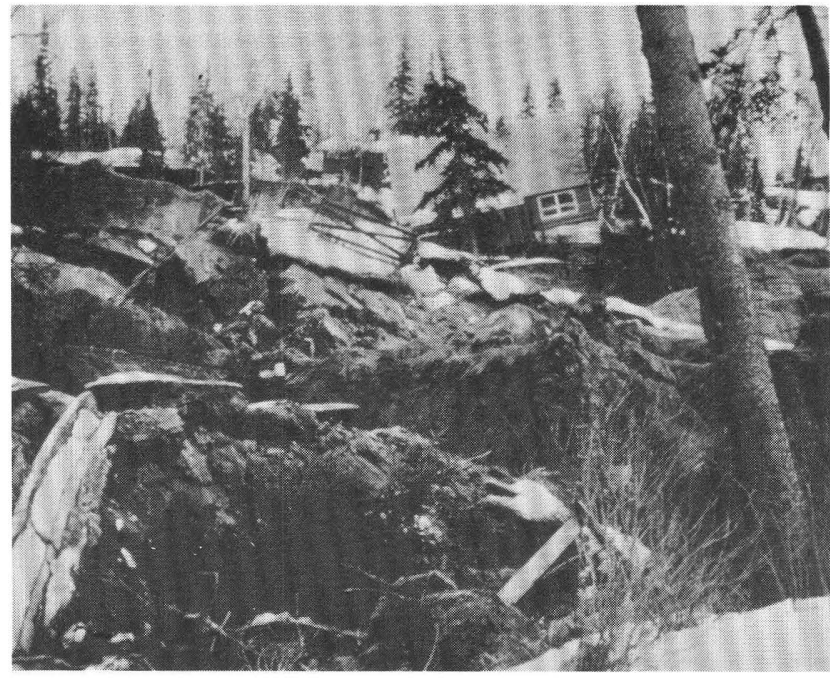

Figure 1. The Turnagain Heights landslide was one of several Anchorage landslides resultant from failure of the Bootlegger Cove Formation during the 1964 Prince William Sound earthquake (Photo from NOAA/EDS files, No. 140-2).

the formation on a regional scale. During the geotechnical foundation studies for a high-rise building in downtown Anchorage, high-quality, undisturbed, thin-walled Shelby-tube samples were acquired and were provided to the authors by the building owners, with the agreement that site location would remain confidential. The testing of those samples is the focus of this report, with primary emphasis on soils typical of the Bootlegger Cove Formation in downtown Anchorage. Samples that were found to be metastable and that, in some cases, began to deform immediately after extrusion from samplers were not included in this study because of the potential problems of disturbance during transportation, extrusion, and laboratory preparation. The intent of this study is to establish a benchmark of cyclic test data on "typical" cohesive soil samples of the Bootlegger Cove Formation, from which point future studies can focus on the metastable soil horizons that are critical to future seismic stability evaluations.

\section{Acknowledgments}

This project was supported by a grant from the Federal Emergency Management Agency (FEMA) to the Alaska Division of Emergency Services (ADES), which contracted the authors to conduct the research. The project was further supported by a cooperative agreement between the U.S. Geological Survey (USGS) and the Alaska Division of Geological and Geophysical Surveys (ADGGS) under the Earthquake Hazards Reduction Program. The testing was conducted at the geotechnical laboratories of DOWL Engineers, Anchorage; University of California-Los Angeles Civil Engineering Department; and ADGGS Engineering Geology Section. Catherine Ulery, Peter Glaesman, and Michael Pritchard (ADGGS) assisted with the cartography. Rodney Combellick (ADGGS), Harold Olsen (USGS), Henry Schmoll (USGS), and Hans Pulpan (University of AlaskaFairbanks Geophysical Institute) provided technical reviews of the manuscript. The owner and developer of the site where the samples were obtained has reserved the right to remain unnamed, but the drilling and field logistics support provided by that party made the project possible within the budget provided by FEMA-ADES and by USGS-ADGGS. The authors particularly wish to thank Alvaro Espinosa, (USGS, Golden, Colo.) who, through his USGS-funded Anchorage Earthquake Hazards Project, provided both the encouragement and organizational support necessary for the publication of this report.

\section{REGIONAL GEOLOGIC HISTORY}

The Anchorage area is located in the upper Cook Inlet region of south-central Alaska. This inlet has had a varied history during Quaternary time in response to fluctuations in sea level, advance and retreat of adjacent mountain glaciers, and tectonic uplift and subsidence. The geologic record produced by the interplay of these systems is indeed complex and not well understood; however, some generalizations can be made.

\section{Tectonic Setting}

Cook Inlet is situated in a tectonic forearc basin that is bounded to the west by the Bruin Bay-Castle Mountain fault system and to the east by the Border Ranges fault system (which includes the Knik fault along the west front of the Chugach Mountains) (fig. 2). Most of the regional seismicity can be attributed to underthrusting along the Benioff Zone of the plate boundary megathrust which extends beneath the inlet (Fogelman and others, 1978). There is, however, some evidence suggesting that both the Castle Mountain (Bruhn, 1979; Lahr and others, 1986) and Border Ranges fault systems (Updike and Ulery, 1983) may be active and capable of propagating moderate earthquakes. Each year earthquakes with magnitudes above 4.5 are felt in Anchorage as a result of this seismic setting.

The tectonic basin is bounded to the east in the Chugach Mountains by Mesozoic metamorphic rocks (graywackes, phyllites, metavolcanics, and argillites of the Valdez and McHugh Groups). To the west, the basin is confined by the igneous and metasedimentary rocks of the Alaska Range. Within the basin, and lying a few 


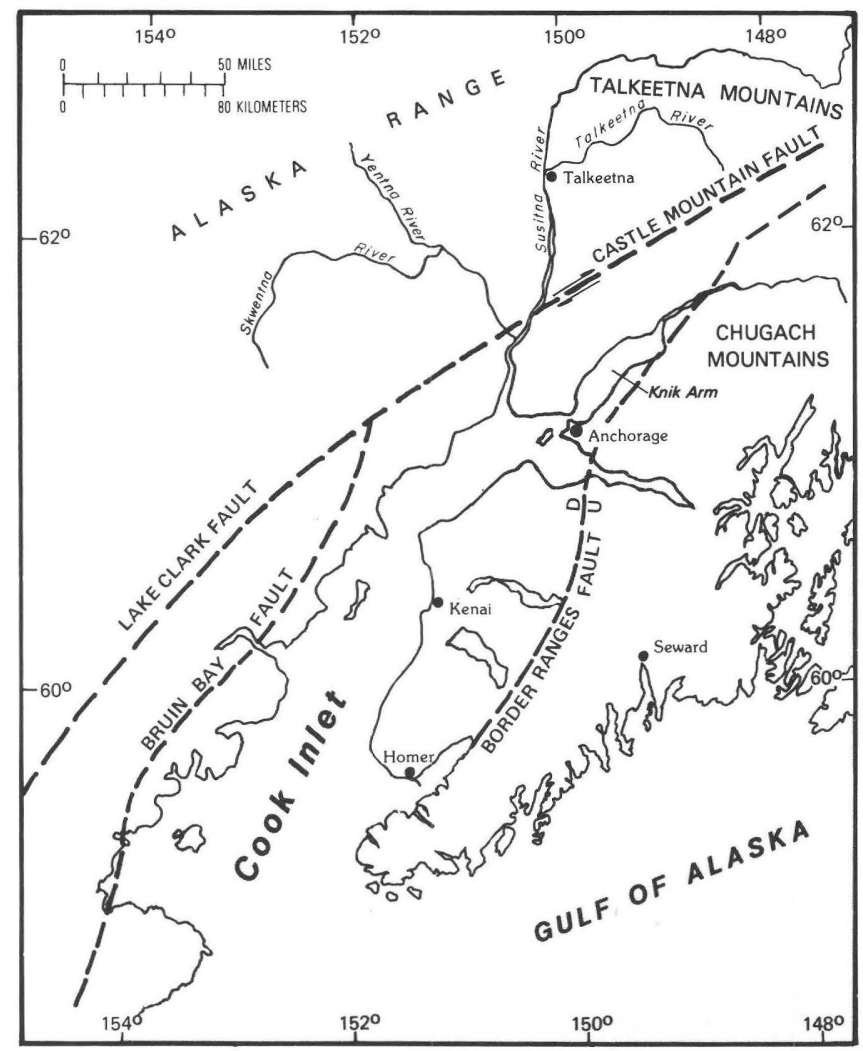

Figure 2. Generalized map showing major faults in the vicinity of Anchorage.

hundred meters below Anchorage, are Tertiary clastic sedimentary rocks that have been deposited in the structural depression; these sedimentary rocks wedge out against the older rocks along the basin boundaries.

\section{Quaternary History}

The Quaternary history of upper Cook Inlet has been discussed in considerable detail by Miller and Dobrovolny (1959), Karlstom (1964), Schmoll and Dobrovolny (1972), and Reger and Updike (1983). Karlstrom proposed that at least five major glaciations occurred in upper Cook Inlet which were, from oldest to youngest, Mount Susitna, Caribou Hills, Eklutna, Knik, and Naptowne glaciations. The three earlier glaciations (Mount Susitna, Caribou Hills, and Eklutna) were presumably far more extensive than the later ones (Knik and Naptowne), and ice of these earlier glaciations coalesced to fill the Cook Inlet trough. The later glaciations, though not as extensive, were capable of significantly restricting the movement of fresh and marine waters in the inlet. It is quite probable that glacially dammed lakes were produced during the late Pleistocene so that glaciofluvial, deltaic, lacustrine, and marine sedimentation were juxtaposed with ice-contact deposits.
The Bootlegger Cove Formation ${ }^{3}$ was a product of this type of glaciomarine/glaciolacustrine environment. Although the following discussion relates to this stratigraphic unit as exposed in the Anchorage area, the depositional environment was undoubtedly duplicated elsewhere in Cook Inlet at various times during the Quaternary, which resulted in several other Bootlegger Cove-type deposits.

The Bootlegger Cove Formation is a stratified sequence of clastic sediments that range from clay to boulders which, on the basis of paleontologic evidence (Schmidt, 1963), were deposited in brackish or marine waters. The formation is known to occur at shallow depths beneath most of the western half of metropolitan Anchorage, as well as northward in the Knik Arm area and westward to the Susitna River. Several radiometric dates have consistently yielded a late Wisconsin age (about 14,000 years B.P.) for a horizon in the upper part of the formation (Schmoll and others, 1972). Generally, the formation is underlain by glaciofluvial sands and gravel or by glacial till. Dependant upon the location, the formation may be overlain by till (for example, the Elmendorf Moraine), glaciofluvial sediments, or eolian silts and peat.

\section{Engineering Geologic Facies of the Bootlegger Cove Formation}

Seven sedimentary facies of the Bootlegger Cove Formation have been identified by Updike and Carpenter (1986) in order to better characterize intraformational variations of composition and geotechnical characteristics. Each facies is distinguishable as a function of subtle differences in depositional environment (for example, turbidity, energy regime) and postdepositional modifications (for example, overburden pressures, ground-water leaching). The defined facies are intricately intercalated so that the scale of units portrayed can vary depending on the objective of the study. For mapping purposes, units less than $1 \mathrm{~m}$ in thickness must be considered as lenses or layers within a larger facies unit (Updike, 1986; Updike and Carpenter, 1986). By contrast, a laboratory geotechnical study of the facies, such as the present report, must isolate a finite suite of undisturbed samples representative of those defined facies. The facies which have been differentiated as distinct units at both scales are:

\footnotetext{
${ }^{3}$ This stratigraphic unit was originally named the Bootlegger Cove Clay by Miller and Dobrovolny (1959) for typical sections exposed at Bootlegger Cove in Anchorage. Because the unit varies greatly in composition and because clay is commonly a secondary constituent, Updike and others (1982) have renamed the unit the Bootlegger Cove Formation.
} 
Facies F.I Clay with very minor amounts of silt.

Facies F.II Silty clay and (or) clayey silt.

Facies F.III Silty clay and (or) clayey silt, sensitive.

Facies F.IV Silty clay and clayey silt, with silt and fine sand lenses.

Facies F.V Silty clay and (or) clayey silt, with random stones.

Facies F.VI Dense silty fine sand, with silt and clay layers.

Facies F.VII Fine to medium sand, with traces of silt and gravel.

In addition to the geologic distinction of the facies based on sedimentologic criteria, each facies may be further defined by statistical analyses of geotechnical characteristics, including natural moisture content, Atterberg limits, plasticity index, liquidity index, standard penetration test, undrained shear strength, unconfined compressive strength, and sensitivity ratio. The composite of the geologic and geotechnical criteria defines each of the seven engineering geologic facies, as discussed in detail by Updike (1986).

\section{GEOLOGIC HISTORY OF THE SITE}

The site at which the undisturbed samples of the Bootlegger Cove Formation were collected was found to be geologically typical of the 60 city blocks that form the metropolitan "core area" of Anchorage (fig. 3). The formation here is overlain by $8-13 \mathrm{~m}$ of gravelly sand and sandy gravel which were deposited over the superface of the Bootlegger Cove Formation as a glacial outwash plain that extended southwest from the Eagle River area. These stratified glaciofluvial sediments predominantly consist of medium to coarse sands in the lower half of the unit and grade upward to coarser sandy gravels with interbeds of sand and silt.

The distribution of boreholes at the site is shown in figure 4. The stratigraphic logs from these holes have been assessed on the basis of the engineering geologic facies criteria, and geologic cross sections of the site have been constructed (figs. 5, 6).

Of the several boreholes drilled at the site, only hole 6 , which reached a depth of $65 \mathrm{~m}$, penetrated the base of the formation. This hole and sites previously drilled nearby indicate that the total thickness of the formation generally exceeds $40 \mathrm{~m}$. This thickness approaches the maximum formational thicknesses recorded elsewhere in the city, which suggests that the site is situated toward the center of the primary Bootlegger Cove Formation depositional basin. The logs of the deep boreholes indicate that stratified sandy gravel and silty gravelly sand of good aquifer quality were encountered below the base of the formation. Such deposits are typical of highenergy, glaciofluvial sedimentation. Other deep boreholes

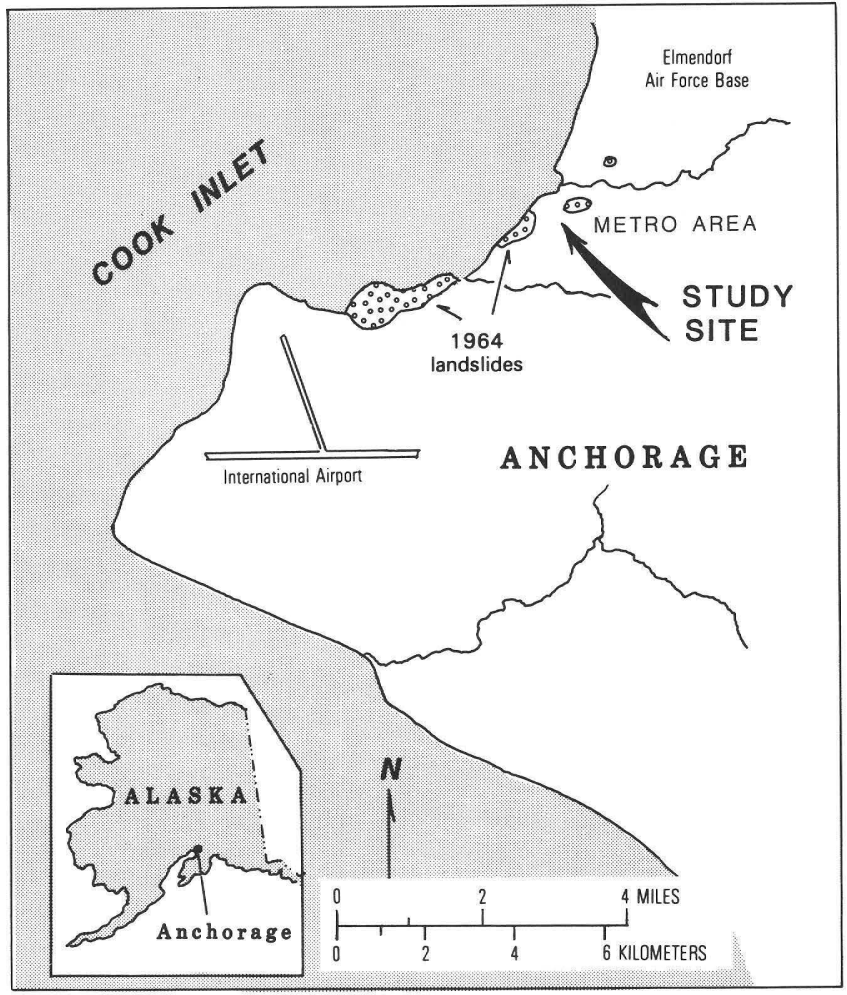

Figure 3. Generalized map showing the location of the sample site in Anchorage. The site is not more specifically located to maintain confidentiality of the land owner.

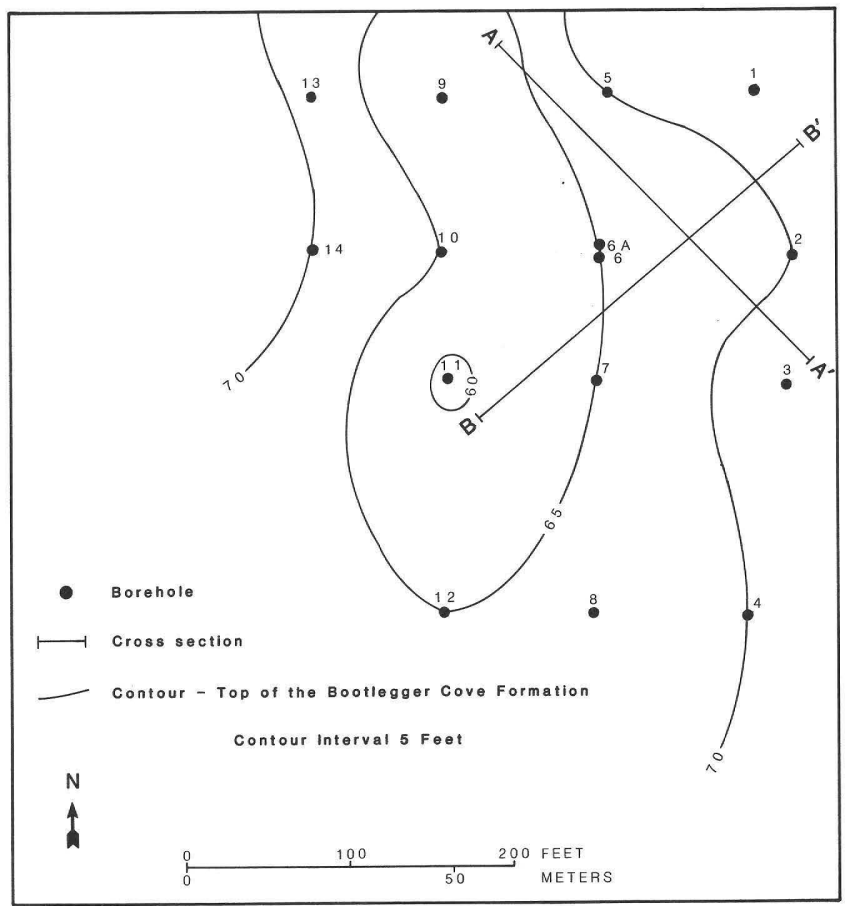

Figure 4. Map showing the location of boreholes and crosssection lines at the investigation site. Contours show elevations of the top of the Bootlegger Cove Formation in feet above mean sea level. The borehole data has been projected to the section line. 


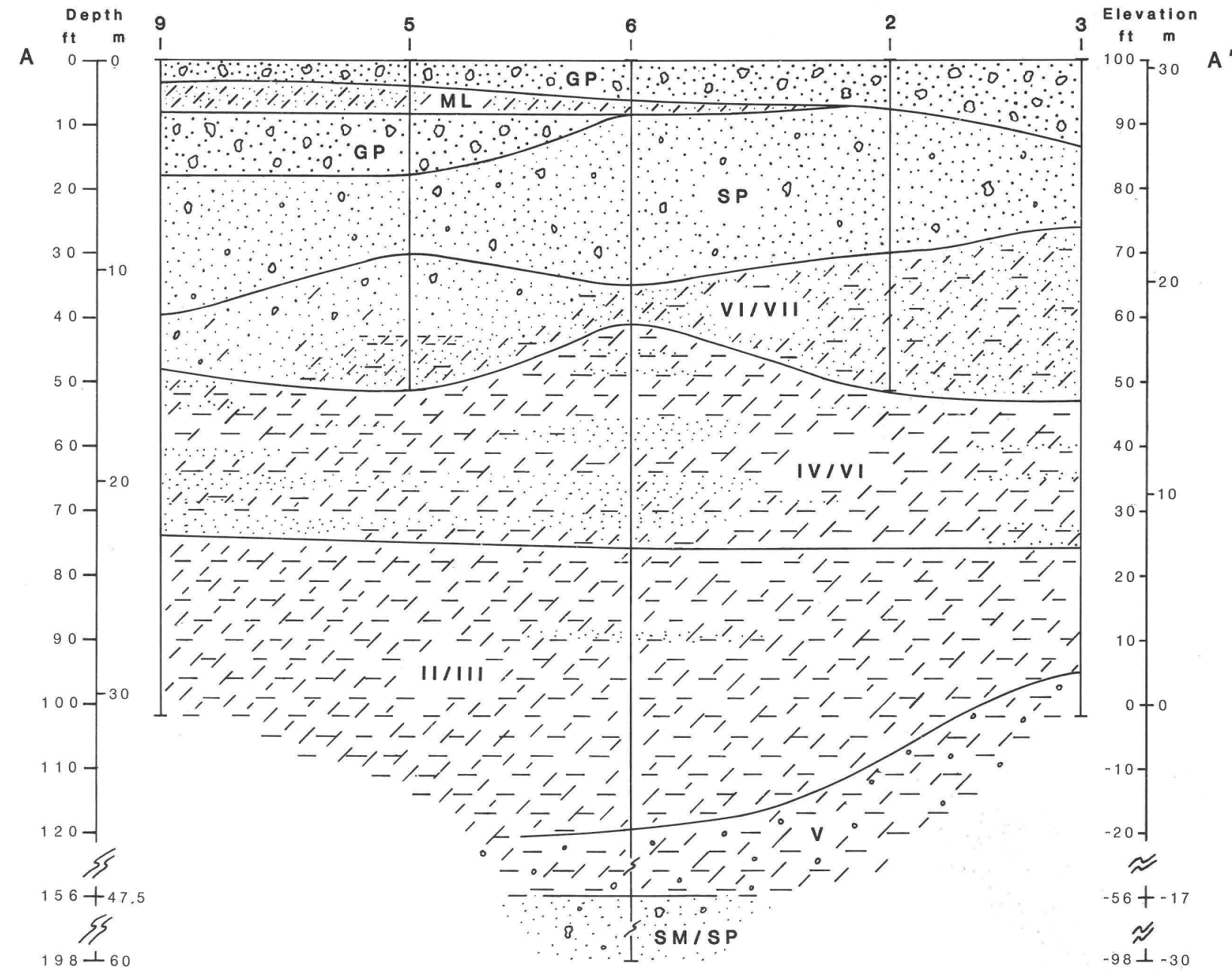

Figure 5. Geologic cross section along line $A-A^{\prime}$; location shown on figure 4. Symbols: $G P=\operatorname{sandy}$ gravel; $M L=$ inorganic silt and very fine sand; $\mathrm{SM}=$ silty sand; $\mathrm{SP}=$ gravelly sand; Roman numerals are facies of the Bootlegger Cove Formation. The borehole data have been projected to the section line.

in the downtown area indicate that the sand and gravel are underlain by a compact stony silt (diamicton) which is believed to be a glacial till.

Based upon stratigraphic correlations, we have interpreted the following history for the site:

(1) During late Knik or early Naptowne time (20,000 years B.P.), a glacier advanced across what is now downtown Anchorage and deposited till and glaciofluvial sediments over a preexisting glacial topography of Knik age. At present, these glacial sediments are at depths greater than about $60 \mathrm{~m}$ at the site and include the overconsolidated bouldery silts and confined aquifers (sandy gravels) that are commonly encountered in deep boreholes.

(2) Subsequently, ice retreated entirely out of the area and a period of weathering and erosion ensued until about 18,000 years B.P. when ice readvanced into the region. However, in contrast to the previous glaciation, during this episode ice did not enter the present-day downtown area but instead bordered the area to the west and north. These late Naptowne glaciers fronted in a marine or brackish-water basin bounded by the ice and the Chugach Mountains. Glaciodeltaic fans that extended away from these glaciers and into the basin deposited coarse gravels that grade basinward to dominantly sands and silts. Within the deep, quiet part of the basin, silts and clays accumulated with discontinuous sand lenses. These glaciodeltaic fan deposits, which prograde to glaciolacustrine silts and clays (as occur at the study site), are of late Naptowne age and compose the Bootlegger Cove Formation. The clayey silts with random stones (Facies F.V) that were encountered in the lower parts of the site boreholes represent the early sedimentation of this period, with ice-rafted dropstones being accumulated in a dominantly suspended load 


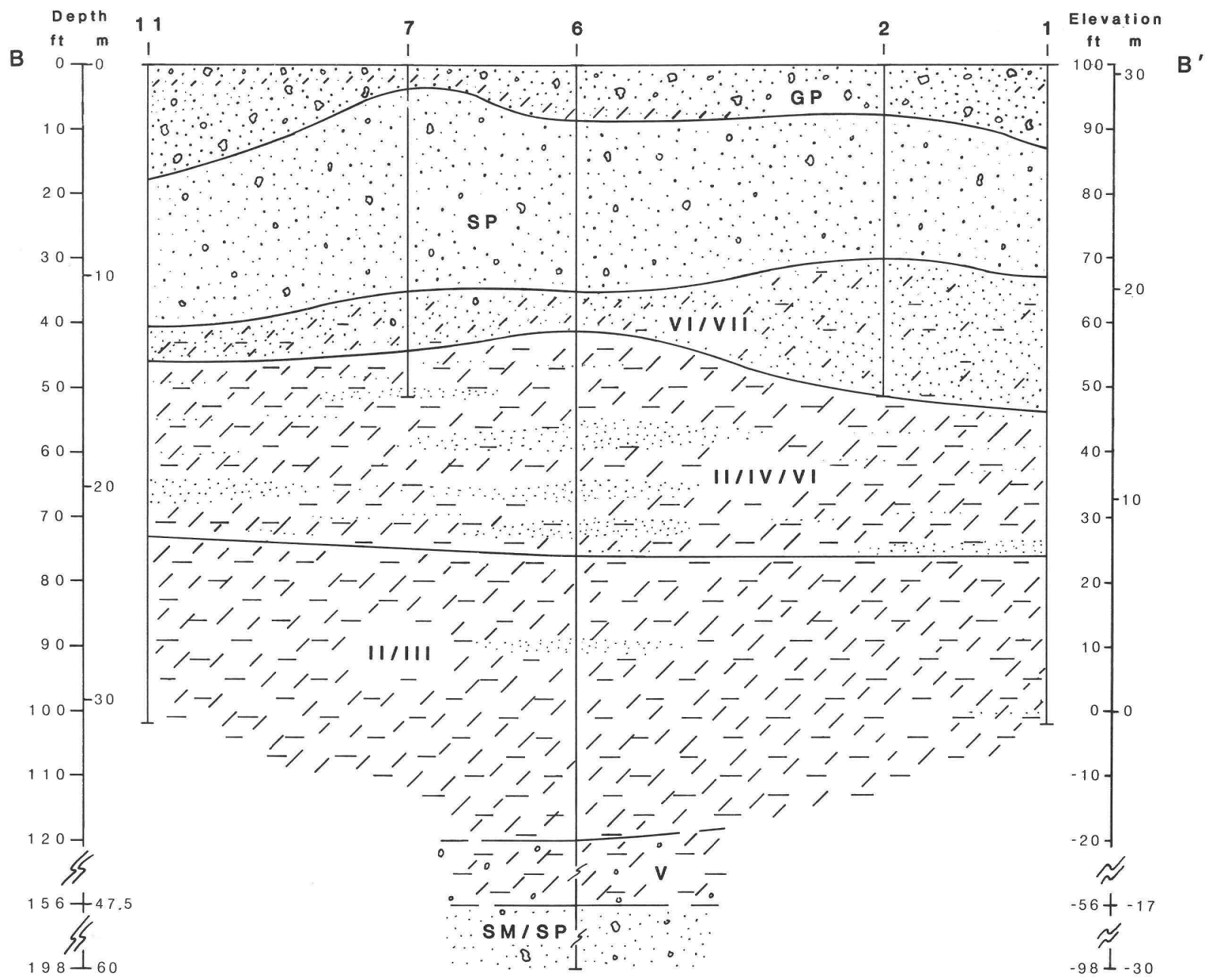

Figure 6. Geologic cross section along line $B-B^{\prime}$; location shown on figure 4. Symbols: $G P=$ sandy gravel; $S M=$ silty sand; $\mathrm{SP}=$ gravelly sand; Roman numerals are facies of the Bootlegger Cove Formation. The borehole data have been projected to the section line.

deposition. The fluctuations indicated by sedimentation of the Facies F.I to F.IV above Facies F.V record a stabilization and stagnation of the nearby ice front that resulted in quiet-water silt and clay accumulation with occasional influxes of sand (F.VI and F.VII). These subtle variations in bedding texture and structure were a response to the relative position and continuity of ice margins and marine waters and to the resultant changes in sediment transport energy. There was a general trend toward shallower water environments, occasionally even subaerial, in the later stages of Bootlegger Cove Formation deposition, as indicated by increasing presence of F.VI and F.VII. The final phase of deposition is marked by total dominance of fine to medium wellsorted sands (F.VII) which probably signifies the draining of the basin and tidal flat sedimentation.
(3) Either as a stillstand in the retreat of the glaciers described above or as a subsequent readvance, during latest Naptowne time a glacier from the north reached the present area of Elmendorf Air Force Base, and glaciofluvial sediments were deposited southward across the Bootlegger Cove Formation. This occurred at 10,00012,000 years B.P. and resulted in the brown sandy gravels that were recorded in the upper $8-13 \mathrm{~m}$ of the boreholes at the site.

(4) During the Holocene (last 10,000 years) the region has been subjected to vertical elevation adjustments in response to isostatic rebound and tectonics, juxtaposed against fluctuations in sea level. This has resulted in the development of erosional bluffs along Cook Inlet and along streams (for example, Ship Creek) that drain into the inlet. Scarp retreat due to mass movement along these bluffs has been ongoing for several hundred years and is gradually 
progressing toward the project site. Consolidation and salt leaching within the stratigraphic column has been enhanced by the gradual uplift of the soils with respect to sea level. There is no geologic evidence to suggest that the Bootlegger Cove Formation has been overridden by ice since it was deposited, nor that during the Holocene it was previously buried under a significantly thicker sediment cover than at present. Further, there is no evidence to imply that the soil sequence below the uppermost $15 \mathrm{~m}$ has ever been other than saturated and nonfrozen.

\section{STATIC ENGINEERING CHARACTERIZATION OF THE SITE}

\section{Field Sampling and Logging}

At each borehole location (fig. 4) standard splitspoon samples were collected by Cole at 5 -ft intervals to characterize the soils being penetrated by the hollow stem auger; characteristics such as texture, relative density, and relative moisture content were described. Standard penetration testing (SPT), in accordance with ASTM standard procedure D1586-67, was performed at each sample depth. Where test samples were desired,thin-walled, 3-inch $(7.6 \mathrm{~cm})$ diameter Shelby tube samplers of 2.5- and 5.0-ft $(0.75$ and $1.50 \mathrm{~m})$ lengths were slowly pushed into the undisturbed soil below the hollow stem auger casing. These Shelby tubes were transported directly from the drill site to the DOWL geotechnical lab where extraction of the samples proceeded within 48 hours of arrival. Each extracted sample was sketched, visually described, and characterized by penetrometer tests, torvane, natural moisture content, and Atterberg limits. During this phase, samples were classified, separated, and sealed for advanced static and dynamic testing.

Four phases of advanced laboratory testing followed the indices characterization of the borehole samples. These tests, and the facilities where they were performed, are: static triaxial compression (DOWL and UCLA), consolidation (DOWL), resonant column (Harding and Lawson Engineers, Inc., Novato, Calif.), and cyclic triaxial compression (UCLA). The results of the resonant column testing have been reported elsewhere (Updike and others, 1982). The results of the static as well as the dynamic testing programs are presented in this report.

\section{DYNAMIC LABORATORY TESTING PROGRAM}

Ten undisturbed samples (each approximately 8 inch [20 cm] in length) of the Bootlegger Cove Formation were selected from the cores extracted from thin-wall Shelby tube samplers. The samples consisted of:

CT-1 Facies F.IV. Clayey silt, with some fine silty sand layers; depth $84 \mathrm{ft}(25.6 \mathrm{~m})$, test hole 3 .

CT-2 Facies F.II. Silty clay, uniform texture, moderately firm; depth $91 \mathrm{ft}(27.8 \mathrm{~m})$, test hole 3 .

CT-3 Facies F.III. Silty clay, sensitive, uniform texture, layered; depth $96.5 \mathrm{ft}(29.4 \mathrm{~m})$, test hole 9.

CT-4 Facies F.IV. Clayey silt, with some fine silty sand layers; depth $80 \mathrm{ft}(24.4 \mathrm{~m})$, test hole 6 .

CT-5 Facies F.IV. Clayey silt, with some fine silty sand layers; depth $81 \mathrm{ft}(24.7 \mathrm{~m})$, test hole 7 .

CT-6 Facies F.IV. Clayey silt, with fine sand seams; depth $83.5 \mathrm{ft}(25.5 \mathrm{~m})$, test hole 6 .

CT-7 Facies F.IV. Clayey silt, with fine sand seams; depth $84.5 \mathrm{ft}(25.8 \mathrm{~m})$, test hole 6 .

CT-8 Facies F.II. Silty clay, uniform texture, bedded, medium soft; depth $87 \mathrm{ft}(26.5 \mathrm{~m})$, test hole 6.

CT-9 Facies F.II. Silty clay, uniform texture, bedded, medium soft; depth $87 \mathrm{ft}(26.5 \mathrm{~m})$, test hole 6.

RC-6 Facies F.II. Clayey silt, uniform texture, massive; depth $81 \mathrm{ft}(24.7 \mathrm{~m})$, test hole 9.

After the samples had been selected and catalogued they were sealed and hand-carried by Updike to the University of California-Los Angeles Soils Mechanics Laboratory for testing. The testing program was supervised by Lade. Standard soil indices tests (torvane, grain-size distribution, moisture content, density, and Atterberg limits) were performed on each sample in order to relate the dynamic properties of the facies obtained through advanced tests with the routinely obtained standard soil indices. Each sample was cut into halves; one half was used for static strength tests and the other half was used for cyclic loading tests. The testing program and the objectives for each series of tests for the ten samples are given below:

(1) A series of ten static triaxial compression tests were performed on intact specimens to establish the unconsolidated-undrained (UU) stress-strain behavior and shear strength of the soil. The specimens were then remolded and another series of static triaxial tests were executed to define the remolded UU shear strength and estimate the sensitivity of the soils.

(2) A series of ten triaxial compression tests with pore pressure measurements were performed on the remolded specimens to define the remolded isotropically consolidated-undrained (ICU) stress-strain behavior and shear strength of the soil in order to assess the postfailure consolidation of zones within the deposit which may have failed during previous earthquakes. 
(3) A series of ten stress-controlled cyclic triaxial tests were conducted on intact specimens, which were initially consolidated at overconsolidation stress ratios of $1.0,1.5$, and 2.0 and tested at the appropriate cyclic stress ratios, to establish the dynamic shear moduli, damping ratios, and number of cycles to cause various amounts of strain.

(4) A series of ten stress-controlled cyclic triaxial tests on remolded specimens of item 3 , which were initially consolidated at overconsolidation stress ratios of $1.0,1.5$, and 2.0, were conducted at appropriate cyclic stress ratios to establish the dynamic shear moduli, damping ratios, and number of cycles to cause various amounts of strain.

\section{Unconsolidated-Undrained Tests}

\section{Equipment}

The testing equipment used for the UU tests is shown in figure 7. It consists of a triaxial cell placed in a 5-ton Wykeham Farrance ${ }^{4}$ loading machine. A confining pressure is applied in the triaxial cell by air pressure, which is regulated and measured as shown on the left side of figure 7. A load cell, mounted below the cross bar on the loading machine, is used to measure the vertical deviator load that is applied to the triaxial specimen. The electrical signal from the load cell is measured by the BLH Strain Indicator shown on the right side of figure 7. A dial gauge is employed to measure the vertical deformation of the specimen.

\section{Testing Procedure}

The intact soil was trimmed to produce a final cylindrical specimen with a diameter of 1.40 inches $(3.57 \mathrm{~cm})$ and a height of $3.00-3.50$ inches $(7.62-8.89 \mathrm{~cm})$ for UU testing. The specimen was inspected, and a sketch with location and geometry of sedimentary laminae was drawn. The specimen was measured and weighed for determination of wet density. The specimen was then placed between a lucite cap and base, and two rubber membranes, each 0.002 inches $(0.005 \mathrm{~cm})$ thick, were rolled up around it. A layer of high-vacuum silicone grease was smeared on the inner membrane before the outer membrane was rolled up. Two O-rings were used

\footnotetext{
${ }^{4}$ Any use of trade names in this report is for descriptive purposes only and does not imply endorsement by the U.S. Geological Survey.
}

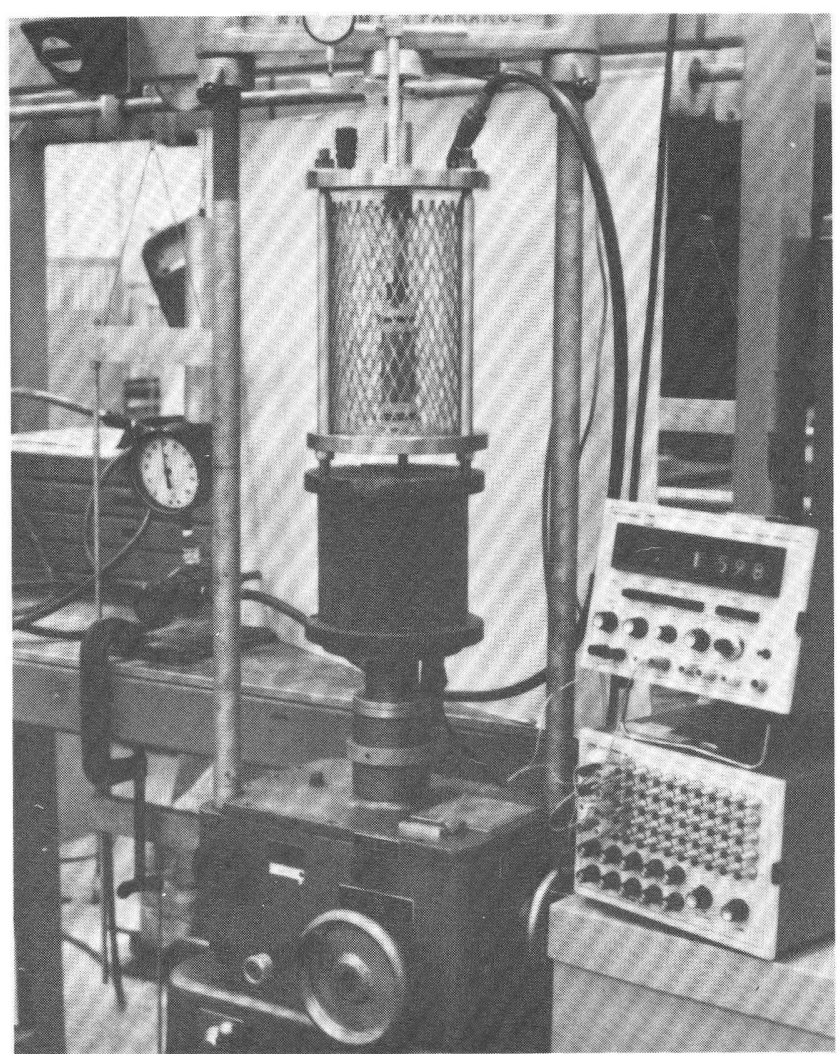

Figure 7. Triaxial testing equipment used for the unconsolidated-undrained static tests.

on each end to seal the membranes to the cap and base. The specimen was then placed in the triaxial cell, and a confining pressure of $50 \mathrm{psi}\left(3.52 \mathrm{~kg} / \mathrm{cm}^{2}\right)$ was applied by compressed air. The specimen was sheared at a constant rate of deformation of 0.020 inches/minute $(0.050 \mathrm{~cm} / \mathrm{minute})$, which corresponds to a strain rate of 0.57 percent $/$ minute for a 3.50 -inch $(8.89 \mathrm{~cm})$ specimen and $0.67 \mathrm{percent} / \mathrm{minute}$ for a 3.00 -inch $(7.62 \mathrm{~cm}) \mathrm{spec}$ imen. Measurements of load and deformation were taken at appropriate intervals throughout the test. At the end of each test, the triaxial cell was disassembled and the membranes were carefully removed to inspect the final shape of the specimen, to locate shear planes (recorded on a sketch), and to take a photograph of the failed specimen.

To perform a UU test on remolded soil, the previously intact specimen was mixed with part of the rough trimmings and thoroughly remolded. A cylindrical specimen was trimmed from the remolded soil, measured and weighed, and placed between the cap and base. The remolded specimen was tested under UU conditions without membranes and without confining pressure. The testing procedure for the remolded specimen was otherwise similar to that described above for the intact specimen. 
In addition to the ten UU tests on remolded soil performed without confining pressure, for comparative purposes, one UU test on remolded soil was performed on sample CT-8 (F.II) with a confining pressure of 50 psi $\left(3.52 \mathrm{~kg} / \mathrm{cm}^{2}\right)$. For this specimen the membranes were mounted around the soft remolded specimen using a vacuum jacket.

\section{Consolidated-Undrained Tests}

\section{Equipment}

The testing equipment used for consolidatedundrained (CU) tests is shown in figure 8. It consists of a triaxial cell placed in a 5-ton Wykeham Farrance loading machine. The cell water is pressurized by regulated air pressure in a separate lucite cylinder connected with the cell. This arrangement is used to avoid air penetration through the specimen membranes, thereby maintaining a high degree of saturation of the specimen. The drainage line from the triaxial specimen is connected to a volume change and pore pressure measuring device shown at the right in figure 8 . A back pressure can be applied in the specimen through this device. A load cell, mounted below the cross bar on the loading machine, is used to measure the vertical deviator load applied to the specimen. An LVDT (linear variable displacement transducer) is employed to measure the vertical deformation of the specimen. The electrical signals from the load cell, the pore pressure transducer, and the LVDT were measured and recorded by the Digitec 1000 datalogger shown at the left in figure 8 .

\section{Testing Procedure}

The CU tests were performed only on remolded specimens because the limited intact sample material that was available needed to be conserved for the dynamic tests. The remolded specimen previously tested under UU conditions was again mixed with part of the rough trimmings and thoroughly remolded. A cylindrical specimen with a diameter of 1.40 inches $(3.57 \mathrm{~cm})$ and a height of $3.00-3.50$ inches $(7.62-8.89 \mathrm{~cm})$ was trimmed from the remolded soil, measured, and weighed. A water-saturated carborundum filter stone was fitted on the stainless steel base to provide drainage for the CU specimen, which was placed on the filter stone. A lucite cap was placed directly on top of the specimen. Vertically slotted filter paper was wrapped around the specimen to provide radial drainage. The filter paper was then wetted to make it cling to the specimen. The O-ring at the end of the inner rubber

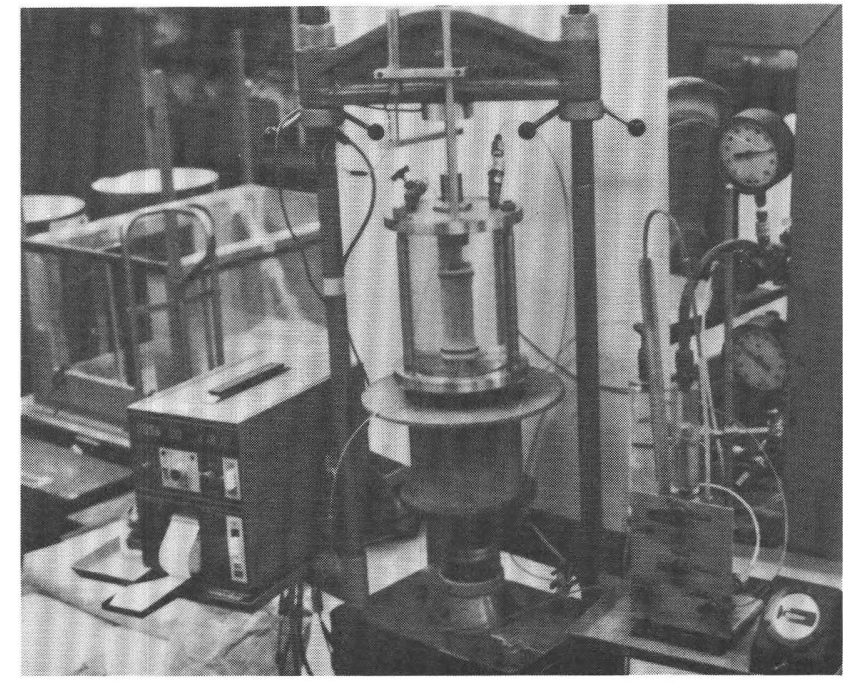

Figure 8. Triaxial testing equipment used for the isotropically consolidated-undrained static tests.

membrane was cut off to avoid penetration into the soft remolded soil. Without this O-ring and with the additional strength provided by the filter paper drains, it was possible to roll the inner membrane up around the specimen, while avoiding severe indentation in the specimen. A thin layer of high-vacuum silicone grease was smeared on the inner membrane before the outer membrane was rolled up. Two O-rings were used on each end to seal the membranes to the cap and base. After having assembled the specimen on the bottom plate of the triaxial cell, the cell wall and the top plate were installed, the cell was filled with de-aired water, and a confining pressure was applied.

With the drainage line connected to the volume change and pore pressure measuring device and with the drainage valve closed, the desired cell pressure of $80 \mathrm{psi}$ $\left(5.63 \mathrm{~kg} / \mathrm{cm}^{2}\right)$ and back pressure of $30 \mathrm{psi}\left(2.11 \mathrm{~kg} / \mathrm{cm}^{2}\right)$ were applied. An effective isotropic confining pressure (cell pressure minus back pressure) of $50 \mathrm{psi}\left(3.52 \mathrm{~kg} / \mathrm{cm}^{2}\right)$ was employed in all tests. By opening the drainage valve, the specimen was allowed to consolidate isotropically; in other words, it was an isotropically consolidated-undrained (ICU) test. Measurements of volume change, vertical deformation, and time were taken to produce a consolidationtime curve. The information from this curve was used to calculate an allowable vertical strain rate for the undrained shearing of the specimen. Because a datalogger was employed for the shearing phase of the test, it was possible to further reduce the vertical strain rate, thus insuring a high degree of pore water pressure equalization inside the specimen. A deformation rate of 0.00024 inches/minute $(0.0006 \mathrm{~cm} /$ minute $)$ was used in all tests except those on samples CT-1 (0.00016 inches/minute; $0.0004 \mathrm{~cm} /$ minute) and CT-6 (0.00048 inches/minute; $0.0012 \mathrm{~cm} /$ minute) . 
With maximum vertical strains between 22 percent and 36 percent, each test lasted from 1.5 to 3 days.

The value of pore pressure parameter $B$ (measured pore pressure increase/applied confining pressure increase) was measured immediately before shearing to obtain an indication of the degree of saturation of the specimen. During shearing, the vertical load, vertical deformation, and pore water pressure were measured at appropriate time intervals and recorded by the datalogger. At the end of each test the triaxial cell was disassembled and the failed specimen was photographed. The specimen was then quartered by vertical cuts, and one quarter was used for water content determination. The remaining parts were stored with the trimmings for determination of liquid and plastic limits.

\section{Cyclic Loading Tests}

\section{Equipment}

The testing equipment used for cyclic loading tests is shown in figure 9. It consists of a triaxial cell placed in a cyclic loading machine. The cell water was pressurized by regulated air pressure in a separate lucite cylinder connected with the cell through a 1/4-inch nylon tube. This arrangement was similar to that used for the ICU tests. The drainage line from the triaxial specimen was connected to a volume change and pore pressure measuring device (figure 9). A back pressure can be applied in the specimen through this device. A load cell, mounted below the double-acting piston on the cross bar of the cyclic loading frame, was used to measure the vertical cyclic load applied to the triaxial specimen. Static and cyclic air pressure was applied in the double-acting piston from the Pneumatic Sinusoidal Loader. An LVDT was employed to measure the vertical deformation of the specimen. The electrical signals from the load cell, the pore pressure transducer, and the LVDT were measured and recorded versus time on a 4-channel Sanborn strip-chart recorder. A Houston $2000 \mathrm{X}-\mathrm{Y}$ recorder was used for recording cyclic deviator stress versus vertical strain.

\section{Testing Procedure}

Cyclic loading tests were performed on intact and remolded specimens. The cylindrical specimen with a diameter of 1.40 inches $(3.57 \mathrm{~cm})$ and a height of $3.00-3.50$ inches $(7.62-8.89 \mathrm{~cm})$ was measured and weighed. A water-saturated carborundum filter stone was placed on the stainless steel base to provide drainage for the specimen during the initial consolidation. The specimen was placed between the filter stone and a lucite cap.

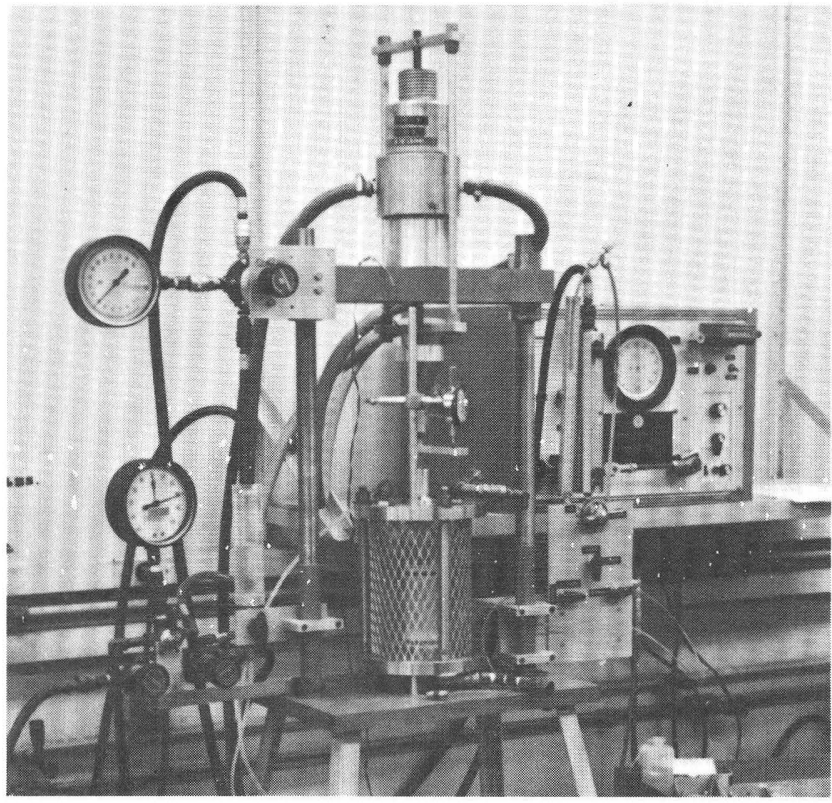

Figure 9. Cyclic triaxial testing equipment used for the cyclic loading tests.

Filter paper slotted at $45 \times$ was wrapped around the cyclic loading specimen to provide radial drainage. The filter paper was then wetted to make it cling to the specimen. Two thin rubber membranes were rolled up around the cylindrical specimen. A layer of high-vacuum silicone grease was smeared on the inner membrane before the outer membrane was rolled up. Two O-rings were used on each end to seal the membranes to the cap and base.

After having assembled the specimen on the bottom plate of the triaxial cell, the cell wall and the top plate were installed. De-aired water was introduced to fill the cell completely, and the cell water was pressurized. After consolidation and immediately before the cyclic loading, the water level in the triaxial cell was reduced to about one inch above the cap of the specimen, thus allowing vertical cyclic loading of the specimen without inducing cyclic cell pressures. The triaxial cell with the specimen was then mounted in the cyclic loading frame with the bottom plate rigidly attached to the table top, and the loading rod was attached to the load cell fixed to the end of the double-acting piston. With the drainage line connected to the volume change and pore pressure measuring device, the desired cell pressure of $80 \mathrm{psi}\left(5.63 \mathrm{~kg} / \mathrm{cm}^{2}\right)$ and back pressure of $30 \mathrm{psi}\left(2.11 \mathrm{~kg} / \mathrm{cm}^{2}\right)$ were applied. The uplift pressure on the rod was counterbalanced by an adjustment of the pressure on one side of the doubleacting piston, thus insuring isotropic consolidation pressures on the specimen. An effective isotropic confining pressure (cell pressure minus back pressure) of $50 \mathrm{psi}$ $\left(3.52 \mathrm{~kg} / \mathrm{cm}^{2}\right)$ was employed for the initial consolidation stage, for all cyclic loading tests. 
By opening the drainage valve, the specimen was allowed to consolidate. Measurement of volume change, vertical deformation, and time were taken to produce a consolidation-time curve. This curve was plotted and traced to insure that full primary consolidation had taken place before cyclic loading of the specimen was initiated.

For specimens with final consolidation stress ratios of $K_{c}=1.5$ and 2.0, the initial consolidation $\left(K_{c}=1.0\right)$ was first achieved to let the specimen gain some strength before the deviatoric consolidation stress was applied. This was done to avoid static failure due to pore pressure increase of the specimens upon application of the deviatoric consolidation stress. This stress was applied in one step to obtain a consolidation stress ratio of $K_{c}=1.5$ and in two steps to obtain $K_{c}=2.0$. Full consolidation was achieved for each step before the next step was applied.

Before the triaxial cell with the specimen was mounted in the cyclic loading frame, the sinusoidal cyclic load to be applied to the specimen was determined relative to the previously determined static undrained shear strength. The equipment was adjusted to provide that calculated cyclic load. The cyclic load was also recorded on the strip chart by the Sanborn Recorder before the actual test was performed, thus providing a calibration for possible further changes in cyclic load after installing the specimen in the cyclic loading frame. The actual cyclic deviator stress applied to the specimen after consolidation was calculated after the test was completed.

The deformation of the specimen during cyclic loading was measured with an LVDT, which was individually calibrated for each test (due to different specimen heights) to produce direct measurements of strain on the Sanborn Recorder and on the X-Y Recorder. Pore pressures were also calibrated and recorded on the strip chart by the Sanborn Recorder. The X-Y Recorder was used to obtain stress-strain relationships throughout or at a selected number of applied load cycles for determination of shear moduli and damping ratios. At the end of each test, the triaxial cell was disassembled and the failed specimen was photographed.

To perform a cyclic loading test on remolded soil, the previously intact specimen was thoroughly remolded and prepared in the same manner as the remolded UU specimens. The testing procedure for the remolded specimens was also similar to that used for the intact specimens.

In an attempt to get a direct comparison between properties of the intact specimens and those of the remolded specimens, the same cyclic deviator load was applied in both cases. However, because the intact specimens consolidated less than the remolded specimens, the cyclic deviator stress applied to the former was slightly lower than that applied to the latter.

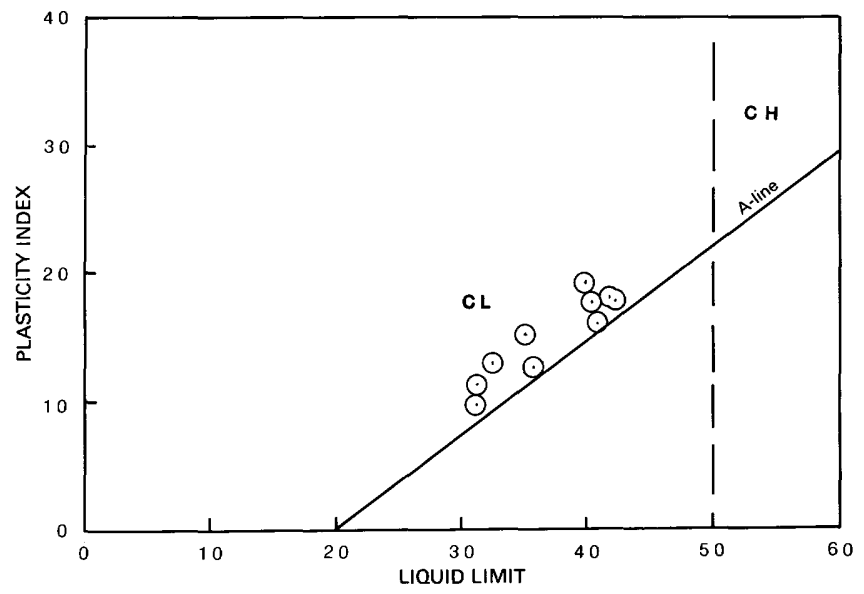

Figure 10. Plasticity chart for samples of the Bootlegger Cove Formation tested in this study.

Following the cyclic test on the remolded specimen, the triaxial cell was disassembled, the failed specimen was photographed, and water content was determined.

\section{RESULTS OF LABORATORY TESTING}

\section{Soil Index Tests}

The results of the Atterberg limit and hydrometer tests are summarized in table 1. The Atterberg limit tests were performed on soil from the static section of the samples. The results of these tests are plotted on the plasticity chart (fig. 10). All samples have low plasticity and are inorganic (above the A-line); thus they correspond to a unified classification of CL.

The grain-size distributions were determined by hydrometer tests on soil from the cyclic section of the samples. A standard value of the specific gravity of $G_{s}=2.782$ was used for all calculations related to these tests. The median grain diameter $\left(D_{50}\right)$ and the percentage of clay, silt, and sand are given in table 1. Only one sample (CT-2) contained a measurable amount of sand (about 22 percent). The static section of sample CT-4 contained one pebble-sized grain. Activities for all samples, also listed in table 1 , were between 0.18 and 0.42 .

\section{Static Tests}

The results of the torvane tests and the UU tests on intact and remolded specimens are summarized in table 2. Also summarized in this table are the water contents, specimen geometries, wet densities, and calculated sensitivities. Detailed test results, including sketches of 
Table 1. Summary of Atterberg limit and hydrometer tests on the Bootlegger Cove Formation

[Particle size boundaries are: sand $/$ silt $=0.075 \mathrm{~mm}$; silt/clay $=0.002 \mathrm{~mm}$. See "GLOSSARY OF SYMBOLS USED" for definitions of symbols]

\begin{tabular}{lllllllllll}
\hline Sample & CT-1 & CT-2 & CT-3 & CT-4 & CT-5 & CT-6 & CT-7 & CT-8 & CT-9 & RC-6 \\
\hline Liquid 1imit
\end{tabular}

${ }^{1}$ Values determined from static sections of samples.

2 Values determined from cyclic sections of samples. 
Table 2. Summary of torvane and UU triaxial tests on intact and remolded specimens of the Bootlegger Cove Formation [nd, not determined. See "GLOSSARY OF SYMBOLS USED” for definitions of symbols]

\begin{tabular}{|c|c|c|c|c|c|c|c|c|c|c|}
\hline Samp $1 e$ & $\mathrm{CT}-1$ & $\mathrm{CT}-2$ & $\mathrm{CT}-3$ & CT -4 & $\mathrm{CT}-5$ & CT $-6^{4}$ & С T-7 & $C T-8^{5}$ & СТ-9 & $\mathrm{RC}-6$ \\
\hline $\begin{array}{l}K_{c}=\sigma_{1 c} / \sigma_{3 c} \text { before cyclic } \ldots \\
\text { loading. }\end{array}$ & 1.0 & 1.5 & 1.5 & 2.0 & 1.0 & 1.0 & 2.0 & 1.5 & 2.0 & 1.0 \\
\hline Initial length of sample $(\mathrm{cm})$ & 21.5 & 23.0 & 18.0 & 21.5 & 23.0 & 19.0 & 19.5 & 19.0 & 15.0 & 21.0 \\
\hline \multicolumn{11}{|l|}{ Torvane tests, static section ${ }^{1}$} \\
\hline $\mathrm{s}_{\mathrm{u}}($ intact $)\left(\mathrm{kg} / \mathrm{cm}^{2}\right) \ldots \ldots$ & nd & 0.52 & 0.64 & 0.51 & nd & $\begin{array}{l}0.86 \\
1.80\end{array}$ & 0.69 & 0.59 & 0.68 & 0.53 \\
\hline $\mathrm{s}_{\mathrm{u}}($ remolded $)\left(\mathrm{kg} / \mathrm{cm}^{2}\right) \ldots \ldots$ & nd & 0.07 & 0.12 & 0.08 & nd & $\begin{array}{l}0.18 \\
0.30\end{array}$ & 0.13 & 0.08 & 0.10 & 0.07 \\
\hline$s_{t} \ldots \ldots \cdots \cdots \cdots \cdots \cdots \cdots \cdots$ & nd & 7.4 & 5.3 & 6.4 & nd & $\begin{array}{l}4.8 \\
6.0\end{array}$ & 5.3 & 7.4 & 6.8 & 7.6 \\
\hline \multicolumn{11}{|l|}{ Torvane tests, cyclic section ${ }^{1}$} \\
\hline$s_{u}(i n t a c t)\left(\mathrm{kg} / \mathrm{cm}^{2}\right) \ldots \ldots$ & 0.44 & 0.48 & 0.61 & 0.49 & 0.56 & 0.91 & 0.82 & 0.56 & 0.83 & 0.60 \\
\hline $\mathrm{s}_{\mathrm{u}}(\mathrm{remolded})\left(\mathrm{kg} / \mathrm{cm}^{2}\right) \ldots \ldots$ & 0.07 & 0.07 & 0.08 & 0.07 & 0.08 & 0.19 & 0.07 & 0.08 & 0.08 & 0.09 \\
\hline$s_{t} \ldots \ldots \ldots \ldots \ldots \ldots \ldots \ldots$ & 6.3 & 6.8 & 7.6 & 7.0 & 7.0 & 4.7 & 11.7 & 7.0 & 10.4 & 6.7 \\
\hline \multicolumn{11}{|l|}{ vo triaxial tests, intact ${ }^{2}$} \\
\hline $\begin{array}{l}\text { w/c (outer } 0.5 \text { cm of } \ldots \ldots \ldots \\
\text { sample) }(\%) .\end{array}$ & 28.08 & 26.04 & 25.54 & 30.02 & 30.28 & 24.79 & 23.95 & 33.77 & 32.09 & 30.22 \\
\hline w/c (trimmings) $(\%) \ldots \ldots \ldots$ & 30.14 & 27.86 & 26.80 & 32.55 & 32.54 & 24.72 & 26.26 & 36.62 & 34.31 & 32.35 \\
\hline$A_{o}\left(c^{2}\right) \ldots \ldots \ldots \ldots \ldots \ldots$ & 9.931 & 9.931 & 9.931 & 9.931 & 9.931 & 9.931 & 9.931 & 9.931 & 9.931 & 9.931 \\
\hline $\mathrm{H}_{\mathrm{o}}(\mathrm{cm}) \ldots \ldots \ldots \ldots \ldots \ldots$ & 8.87 & 8.99 & 7.75 & 8.84 & 8.87 & 8.48 & 8.84 & 8.31 & 7.42 & 8.84 \\
\hline$v_{o}\left(\mathrm{~cm}^{3}\right) \ldots \ldots \ldots \ldots \ldots$ & 88.04 & 89.30 & 76.94 & 87.78 & 88.04 & 84.25 & 87.78 & 82.48 & 73.66 & 87.78 \\
\hline$\gamma_{\text {wet }}\left(\mathrm{g} / \mathrm{cm}^{3}\right) \ldots \ldots \ldots \ldots$ & 1.958 & 2.010 & 2.032 & 1.931 & 1.948 & 2.044 & 2.041 & 1.898 & 1.923 & 1.947 \\
\hline$s_{u}\left(k g / \mathrm{cm}^{2}\right) \ldots \ldots \ldots \ldots \ldots$ & 0.507 & 0.624 & 0.672 & 0.531 & 0.603 & $\begin{array}{l}1.189 \\
1.126\end{array}$ & 0.798 & 0.620 & 0.829 & 0.560 \\
\hline \multicolumn{11}{|l|}{ UU triaxial tests, remolded ${ }^{3}$} \\
\hline$w / c(t r i m m i n g s)(\%) \ldots \ldots \ldots$ & 28.95 & 27.19 & 26.61 & 32.31 & 32.37 & 23.72 & 25.39 & $\begin{array}{l}31.69 \\
31.36\end{array}$ & 33.74 & nd \\
\hline$A_{o}\left(c^{2}\right) \cdots \cdots \cdots \cdots \cdots \cdots$ & 9.931 & 9.931 & 9.931 & 9.931 & 9.931 & 9.931 & 9.931 & $\begin{array}{l}9.931 \\
9.931\end{array}$ & 9.931 & 9.931 \\
\hline $\mathrm{H}_{\mathrm{o}}(\mathrm{cm}) \ldots \ldots \ldots \ldots \ldots \ldots \ldots$ & 8.05 & 8.31 & 7.75 & 8.76 & 8.48 & 7.16 & 8.59 & $\begin{array}{l}7.11 \\
8.48\end{array}$ & 7.82 & 8.81 \\
\hline$v_{o}\left(c^{3}\right) \cdots \cdots \cdots \cdots \cdots \cdots$ & 79.97 & 82.48 & 76.94 & 87.03 & 84.26 & 71.13 & 85.26 & $\begin{array}{l}70.63 \\
84.25\end{array}$ & 77.69 & 87.53 \\
\hline$\gamma_{\text {wet }}\left(\mathrm{g} / \mathrm{cm}^{3}\right) \ldots \ldots \ldots \ldots \ldots$ & 1.960 & 2.012 & 2.036 & 1.958 & 1.915 & 2.050 & 2.048 & $\begin{array}{l}1.894 \\
1.966\end{array}$ & 1.914 & 1.955 \\
\hline $\mathrm{s}_{\mathrm{u}}\left(\mathrm{kg} / \mathrm{cm}^{2}\right) \ldots \ldots \ldots \ldots \ldots$ & 0.126 & 0.171 & 0.156 & 0.115 & 0.155 & 0.428 & 0.175 & $\begin{array}{l}0.128, \\
0.224\end{array}$ & 0.130 & 0.139 \\
\hline$s_{t}(U U$ Tests $) \ldots \cdots \cdots \cdots \cdots$ & 4.0 & 3.7 & 4.3 & 4.6 & 3.9 & $\begin{array}{l}2.8 \\
2.6\end{array}$ & 4.6 & $\begin{array}{l}4.8 \\
2.8\end{array}$ & 6.4 & 4.0 \\
\hline
\end{tabular}

\footnotetext{
${ }^{1}$ Average values are given for each of static and cyclic sections.

${ }^{2}$ Confining pressure $=3.52 \mathrm{~kg} / \mathrm{cm}^{2}(50 \mathrm{psi})$.

${ }^{3}$ Confining pressure $=0$.

${ }^{4}$ Sample cT-6 had a stiff layer over about half of the static section. Therefore, interpretation is in terms of two different heights.

${ }^{5}$ Remolded specimens tested with $\sigma_{3}=0$ and $\sigma_{3}=3.52 \mathrm{~kg} / \mathrm{cm}^{2}$, respectively.
}

specimens before and after failure, photographs of failed specimens, and stress-strain curves were recorded for later inspection and possible correlation studies.

The UU tests on intact specimens were performed with confining pressures of 50 psi $\left(3.52 \mathrm{~kg} / \mathrm{cm}^{2}\right)$ to simulate effective overburden pressure, whereas the tests on remolded specimens were performed as unconfined tests. One test on remolded soil (from sample CT-8) was performed with a confining pressure of 50 psi $\left(3.52 \mathrm{~kg} / \mathrm{cm}^{2}\right)$. The undrained shear strength from this 
test was substantially higher than that from the corresponding unconfined test which results in a correspondingly lower sensitivity number. Thus, the true sensitivities of tested samples may be somewhat lower than those listed in table 2 because the in-situ remolded soil is under a confining pressure.

The undrained shear strengths from the torvane tests on intact samples are comparable to those obtained from the UU tests on intact specimens. However, the remolded shear strengths from the torvane tests are lower than those obtained from the corresponding UU tests.

The undrained shear strengths from the UU tests are plotted versus water content and are compared with results of other tests in figure 11. Although a considerable amount of scatter appears to be present, the test results were actually clustered in groups consistent with the type of test (UU or ICU) and the condition of the soil (intact or remolded). The strength values from the UU tests on intact specimens are lower than those from the ICU tests on intact and remolded specimens. This is reasonable, because the effective consolidation pressure in the ICU tests is $50 \mathrm{psi}\left(3.52 \mathrm{~kg} / \mathrm{cm}^{2}\right)$ or higher. The effective confining pressures in the UU-tests are unknown but are smaller than $50 \mathrm{psi}$, which is the approximate effective overburden pressure in-situ.

The results of the ICU tests on remolded specimens are summarized in table 3. Summarized in this table are the water contents, specimen geometries, initial wet densities, vertical and volumetric strains due to consolidation, consolidation times, coefficients of consolidation, and all information related to failure at maximum effective stress ratio $\left(\sigma_{1}^{\prime} / \sigma^{\prime}\right)_{\max }$ and at maximum deviator stress $\left(\sigma_{1}-\sigma_{3}\right)_{\max }$. Detailed test results, including consolidation curves, stress-strain and pore pressure curves, effective stress-paths, and photographs of failed specimens, are available from the authors.

Figure 12 shows a plot of the results of triaxial ICU tests on remolded samples, on a p-q diagram. The data points give the values of effective normal stress, $p$, and

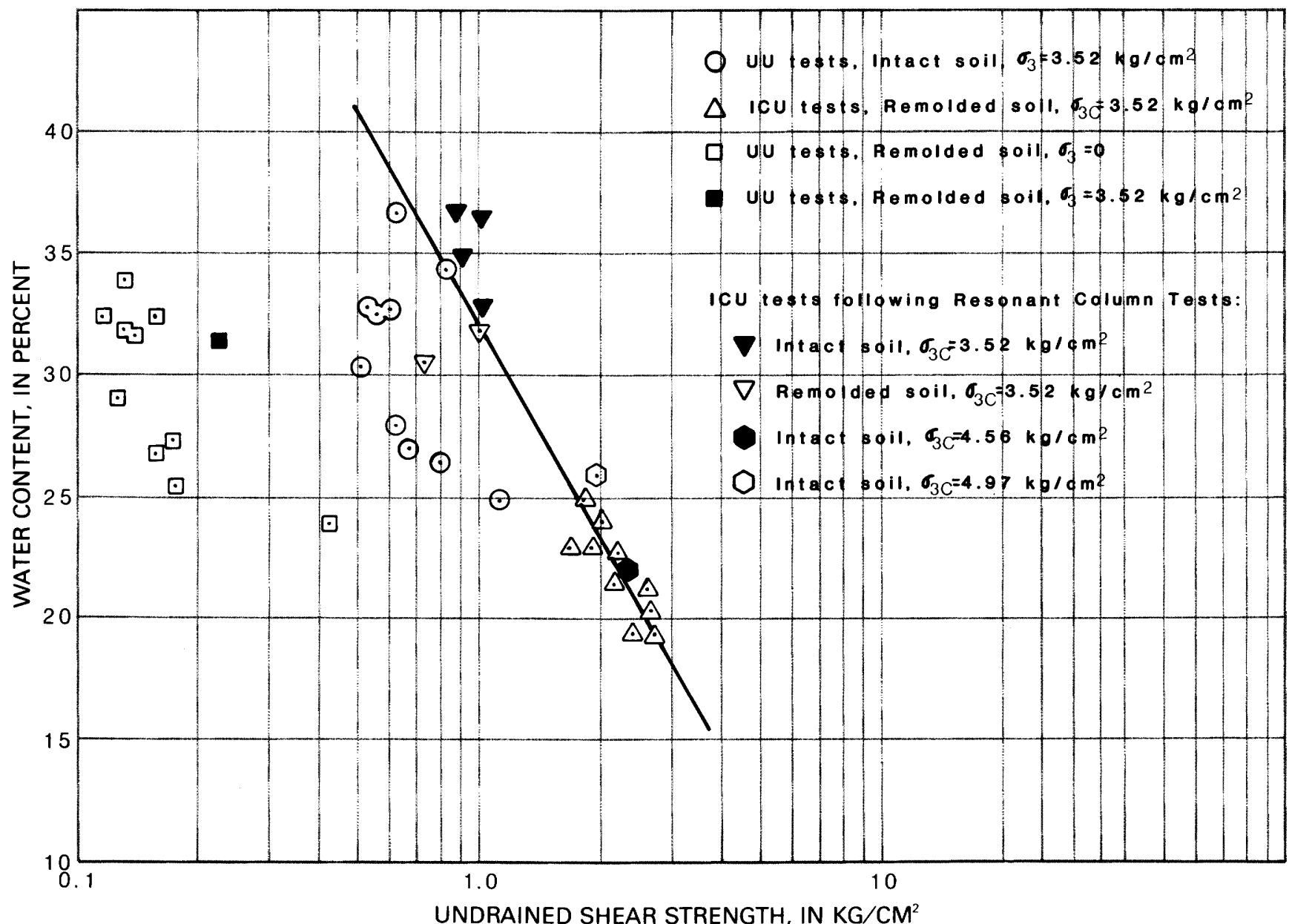

Figure 11. Undrained shear strength versus water content as derived from unconsolidated-undrained (UU) tests and isotropically consolidated-undrained (ICU) tests. Solid line indicates relationship for ICU tests, determined during resonant column testing program (see Updike and others, 1982). 
Table 3. Summary of ICU triaxial compression tests on remolded Bootlegger Cove Formation specimens [See "GLOSSARY OF SYMBOLS USED" for definitions of symbols]

\begin{tabular}{|c|c|c|c|c|c|c|c|c|c|c|}
\hline Sample & $\mathrm{CT}-1$ & $\mathrm{CT}-2$ & $\mathrm{CT}-3$ & $\mathrm{CT}-4$ & $\mathrm{CT}-5$ & $\mathrm{CT}-6$ & $\mathrm{CT}-7$ & $\mathrm{CT}-8$ & $\mathrm{CT}-9$ & $\mathrm{RC}-6$ \\
\hline \multicolumn{11}{|l|}{ Before consolidation } \\
\hline$w / c(t r i m m i n g s)(\%) \ldots \ldots$ & 27.61 & 26.34 & 25.79 & 31.18 & 30.18 & 23.78 & 25.17 & 33.49 & 31.60 & 30.79 \\
\hline$A_{o}\left(c m^{2}\right)^{1} \ldots \ldots \ldots \ldots \ldots$ & 9.931 & 9.931 & 9.931 & 9.931 & 9.931 & 9.931 & 9.931 & 9.931 & 9.931 & 9.931 \\
\hline $\mathrm{H}_{\mathrm{o}}(\mathrm{cm})^{1} \ldots \ldots \ldots \ldots \ldots$ & 7.823 & 8.179 & 8.814 & 8.763 & 8.255 & 6.858 & 8.484 & 8.788 & 8.788 & 8.204 \\
\hline$v_{o}\left(c^{3}\right) \ldots \ldots \ldots \ldots \ldots$ & 77.69 & 81.22 & 87.53 & 87.03 & 81.98 & 68.11 & 84.25 & 87.28 & 87.28 & 81.48 \\
\hline$\gamma_{\text {wet }}\left(\mathrm{g} / \mathrm{cm}^{3}\right) \ldots \ldots \ldots \ldots$ & 1.986 & 2.062 & 2.072 & 1.951 & 1.976 & 2.056 & 2.092 & 1.936 & 1.974 & 1.976 \\
\hline \multicolumn{11}{|l|}{ After consolidation } \\
\hline$\Delta v_{\text {consol }}\left(\mathrm{cm}^{3}\right) \ldots \ldots \ldots \cdots$ & 7.990 & 7.148 & 9.494 & 11.647 & 10.433 & 5.506 & 9.356 & 11.633 & 10.612 & 10.405 \\
\hline$\Delta \delta$ consol $(\mathrm{cm}) \ldots \ldots \cdots \cdots$ & 0.150 & 0.138 & 0.154 & 0.219 & 0.251 & 0.143 & 0.110 & 0.244 & 0.184 & 0.172 \\
\hline$\epsilon_{\epsilon_{\perp \operatorname{consol}}(\%)}(\%) \cdots \cdots \cdots$ & $\begin{array}{c}10.28 / \\
1.65\end{array}$ & $\begin{array}{l}8.80 / \\
1.70\end{array}$ & $\begin{array}{c}10.85 / \\
2.39\end{array}$ & $\begin{array}{c}13.38 / \\
3.04\end{array}$ & $\begin{array}{l}12.73 / \\
2.09\end{array}$ & $\begin{array}{l}8.08 / \\
1.24\end{array}$ & $\begin{array}{l}11.11 / \\
2.70\end{array}$ & $\begin{array}{l}13.33 / \\
2.03\end{array}$ & $\begin{array}{l}12.16 / \\
1.24\end{array}$ & $\begin{array}{l}12.77 / \\
2.03\end{array}$ \\
\hline$A_{c}\left(c^{2}\right)^{1} \ldots \ldots \ldots \ldots \cdots$ & 9.084 & 8.985 & 8.80 & 8.45 & 8.939 & 9.323 & 8.53 & $8 \cdot 60$ & 8.65 & 8.56 \\
\hline $\mathrm{H}_{\mathrm{c}}(\mathrm{cm})^{1} \ldots \ldots \ldots \ldots \ldots$ & 7.67 & 8.24 & 8.87 & 8.90 & 8.01 & 6.72 & 8.78 & 8.80 & 8.86 & 8.31 \\
\hline$t_{50}(\min ) \ldots \ldots \ldots \ldots \cdots$ & 180 & 350 & 230 & 170 & 150 & 85 & 105 & 220 & 220 & 96 \\
\hline$t_{100}(\min ) \cdots \cdots \cdots \cdots \cdots$ & 980 & 1800 & 1000 & 850 & 690 & 400 & 470 & 1000 & 1020 & 440 \\
\hline$\sigma_{3 \mathrm{c}}\left(\mathrm{kg} / \mathrm{cm}^{2}\right) \ldots \ldots \ldots \ldots$ & 3.488 & 3.436 & 3.421 & 3.439 & 3.449 & 3.446 & 3.455 & 3.451 & 3.420 & 3.433 \\
\hline$w / c($ after test $)(\%) \ldots \ldots$ & 21.24 & 20.08 & 19.21 & 22.81 & 22.76 & 21.04 & 19.20 & 24.80 & 23.83 & 22.58 \\
\hline B-value ${ }^{2} \ldots \ldots \ldots \ldots \ldots$ & 1.42 & nd & 1.33 & 1.37 & $1 \cdot 58$ & 1.10 & 1.18 & 1.11 & 1.26 & 1.15 \\
\hline$c_{v} \cdot 10^{5}\left(\mathrm{~cm}^{2} / \mathrm{sec}\right) \ldots \cdots \cdots$ & 1.051 & 0.540 & 0.822 & 1.113 & 1.261 & 2.225 & 1.802 & 0.860 & 0.860 & 1.970 \\
\hline \multicolumn{11}{|l|}{ Shearing } \\
\hline Deformation rate $(\mathrm{cm} / \mathrm{min})$ & 0.0004 & 0.0006 & 0.0006 & 0.0006 & 0.0006 & 0.0006 & 0.0006 & 0.0006 & 0.0006 & 0.0006 \\
\hline $\mathrm{U}_{\max } / \sigma_{3 c^{3}}{ }^{3} \ldots \ldots \ldots \ldots$ & 0.578 & 0.609 & 0.514 & 0.590 & 0.559 & 0.583 & 0.563 & 0.632 & 0.577 & 0.521 \\
\hline$\left.\left(\sigma_{1}^{\prime} / \sigma^{\prime}\right)\right)_{\max }{ }^{3} \ldots \ldots \ldots \ldots$ & 2.867 & 2.778 & 3.088 & 2.971 & 2.585 & 2.853 & 3.306 & 2.537 & 2.790 & 2.670 \\
\hline$\sigma^{\prime} 3 f\left(k g / \mathrm{cm}^{2}\right)^{3} \ldots \ldots \ldots$ & 1.938 & 2.269 & 1.746 & 1.558 & 1.829 & 2.078 & 1.872 & 1.993 & 1.814 & 2.423 \\
\hline$U_{f}\left(\mathrm{~kg} / \mathrm{cm}^{2}\right)^{3} \ldots \ldots \ldots \ldots$ & 1.551 & 1.167 & 1.675 & 1.880 & 1.621 & 1.368 & 1.583 & 1.458 & 1.606 & 1.011 \\
\hline$\epsilon_{1 f}(\%)^{3} \ldots \ldots \ldots \ldots \ldots$ & 12.344 & 13.804 & 9.510 & 11.039 & 17.066 & 9.024 & 9.974 & 15.730 & 11.885 & 15.896 \\
\hline$\phi^{\prime}(\text { degree })^{3} \ldots \ldots \ldots \ldots$ & 28.9 & 28.1 & 30.7 & 29.8 & 26.2 & 28.7 & 32.4 & 25.8 & 28.2 & 27.1 \\
\hline$\left(\sigma_{1}-\sigma_{3}\right)_{\max }\left(\mathrm{kg} / \mathrm{cm}^{2}\right)^{4} \ldots$ & 4.296 & 5.295 & 4.777 & 3.805 & 3.361 & 5.198 & 5.457 & 3.639 & 4.066 & 4.455 \\
\hline$\sigma^{\prime}{ }_{3 f}\left(\mathrm{~kg} / \mathrm{cm}^{2}\right)^{4} \ldots \ldots \ldots \ldots$ & 2.478 & 3.248 & 2.523 & 2.086 & 2.248 & 3.327 & 2.570 & 2.557 & 2.701 & 2.779 \\
\hline $\mathrm{U}_{\mathrm{f}}\left(\mathrm{kg} / \mathrm{cm}^{2}\right)^{4} \ldots \ldots \ldots \cdots$ & 1.010 & 0.188 & 0.898 & 1.352 & 1.202 & 0.119 & 0.886 & 0.893 & 0.719 & 0.654 \\
\hline$\epsilon_{1 f}(\%)^{4} \ldots \ldots \ldots \ldots \ldots$ & 22.567 & 32.529 & 26.345 & 24.932 & 26.698 & 27.401 & 24.128 & 29.741 & 33.133 & 24.827 \\
\hline$\phi(\text { degree })^{4} \ldots \ldots \ldots \ldots$ & 27.7 & $26 \cdot 7$ & 29.1 & 28.5 & 25.3 & 26.0 & 31.0 & 24.6 & $25 \cdot 4$ & 26.4 \\
\hline$\epsilon_{1 \max }(\%) \quad \ldots \ldots \ldots \ldots \ldots$ & 22.567 & 32.529 & 28.789 & 30.502 & 26.698 & 35.951 & 24.128 & 29.741 & 34.579 & 33.176 \\
\hline
\end{tabular}

1 Some of the soft, remolded specimens elongated silghtly upon placement of the membranes. This is considered in calculation of $A_{c}$ and $H_{c}\left(V_{0}=\right.$ constant).

$$
\begin{aligned}
& { }^{2} \text { B-values are determined after } 5 \text { minutes or, in a few cases, after } 10 \text { minutes. } \\
& { }^{3} \text { At }\left(\sigma_{1}^{\prime} / \sigma^{\prime}{ }_{3}\right)_{\text {max }} \text {. } \\
& { }^{4} \text { At }\left(\sigma_{1}-\sigma_{3}\right)_{\text {max }} \text {. }
\end{aligned}
$$

maximum shearing stress, $\mathrm{q}$, that correspond to the peak points of the stress-strain curves for each test. The line drawn through these points, commonly termed the $K_{f}$ line, has a slope angle, $\alpha$, of $25.54^{\circ}$. The effective friction angle $\phi^{\prime}$ is related to $\alpha$ (Lambe and Whitman, 1979) by

$$
\sin \phi^{\prime}=\tan \alpha .
$$

From figure 12, $\alpha=25.540$; therefore, the mean effective friction angle for the Bootlegger Cove Formation samples tested is approximately $28.5^{\circ}$.

The undrained shear strengths from the ICU tests are also shown on figure 11. Partly due to the substantial volumetric compression of the remolded specimens during the consolidation phase, their undrained shear strengths are much higher than those obtained from the ICU tests that were performed on the intact specimens during the resonant column testing program (see Updike and others, 1982). 


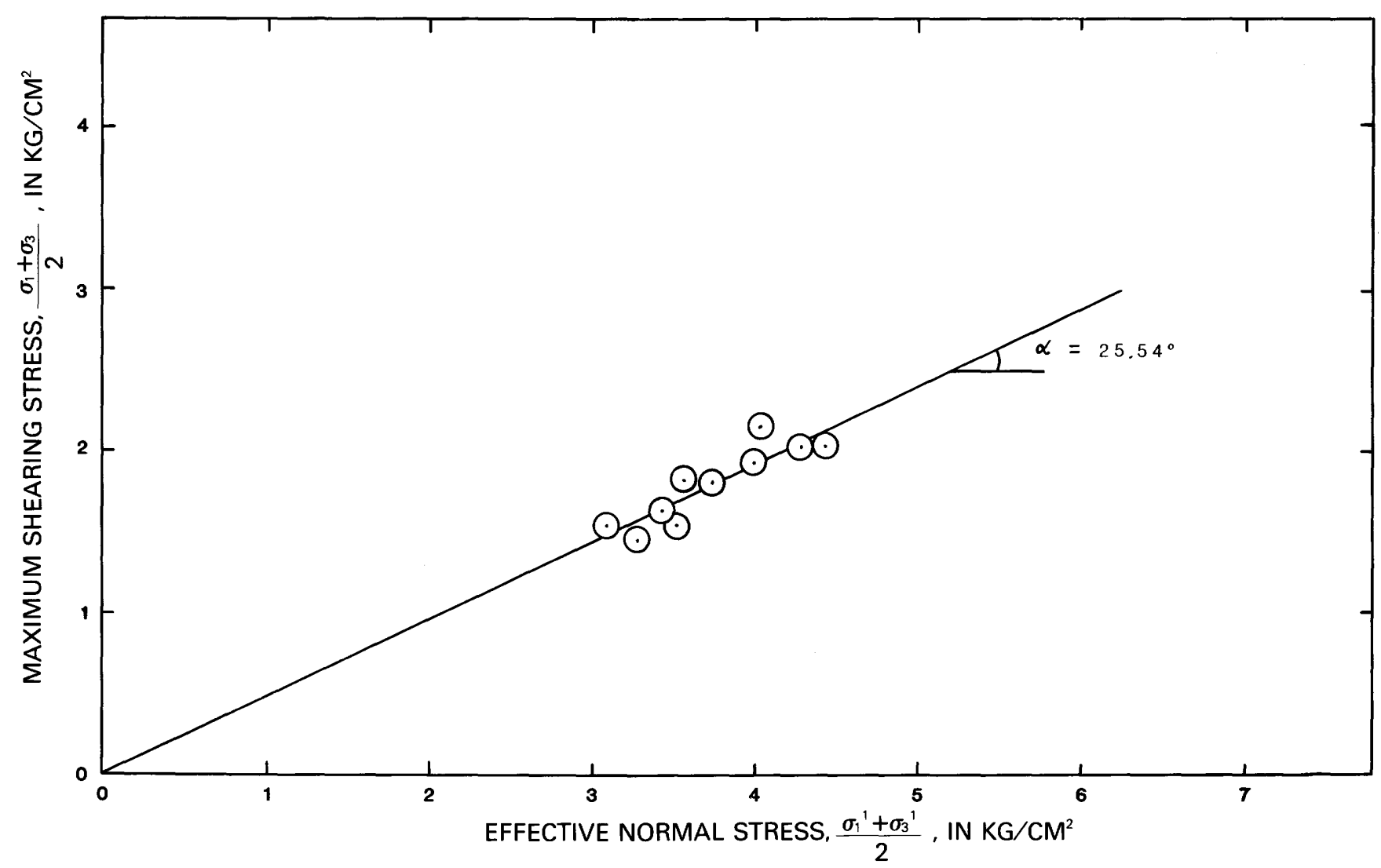

Figure 12. The $p-q$ diagram of effective normal stress versus maximum shearing stress as determined by ten iostropically consolidated-undrained tests on the Bootlegger Cove Formation. The angle of inclination, $\alpha$, of the "best-fit line", $K_{f}$, through the points is $25.54^{\circ}$.

\section{Cyclic Loading Tests}

The initial conditions and the stress conditions for the cyclic loading tests on intact specimens are summarized in table 4, and those for the cyclic loading tests on remolded specimens are summarized in table 5. These tables contain the water contents, specimen geometries, initial wet densities, vertical and volumetric strains due to consolidation, consolidation times, coefficients of consolidation, actual $K_{c}$-values, and stresses applied during static and cyclic phases of the tests. These tables also show that the $B$-values for the triaxial specimens decrease with increasing consolidation stress ratios. This behavior does correspond to fully saturated specimens as discussed in detail by Lade and Kirkgard (1984). Detailed test results including sketches of intact specimens, consolidation curves, and $\mathrm{X}-\mathrm{Y}$ recordings of cyclic stress-strain relationships were also recorded. Figures 13-15 show representative deformed shapes of three samples, under both intact and remolded initial conditions.

\section{Strength Relations for Intact Specimens}

In order to interpret the strength results of the cyclic loading tests that were performed on specimens with consolidation ratios of $K_{c}=1.0$, the axial peak-topeak strains are plotted versus number of cycles on a semilog diagram for different cyclic stress ratios (fig. 16). The cyclic stress ratio is defined as $\sigma_{d \max } / 2 \mathrm{~S}_{u}$, in which $S_{u}$ is the static undrained strength and $\sigma_{d \max }=\sigma_{d c}+\sigma_{d p}$, in which $\sigma_{d c}$ is the stress difference during consolidation and $\sigma_{d p}$ is the cyclic (pulsating) stress difference. Based on the diagram in figure 16, another diagram is constructed in which the cyclic stress ratio is plotted versus the number of cycles that are required to cause various amounts of axial peak-to-peak strains (figs. 17, 18).

The values of undrained shear strength, $S_{u}$, that were determined from the UU tests on intact specimens were used for calculation of the cyclic stress ratio shown in figure 17. ICU tests on intact specimens were not performed. However, based on the shear strength diagram in figure 11, approximate values of $S_{u}$ from tests on intact specimens were estimated and used for the cyclic stress ratios employed in figure 18. Diagrams of this type are plotted for all cyclic tests on intact specimens. These diagrams are produced to make a direct comparison of results from cyclic loading tests on intact and remolded 

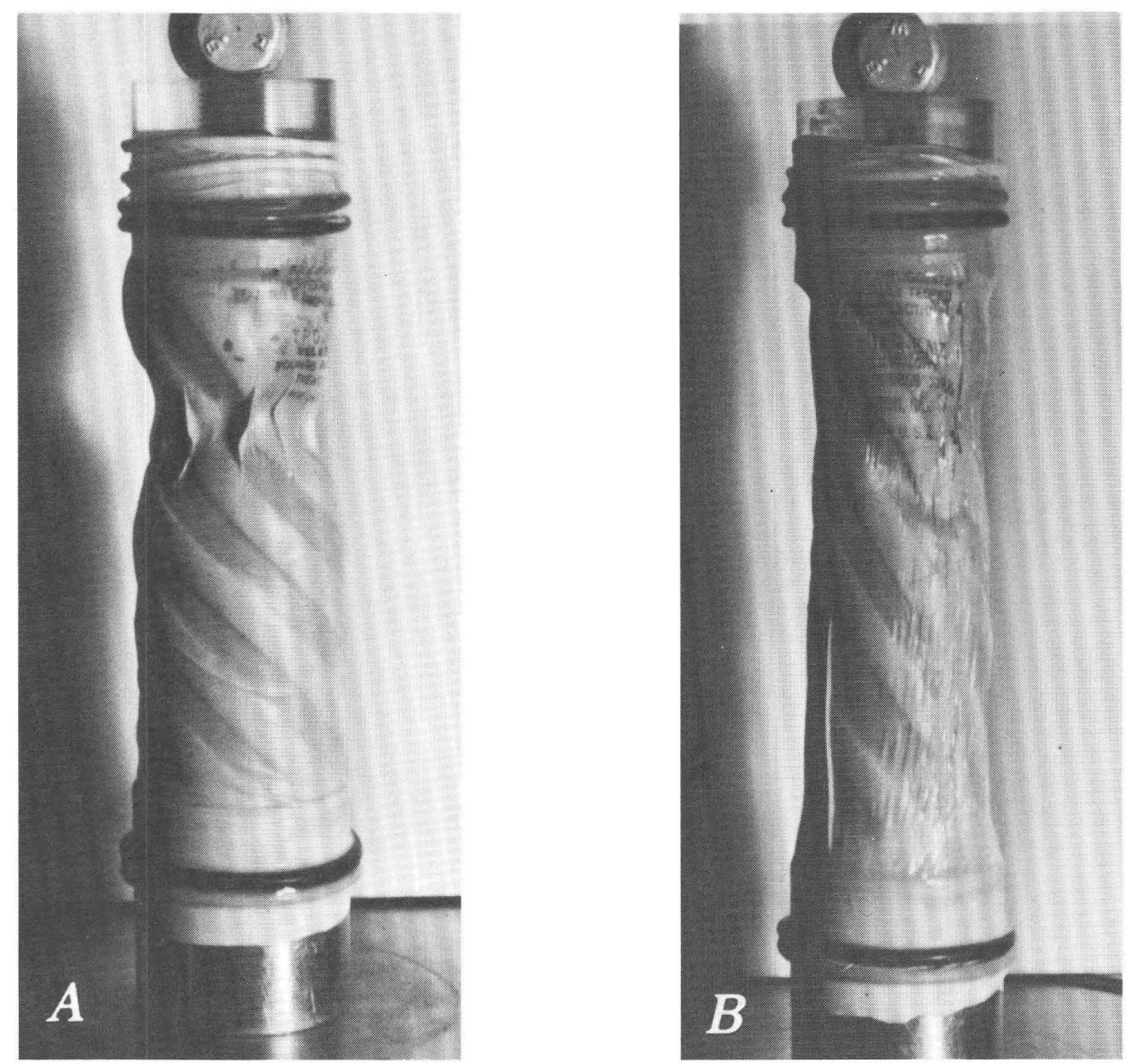

Figure 13. Specimen $\mathrm{CT}-5$ (facies F.IV of the Bootlegger Cove Formation) after consolidation at stress ratio, $K_{c}=1.0$, and after failure by cyclic loading. Note the sample failed in extension. A, Intact specimen; B, Remolded specimen. Specimen about $15 \mathrm{~cm}$ long.

specimens. For this comparison a common basis, such as results of ICU tests, is required.

There are, however, several reasons why the estimated values of undrained shear strength from ICU tests on intact specimens may be incorrect. The estimated strengths are based on results from tests on remolded specimens or from tests on intact specimens which were first exposed to resonant column testing (see fig. 11). Because remolded or disturbed specimens may behave differently from intact specimens of sensitive soils, it is preferable to employ truly intact specimens for determination of undrained shear strengths. Therefore, to provide a common basis for comparisons of the type described above, ICU tests on intact specimens should be performed in connection with future studies of the cyclic behavior of the Bootlegger Cove Formation. Unfortunately, this work was beyond the scope of funding and sample availability in the present study.

For the cyclic loading tests with initial consolidation stress ratios of $K_{c}=1.5$ and 2.0, the maximum axial strains are plotted versus number of cycles on semilog diagrams for different cyclic stress ratios for intact specimens (figs. 19, 20). Based on these diagrams, other diagrams are constructed on which the cyclic stress ratio is plotted versus the number of cycles that are required to cause various amounts of maximum axial strains (figs. 21-24).

The permanent axial strains observed in the cyclic loading tests on specimens with $K_{c}=1.0$ are negative and relatively small, and this corresponds to failure in extension as observed in these tests (see fig. 13). The permanent axial strains obtained in tests with $K_{c}=1.5$ and 2.0 are positive and increase to large values, and failure in these tests occurs in compression (figs. 14, 15). The axial peak-to-peak strains in these tests are comparatively small $\left(\epsilon_{\max }=3\right.$ percent for $K_{c}=1.5$, and $\epsilon_{\max }=0.4$ percent for $K_{c}=2.0$ ). Thus, a common basis for a direct comparison between tests with $K_{c}=1.0$ and tests with $K_{c}=1.5$ and 2.0 is absent. Nevertheless, to get an idea of the relative strengths obtained from the tests with different $K_{c}$-values, cyclic stress ratios are plotted versus number of cycles on a semilog diagram for axial 

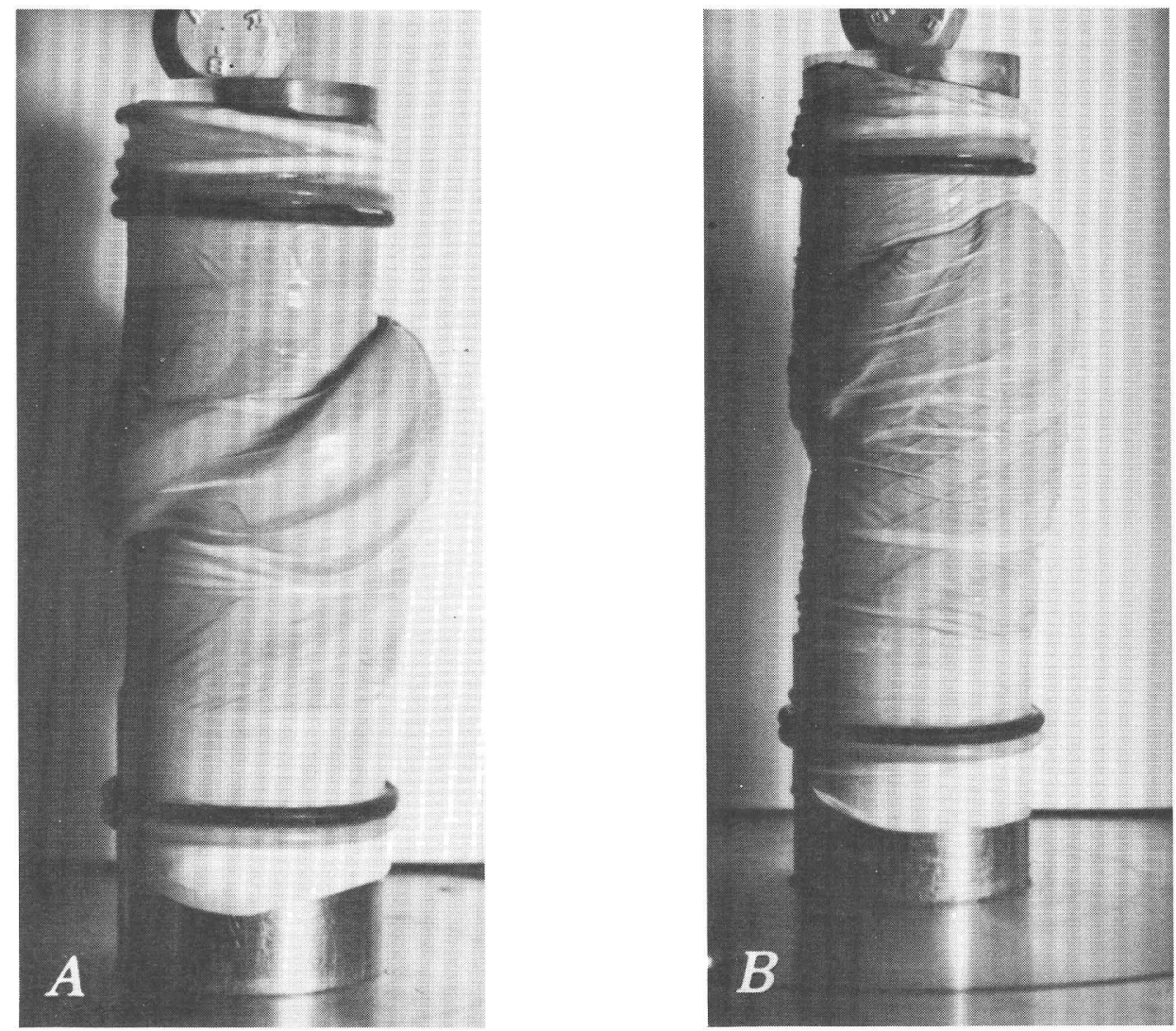

Figure 14. Specimen CT-3 (facies F.III of the Bootlegger Cove Formation) after consolidation at stress ratio, $K_{c}=1.5$, and after failure by cyclic loading. Note the sample failed in compression. A, Intact specimen; B, Remolded specimen. Specimen about $15 \mathrm{~cm}$ long.

peak-to-peak strains of 5.0 for $K_{c}=1.0$ and for maximum axial strains of 10 percent for $K_{c}=1.5$ and 2.0 (fig. 25). This figure indicates that the cyclic stress ratio to cause 10 percent axial strain (peak-to-peak or maximum) increases with increasing consolidation stress ratio for a given number of cycles.

\section{Discussion of Cyclic Stress Ratio}

The cyclic stress ratios discussed above involve the undrained shear strengths that were determined from the UU tests on intact specimens. In an attempt to obtain a direct comparison between tests on intact soil and tests on remolded soil, the cyclic load applied in the tests on intact specimens was also used for the remolded specimens. Thus, it was not necessary to rely on a static undrained shear strength for the remolded soil to estimate the cyclic stress from a cyclic stress ratio. However, due to the larger amounts of volume change for the remolded specimens, the cross-sectional areas of these specimens were smaller and the cyclic stress therefore was higher for the remolded specimens than for the intact specimens.
Depending upon the objective, it is possible to use two different static, undrained shear strengths for calculation of the cyclic stress ratio for remolded soil: (1) that obtained from UU tests, and (2) that obtained from ICU tests. The first value is very easy to obtain, but it is a small number with substantial scatter, which results in high cyclic load ratios with significant scatter. Furthermore, this value does not reflect the consolidation that follows disturbance due to an earthquake. To obtain the second value requires relatively advanced equipment and a considerable amount of time. However, the second value is much higher and should be more consistent than the first value. Its use will result in lower cyclic stress ratios, with less scatter. Both values have been employed in separate evaluations of the cyclic loading tests on remolded soil.

\section{Strength Relations for Remolded Specimens}

The procedure for evaluation of the cyclic loading tests on remolded specimens is similar to that described above for the intact specimens. Figures 26-28 show the 

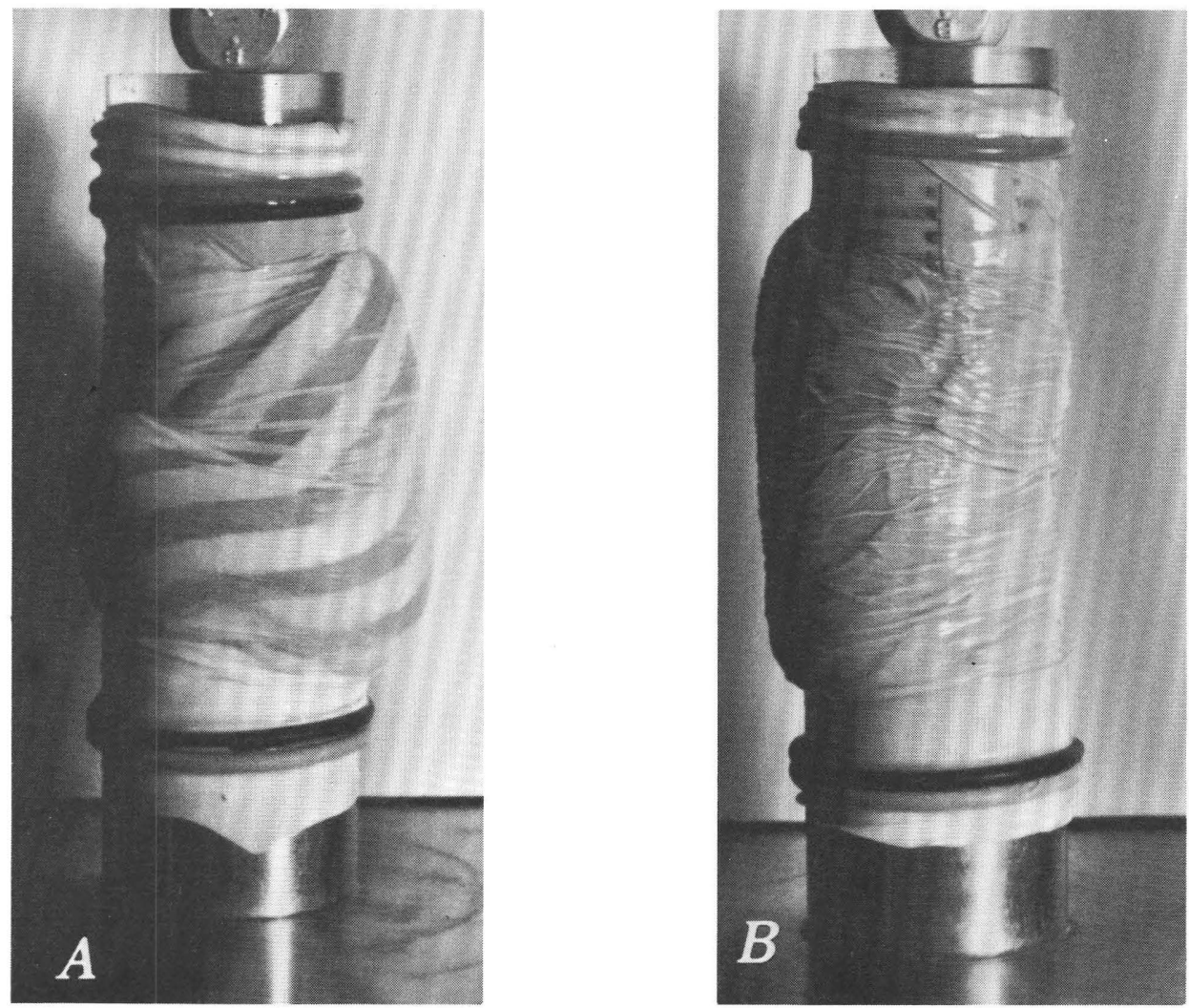

Figure 15. Specimen CT-4 (facies F.IV of the Bootlegger Cove Formation) after consolidation at stress ratio, $K_{c}=2.0$, and after failure by cyclic loading. Note the sample failed by compression. A, Intact specimen; B, Remolded specimen. Specimen about $15 \mathrm{~cm}$ long.

axial strains (peak-to-peak for $K_{c}=1.0$ and maximum for $K_{c}=1.5$ and 2.0) plotted versus number of cycles for tests with various cyclic stress ratios. Corresponding to the two different types of undrained shear strengths, two values of cyclic stress ratios are indicated on these figures. Figures 29-31 show the cyclic stress ratios in terms of the undrained shear strength from the UU tests plotted versus the number of cycles that are required to cause various amounts of axial strain. In figures $32-34$, the cyclic stress ratios in terms of the undrained shear strength from the ICU tests are plotted versus the number of cycles that are required to cause various amounts of axial strain. The application of the strengths from the UU tests results in much higher stress ratios than those obtained using the strengths from the ICU tests.

\section{Comparison of Strength Relations for Intact and Remolded Specimens}

Using the undrained shear steength from the UU tests, a comparison of all tests on remolded soils is shown in figure 35 . Despite the problems with such a comparison, it can be seen that the cyclic stress ratio that is required to cause 10 percent axial strains (peak-to-peak or maximum) increases with increasing consolidation stress ratio for a given number of cycles. The test results for the intact specimens are also shown on figure 35, and the cyclic stress ratios that are required to cause 10 percent axial strain in these specimens are much smaller than those required for the remolded specimens. It should be recalled, however, that the unconfined shear strength used for the remolded soil does not reflect the effect of consolidation after remolding. These strengths are relatively small and result in high cyclic stress ratios for the remolded specimens.

Using the undrained shear strength from the ICU tests, a comparison of all tests on remolded soil is shown in figure 36 . The cyclic stress ratios are substantially lower than those shown in figure 35 , but the conclusions regarding the cyclic strength are similar to those presented above. In comparing the cyclic stress ratios for the remolded specimens with those for intact specimens (fig. 37), it appears that the intact specimens are stronger than the remolded specimens. However, this is misleading. The undrained shear strengths used in the cyclic stress ratios are not directly comparable because the intact specimens are exposed to lower effective confining pressures in the 
Table 4. Summary of initial and stress conditions for cyclic loading tests on Bootlegger Cove Formation intact specimens [See "GLOSSARY OF SYMBOLS USED" for definitions of symbols]

\begin{tabular}{|c|c|c|c|c|c|c|c|c|c|c|}
\hline Sample & $\mathrm{CT}-1$ & $\mathrm{CT}-2$ & $\mathrm{CT}-3$ & $\mathrm{CT}-4$ & $\mathrm{CT}-5$ & $\mathrm{CT}-6$ & $\mathrm{CT}-7$ & $\mathrm{CT}-8$ & $\mathrm{CT}-9$ & $\mathrm{RC}-6$ \\
\hline \multicolumn{11}{|l|}{ Before consolidation } \\
\hline w/c (trimmings) $(\%)$. & 28.06 & 30.08 & 38.47 & 32.68 & 30.66 & 28.65 & 23.13 & 34.40 & 31.69 & 29.76 \\
\hline$A_{o}\left(c^{2}\right) \ldots \ldots \ldots$ & 9.931 & 9.931 & 9.931 & 9.931 & 9.931 & 9.931 & 9.931 & 9.931 & 9.931 & 9.931 \\
\hline $\mathrm{H}_{\mathrm{o}}(\mathrm{cm}) \ldots \ldots \ldots \ldots$ & 7.518 & 8.839 & 8.433 & 8.585 & 8.484 & 8.407 & 8.814 & 8.814 & 7.087 & 8.839 \\
\hline$v_{o}\left(\mathrm{~cm}^{3}\right) \ldots \ldots \ldots$ & 74.67 & 87.78 & 83.75 & 85.26 & 84.25 & 83.49 & 87.53 & 87.53 & 70.38 & 87.78 \\
\hline$\gamma_{\text {wet }}\left(\mathrm{g} / \mathrm{cm}^{3}\right) \ldots \ldots \ldots$ & 1.981 & 1.983 & 1.865 & 1.944 & 1.957 & 2.000 & 2.079 & 1.935 & 1.957 & 1.980 \\
\hline \multicolumn{11}{|l|}{ After consolidation } \\
\hline$\Delta v_{\text {consol }}\left(\mathrm{cm}^{3}\right) \ldots \ldots$ & 5.587 & 6.315 & 5.686 & 7.691 & 4.599 & 4.230 & 2.674 & 5.188 & 4.100 & 5.467 \\
\hline$\Delta \delta_{\text {consol }}(\mathrm{cm}) \ldots \ldots$ & 0.219 & 0.401 & 0.562 & 1.189 & 0.249 & 0.264 & 0.280 & 0.353 & 0.456 & 0.221 \\
\hline$\epsilon_{\operatorname{vconsol}}(\%) / \ldots \cdots$ & $\begin{array}{l}7.48 / \\
2.91\end{array}$ & $\begin{array}{l}7.19 / \\
4.54\end{array}$ & $\begin{array}{l}6.79 / \\
6.67\end{array}$ & $\begin{array}{l}9.02 / \\
13.84\end{array}$ & $\begin{array}{l}5.46 / \\
2.94\end{array}$ & $\begin{array}{l}5.07 / \\
3.14\end{array}$ & $\begin{array}{l}3.05 / \\
3.18\end{array}$ & $\begin{array}{l}5.93 / \\
4.01\end{array}$ & $\begin{array}{l}5.83 / \\
6.43\end{array}$ & $\begin{array}{l}6.23 / \\
2.50\end{array}$ \\
\hline$A_{c}\left(\mathrm{~cm}^{2}\right) \ldots \ldots \ldots$ & 9.464 & 9.66 & 9.92 & 10.49 & 9.67 & 9.73 & 9.94 & 9.73 & 10.00 & 9.55 \\
\hline $\mathrm{H}_{\mathrm{c}}(\mathrm{cm}) \ldots \ldots \ldots \cdots$ & $7 \cdot 30$ & 8.39 & 7.87 & 7.40 & 8.23 & 8.15 & 8.53 & 8.46 & 6.63 & 8.62 \\
\hline $\mathrm{t}_{50}(\min ) \cdots \cdots \cdots \cdot$ & 14 & $150 \quad 130$ & 56 & 70 & 86 & 32 & 100 & 70 & 92 & \\
\hline $\mathrm{t}_{100}(\mathrm{~min}) \cdots \cdots \cdots$ & 94 & 760700 & 270 & 440 & 420 & 150 & 740 & 500 & 430 & \\
\hline$\sigma_{3 \mathrm{c}}\left(\mathrm{kg} / \mathrm{cm}^{2}\right) \ldots \ldots$ & 3.515 & 3.515 & 3.515 & 3.515 & 3.515 & 3.515 & 3.515 & 3.515 & 3.515 & 3.515 \\
\hline$\sigma_{\mathrm{dc}}\left(\mathrm{kg} / \mathrm{cm}^{2}\right)^{1} \ldots \ldots$ & 0.0 & 1.807 & 1.759 & 3.328 & 0.0 & 0.0 & 3.512 & 1.794 & 3.491 & 0.0 \\
\hline $\mathrm{K}_{\mathrm{c}}=\sigma_{1 \mathrm{c}} / \sigma_{3 \mathrm{c}} \cdots \cdots$ & 1.0 & 1.514 & 1.501 & 1.947 & 1.0 & 1.0 & 1.999 & 1.510 & 1.993 & 1.0 \\
\hline$c_{v} \cdot 10^{5}\left(\mathrm{~cm}^{2} / \mathrm{sec}\right) \ldots$ & 11.823 & 1.261 & 1.455 & 3.378 & 2.702 & 2.200 & 5.911 & 1.892 & 0.370 & 2.056 \\
\hline B-value ${ }^{2} \ldots \ldots \ldots$ & 1.012 & $\begin{array}{l}0.938 / \\
1.012\end{array}$ & 0.890 & 0.878 & $1.028 /$ & 0.967 & 0.769 & $\begin{array}{l}0.983 / \\
0.894 / \\
0.882\end{array}$ & $\begin{array}{l}0.935 / \\
0.884 /\end{array}$ & $\begin{array}{l}0.929 / \\
1.000\end{array}$ \\
\hline $\mathrm{K}_{\mathrm{c}} /$ Delay (min) $\ldots$. & $1.0 / 10$ & $\begin{array}{l}1.5 / 5 \\
1.5 / 10\end{array}$ & $1.5 / 5$ & $2.0 / 5$ & $1.0 / 5$ & $1.0 / 5$ & $2.0 / 5$ & $\begin{array}{l}1.0 / 5 \\
1.5 / 5 \\
2.0 / 5\end{array}$ & $\begin{array}{l}1.0 / 5 \\
1.5 / 5\end{array}$ & $\begin{array}{l}1.0 / 5 \\
1.0 / 10\end{array}$ \\
\hline \multicolumn{11}{|l|}{ Cyclic Loading } \\
\hline Frequency $(\mathrm{Hz}) \ldots \ldots$ & 1 & 1 & 1 & 1 & 1 & 1 & 1 & 1 & 1 & \\
\hline $\pm P_{d p}(k g) \ldots \ldots \ldots \ldots \pm$ & \pm 14.9 & \pm 20.8 & \pm 16.0 & \pm 20.7 & \pm 19.6 & \pm 35.9 & \pm 22.7 & \pm 17.2 & \pm 16.5 & $\pm 17 \cdot 3$ \\
\hline $\begin{array}{l} \pm \sigma_{d_{p}}= \pm P_{d_{p}} / A_{c} \cdots \\
\quad\left(k g / \mathrm{cm}^{2}\right)\end{array}$ & \pm 1.58 & \pm 2.15 & \pm 1.61 & \pm 1.97 & \pm 2.03 & \pm 3.69 & \pm 2.28 & \pm 1.77 & \pm 1.65 & \pm 1.81 \\
\hline $\begin{array}{l}\sigma_{\mathrm{dmax}}=\sigma_{\mathrm{dc}}+\sigma_{\mathrm{dp}} \cdots \\
\quad\left(\mathrm{kg} / \mathrm{cm}^{2}\right)\end{array}$ & 1.58 & 3.96 & 3.37 & 5.30 & 2.03 & 3.69 & 5.79 & 3.56 & 5.14 & 1.81 \\
\hline $\mathrm{s}_{\mathrm{u}}(\mathrm{static})\left(\mathrm{kg} / \mathrm{cm}^{2}\right)$ & 0.507 & 0.624 & 0.672 & 0.531 & 0.603 & 1.126 & 0.798 & 0.620 & 0.829 & 0.560 \\
\hline$s_{p} / s_{u}\left(s_{p}=1 / 2 \sigma_{d p}\right)$ & 1.56 & 1.72 & 1.20 & 1.86 & 1.68 & 1.164 & 1.43 & 1.43 & 1.00 & 1.62 \\
\hline $\mathrm{N}_{\max }\left[\mathrm{N}_{\mathrm{f}}\right] \ldots \ldots \ldots \ldots[=$ & $=75]$ & {$[=14]$} & {$[=26]$} & {$[=47]$} & {$[=15]$} & {$[=2]$} & {$[=96]$} & {$[=31]$} & {$[=75]$} & {$[=32]$} \\
\hline$\sigma_{\mathrm{dmax}} / 2 \mathrm{~s}_{\mathrm{u}} \cdots \ldots \ldots \ldots$ & 1.56 & 3.17 & 2.51 & 4.99 & 1.68 & 1.64 & 3.63 & 2.87 & 3.10 & 1.62 \\
\hline
\end{tabular}

${ }_{1}$ B-values are determined after 5 minutes or, in a few cases, after 10 minutes. 
Table 5. Summary of initial and stress conditions for cyclic loading tests on Bootlegger Cove Formation remolded specimens [nd, not determined. See "GLOSSARY OF SYMBOLS USED” for definitions of symbols]

\begin{tabular}{|c|c|c|c|c|c|c|c|c|c|c|c|c|}
\hline \multirow{2}{*}{ Sample } & \multirow[t]{2}{*}{$\mathrm{CT}-1$} & \multirow[t]{2}{*}{$\mathrm{CT}-2$} & \multirow[t]{2}{*}{ C T -3} & \multicolumn{2}{|c|}{ CT-4 } & \multirow[t]{2}{*}{$\mathrm{CT}-5$} & \multirow[t]{2}{*}{$\mathrm{CT}-6$} & \multicolumn{2}{|c|}{ C T -7} & \multirow[t]{2}{*}{$\mathrm{CT}-8$} & \multirow[t]{2}{*}{$\mathrm{CT}-9$} & \multirow[t]{2}{*}{$\mathrm{RC}-6$} \\
\hline & & & & $1 \mathrm{st}$ run & $2 \mathrm{a}$ run & & & $1 \mathrm{~s} \mathrm{c}$ & 20 run & & & \\
\hline \multicolumn{13}{|l|}{ Before consolidation } \\
\hline w/c (trimmings) $(\%)$ & 27.54 & 27.56 & 36.22 & 30.82 & nd & 29.46 & 27.30 & 22.65 & nd & 31.99 & 30.40 & 28.80 \\
\hline$A_{o}\left(\mathrm{~cm}^{2}\right)^{1} \ldots \ldots \ldots$ & 9.931 & 9.931 & 9.931 & 9.931 & nd & 9.79 & 9.781 & 9.931 & nd & 9.931 & 9.931 & 9.82 \\
\hline $\mathrm{H}_{\mathrm{o}}(\mathrm{cm})^{1} \ldots \ldots \ldots$ & 7.569 & 8.814 & 8.814 & 8.712 & nd & 8.738 & 8.832 & 8.712 & nd & 8.814 & 8.788 & 8.941 \\
\hline$v_{o}\left(\mathrm{~cm}^{3}\right) \ldots \ldots \ldots$ & 75.17 & 87.53 & 87.53 & 86.52 & nd & 85.51 & 81.98 & 87.52 & nd & 87.53 & 87.28 & 87.78 \\
\hline$\gamma_{\text {wet }}\left(\mathrm{g} / \mathrm{cm}^{3}\right) \ldots \ldots$ & 2.030 & 2.034 & 1.940 & 2.012 & nd & 1.996 & 2.025 & 2.178 & nd & 1.958 & 2.030 & 2.019 \\
\hline \multicolumn{13}{|l|}{ After consolidation } \\
\hline$\Delta v_{\text {consol }}\left(\mathrm{cm}^{3}\right) \ldots \ldots$ & 7.871 & 9.617 & 11.911 & 10.744 & 11.133 & 8.739 & 7.721 & 8.430 & 8.809 & 11.542 & 10.495 & 8.500 \\
\hline$\Delta \delta_{\text {consol }}(\mathrm{cm}) \ldots \ldots$ & 0.030 & 0.226 & 0.460 & 0.522 & $\mathrm{nd}$ & 0.151 & 0.093 & 0.316 & nd & 1.439 & 0.691 & 0.160 \\
\hline 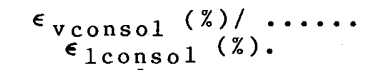 & $\begin{array}{c}10.471 \\
0.40\end{array}$ & $\begin{array}{c}10.99 / \\
2.57\end{array}$ & $\begin{array}{c}13.611 \\
5.22\end{array}$ & $\begin{array}{l}12.421 \\
5.99\end{array}$ & nd & $\begin{array}{l}10.221 \\
1.73\end{array}$ & $\begin{array}{l}9.421 \\
1.11\end{array}$ & $\begin{array}{l}9.74 / \\
3.63\end{array}$ & nd & $\begin{array}{c}13.17 / \\
4.98\end{array}$ & $\begin{array}{l}12.021 \\
7.86\end{array}$ & $\begin{array}{l}9.68 / \\
.79\end{array}$ \\
\hline$A_{c}\left(c^{2}\right) \ldots \ldots \cdots$ & 8.93 & 9.07 & 9.05 & 8.42 & 10.11 & 8.94 & 8.96 & 9.30 & 10.49 & 9.07 & 9.48 & 9.03 \\
\hline $\mathrm{H}_{\mathrm{c}}(\mathrm{cm}) \ldots \ldots \ldots \ldots$ & 7.54 & 8.55 & 8.35 & 8.19 & 7.46 & 8.59 & 8.29 & 8.39 & 7.41 & 8.37 & 8.10 & 8.78 \\
\hline $\mathrm{t}_{50}(\min ) \ldots \ldots \ldots$ & 70 & 580 & 560 & 230 & nd & 180 & 180 & 100 & nd & 400 & 450 & 170 \\
\hline $\mathrm{t}_{100}(\mathrm{~min}) \ldots \ldots \ldots$ & 330 & 3200 & 3200 & 1100 & nd & 900 & 940 & 500 & nd & 1700 & 2300 & 870 \\
\hline$\sigma_{3 \mathrm{c}}\left(\mathrm{kg} / \mathrm{cm}^{2}\right) \ldots \ldots$ & 3.515 & 3.515 & 3.515 & 3.515 & 3.515 & 3.515 & 3.515 & 3.515 & 3.515 & 3.515 & 3.515 & 3.515 \\
\hline$\sigma_{\mathrm{dc}}\left(\mathrm{kg} / \mathrm{cm}^{2}\right) \ldots \ldots$ & 0.0 & 1.924 & 3.929 & 4.146 & 3.543 & 0.0 & 0.0 & 3.753 & 3.328 & 1.924 & 3.682 & 0.0 \\
\hline $\mathrm{K}_{\mathrm{c}}=\sigma_{1 \mathrm{c}} / \sigma_{3 \mathrm{c}} \cdots \cdots$ & 1.0 & 1.547 & 1.549 & 2.179 & 1.982 & 1.0 & 1.0 & 2.068 & 1.947 & 1.547 & 2.048 & 1.0 \\
\hline$w / c$ (after test) $(\%)$ & 20.25 & 19.25 & 25.36 & nd & 20.63 & 21.93 & 20.99 & nd & 15.98 & 22.34 & 21.81 & 20.50 \\
\hline B-value $\ldots \ldots \ldots$ & 0.867 & 1.079 & $\begin{array}{l}0.944 / \\
0.930\end{array}$ & 0.904 & nd & 1.281 & 1.077 & 0.930 & nd & 0.925 & 0.863 & 1.022 \\
\hline $\mathrm{K}_{\mathrm{c}} /$ Delay $(\min ) \ldots \ldots$ & $1.0 / 5$ & $1.0 / 5$ & $\begin{array}{l}1.0 / 5 \\
1.5 / 5\end{array}$ & $2.0 / 5$ & nd & $1.0 / 5$ & $1.0 / 5$ & $2.0 / 5$ & nd & $1.5 / .5$ & $2.0 / 5$ & $\therefore 1.0 / 5$ \\
\hline \multicolumn{13}{|l|}{ Cyclic Loading } \\
\hline Frequency $(\mathrm{Hz}) \quad \ldots$ & 1 & 1 & 1 & 1 & 1 & 1 & 1 & 1 & 1 & 1 & 1 & 1 \\
\hline$\neq P_{d p}(k g) \ldots \ldots \ldots$ & \pm 14.4 & \pm 21.3 & \pm 16.0 & \pm 20.7 & \pm 29.9 & $\neq 19.9$ & \pm 35.2 & \pm 23.1 & \pm 38.3 & \pm 17.2 & \pm 16.7 & \pm 17.9 \\
\hline $\begin{array}{l} \pm \sigma_{d p}= \pm P_{d p} / A_{c} \cdots \\
\quad\left(\mathrm{kg} / \mathrm{cm}^{2}\right)\end{array}$ & \pm 1.61 & \pm 2.35 & \pm 1.77 & \pm 2.46 & \pm 2.96 & \pm 2.23 & \pm 3.93 & \pm 2.48 & \pm 3.65 & \pm 1.90 & \pm 1.76 & \pm 1.98 \\
\hline $\begin{array}{l}\sigma_{\mathrm{dmax}}=\sigma_{\mathrm{dc}}+\sigma_{\mathrm{dp}} \cdots \\
\left(\mathrm{kg} / \mathrm{cm}^{2}\right)\end{array}$ & 1.61 & 4.27 & 3.70 & 6.61 & 6.41 & 2.23 & 3.93 & 6.23 & 6.98 & 3.45 & 5.44 & 1.98 \\
\hline $\mathrm{S}_{\mathrm{u}}^{*}(\mathrm{static})\left(\mathrm{kg} / \mathrm{cm}^{2}\right)$ & 0.126 & 0.171 & 0.156 & 0.115 & 5.0 .115 & 0.155 & 0.428 & 0.175 & 0.175 & 0.128 & 0.130 & 0.139 \\
\hline$s_{p} / s_{u}\left(s_{p}=1 / 2 \sigma_{d p}\right)$ & 6.39 & 6.87 & 5.67 & 10.70 & 12.87 & 14.39 & 9.18 & 7.09 & 10.43 & 7.42 & 6.77 & 7.12 \\
\hline $\mathrm{N}_{\mathrm{max}}\left[=\mathrm{N}_{\mathrm{f}}\right] \ldots \ldots \ldots$ & {$[=60]$} & {$\left[\begin{array}{llll}1 & 3 & 3\end{array}\right]$} & 1500 & 1504 & 1506 & {$[=20]$} & {$[=4]$} & 1508 & 50.0 & 1510 & 1508 & {$[=40]$} \\
\hline$\sigma_{\mathrm{dmax}} / 2 \mathrm{~s}_{\mathrm{u}} \ldots \ldots \ldots \ldots$ & 6.39 & 12.49 & 11.86 & 28.74 & 27.87 & 14.39 & 9.18 & 17.80 & 19.94 & 13.48 & 20.92 & 7.12 \\
\hline$c_{v} \cdot 10^{5}\left(\mathrm{~cm}^{2} / \mathrm{sec}\right) \cdots$ & 2.365 & 0.326 & 0.338 & 0.822 & nd & 1.051 & 1.051 & 1.892 & nd & 0.473 & 0.420 & 1.113 \\
\hline
\end{tabular}

l Some remolded specimens elongated slightly upon placement of the membranes. This was considered in calculation of Ac and $\mathrm{H}_{\mathrm{c}}$. 


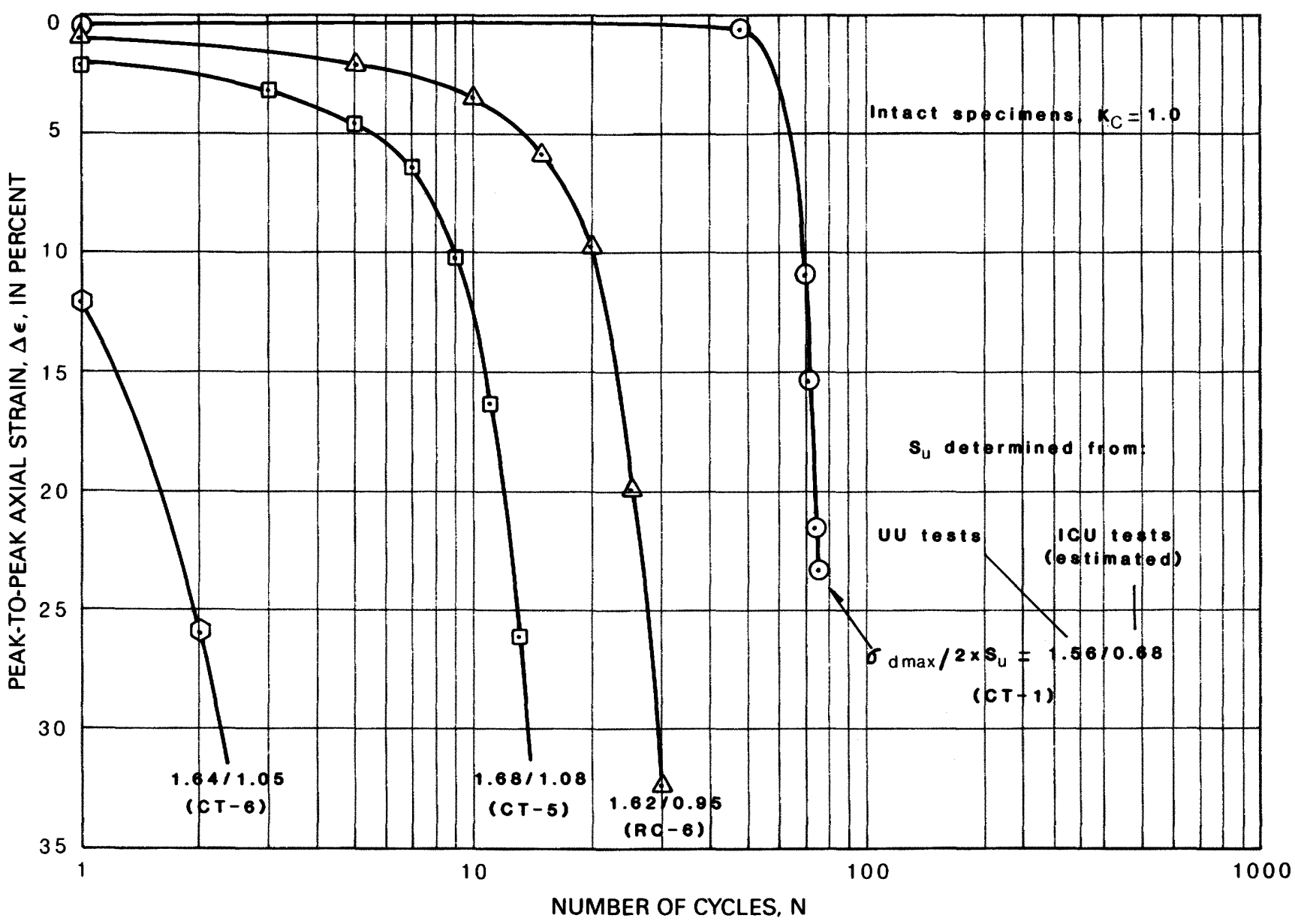

Figure 16. Peak-to-peak axial strain versus number of cycles for intact samples CT-1, CT-5, CT-6, and RC-6, all at initial consolidation ratios of 1.0 .

UU tests, which results in lower shear strengths, than those employed in the ICU tests on remolded specimens.

A comparison of cyclic strengths of intact and remolded specimens on a more equitable basis is shown in figure 38. Values of undrained shear strength from ICU tests are used for both intact (estimated values) and remolded (measured values) specimens. Although the estimated values for intact specimens may be questionable in many respects, figure 38 indicates that the cyclic stress ratios for intact and remolded specimens are comparable in magnitude. However, a final evaluation and conclusion must be postponed until actual ICU tests on intact specimens have been performed in future testing programs.

\section{Shear Moduli}

Comparisons of shear moduli obtained from cyclic loading tests and resonant column tests are shown on figures 39-42. The shear moduli are normalized on the basis of undrained shear strengths as determined in UU tests and ICU tests. The average relationship between normalized shear moduli and single-amplitude shear strain that previously was suggested by Seed and Idriss (1970) for clay soils is shown in these figures for comparison. This relationship is only valid for specimens with initial isotropic consolidation and symmetric cyclic loading. Thus, comparison with the present results should only be made for tests with $K_{c}=1.0$. However, results from tests with $K_{c}=1.5$ and 2.0 are also shown on the diagrams.

Figures 39 and 40 show the results for intact soil. The shear moduli from the cyclic loading tests are normalized on the basis of the undrained shear strengths from UU tests in figure 39 , whereas the estimated values from ICU tests are used in figure 40 . Because only ICU values are available for the specimens used for resonant column tests, the best comparison is that shown in figure 40. The results from the cyclic loading tests with 


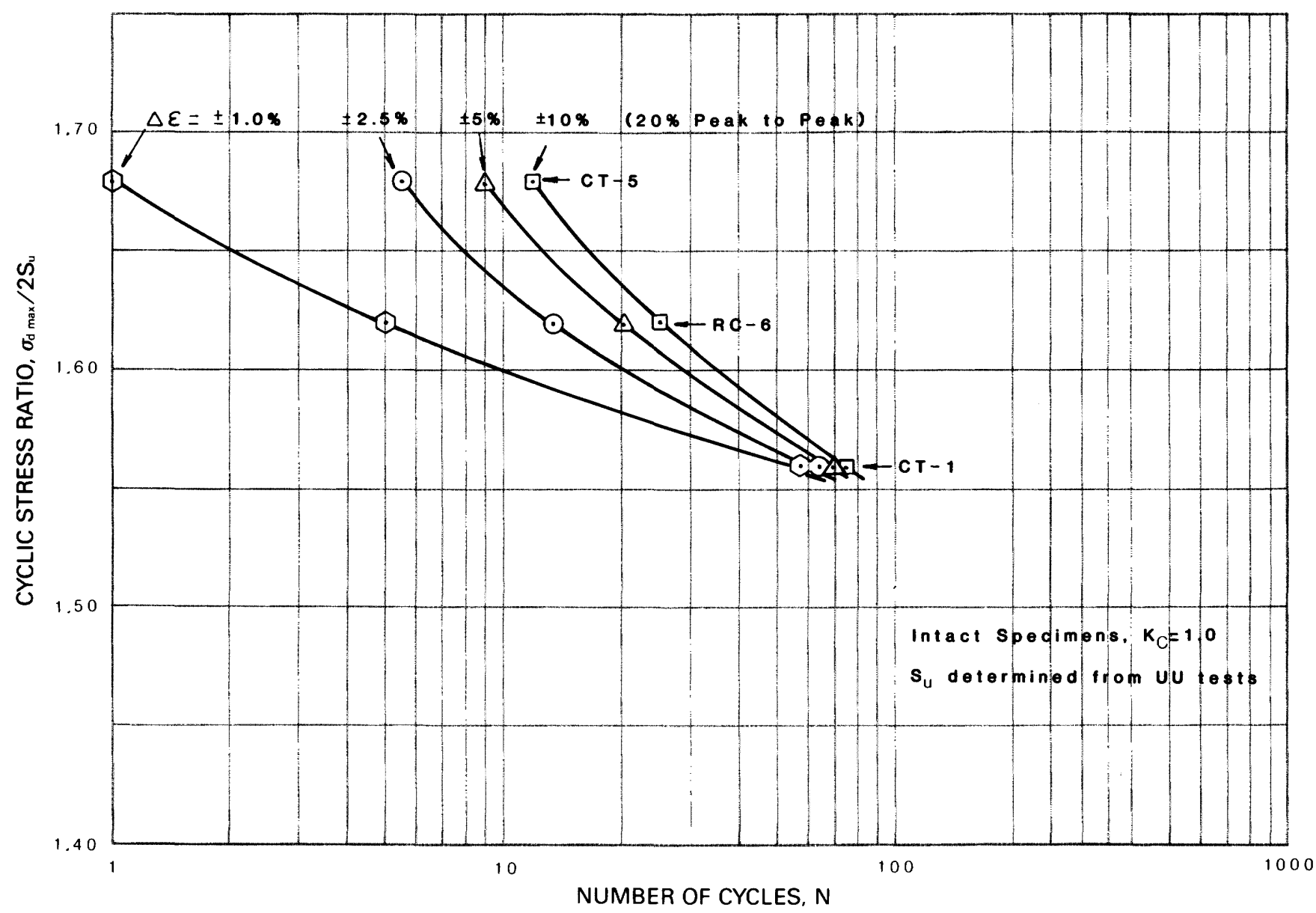

Figure 17. Cyclic stress ratio versus number of cycles for three intact specimens at initial consolidation ratio of 1.0 . Cyclic stress ratios determined from unconsolidated-undrained testing.

$K_{c}=1.0$ compare well with the Seed-Idriss relationship, whereas lower values of shear moduli are obtained from the resonant column tests (Updike and others, 1982) than those indicated by the Seed-Idriss relationship.

Figures 41 and 42 show similar results for remolded specimens. Very high values of normalized shear moduli are obtained when the remolded shear strengths from UU tests are used (fig. 41), whereas values comparable to the Seed-Idriss relationship are obtained on the basis of undrained shear strengths from ICU tests (fig. 42).

Direct comparison of shear moduli (not normalized) versus number of cycles for the intact and remolded specimens are shown on figures 43-45. Note that only results from the same sample may be directly compared in these figures. For a given low number of cycles, the shear modulus from the intact specimen is higher than that from the remolded specimen for conditions with $K_{c}=1.0$. At higher numbers of cycles the curves on figure 43 cross over each other, and the reverse relationship is obtained. Figures 44 and 45 show that the shear moduli are generally higher for remolded soil than for intact soil.

\section{Damping Ratios}

Damping ratios determined from the $\mathrm{X}-\mathrm{Y}$ recordings are given on figures 46 and 47 for intact and remolded specimens, respectively. The relationship proposed by Seed and Idriss (1970) is shown for comparison. The results of the resonant column tests form consistent relationships which are comparable to and within the range obtained by Seed and Idriss. The results from the cyclic loading tests show substantially more scatter. The majority of data points for $K_{c}=1.5$ and 2.0 indicate higher damping ratios than those obtained for $K_{c}=1.0$. The values obtained for $K_{c}=1.0$ scatter across the range suggested by Seed and Idriss with a considerable number of data points outside this range. 


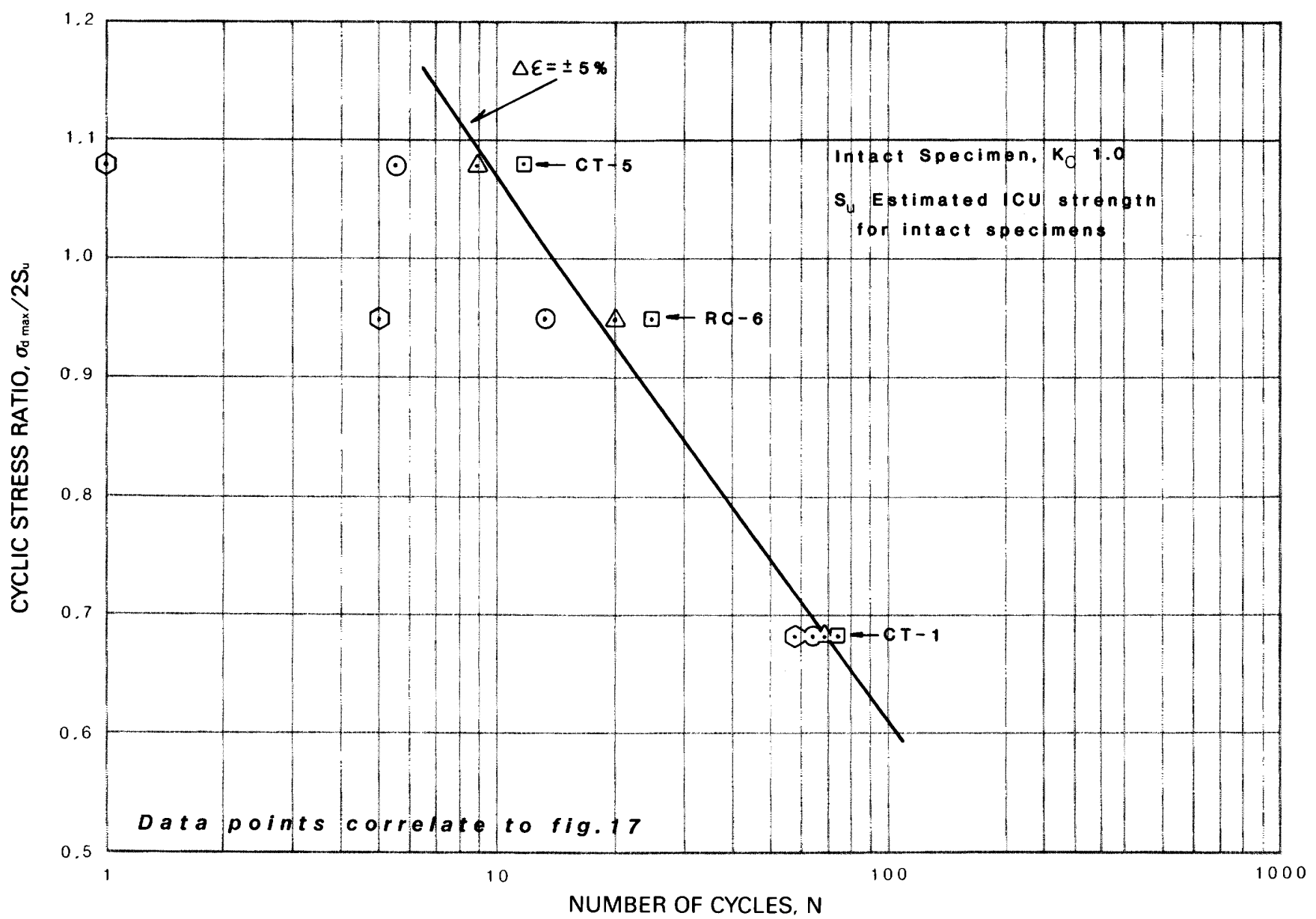

Figure 18. Cyclic stress ratio versus number of cycles for three intact specimens at initial consolidation ratio of 1.0 and using strength values estimated from isotropically undrained testing.

\section{SUMMARY AND CONCLUSIONS FROM LABORATORY TESTING}

Ten undisturbed samples of the Bootlegger Cove Formation (mainly facies II and IV) have been tested in an investigation of representative formational stress-strain and strength properties under static and cyclic loading conditions. Soil index tests were performed in this investigation to determine liquid and plastic limits, grain-size distributions, water contents, and densities. Static undrained strength tests such as torvane and unconsolidatedundrained triaxial compression tests were performed on intact and remolded specimens, whereas isotropically consolidated-undrained tests were performed on remolded specimens. Cyclic triaxial loading tests were performed on intact and remolded specimens with initial consolidation stress ratios of 1.0, 1.5, and 2.0. The static tests were performed to serve as background and basis for evaluation of the cyclic loading tests. The latter tests were performed to establish the number of cycles and cyclic stress ratios that are required to cause various amounts of strain, and to determine the magnitude and variation of the shear moduli and the damping ratios with single-amplitude shear strain.

The results of the cyclic loading tests indicate that higher cyclic stress ratios are required at higher consolidation stress ratios to cause a given amount of strain in a given number of cycles. Although the basis for comparison between results from intact and remolded specimens is questionable, it appears that they may have equivalent strengths. Although the data base is insufficient to provide completely conclusive statements to this effect, there is an indication that soils remolded in landslide areas have strengths equal to that of soils in areas that have not failed. This conclusion would significantly modify current concern in Anchorage for construction on old landslides.

The relationship between shear moduli and singleamplitude shear strain obtained from cyclic loading and resonant column tests shows a pattern similar to that suggested by Seed and Idriss (1970). The magnitudes of normalized shear moduli compare best with the Seed-Idriss 


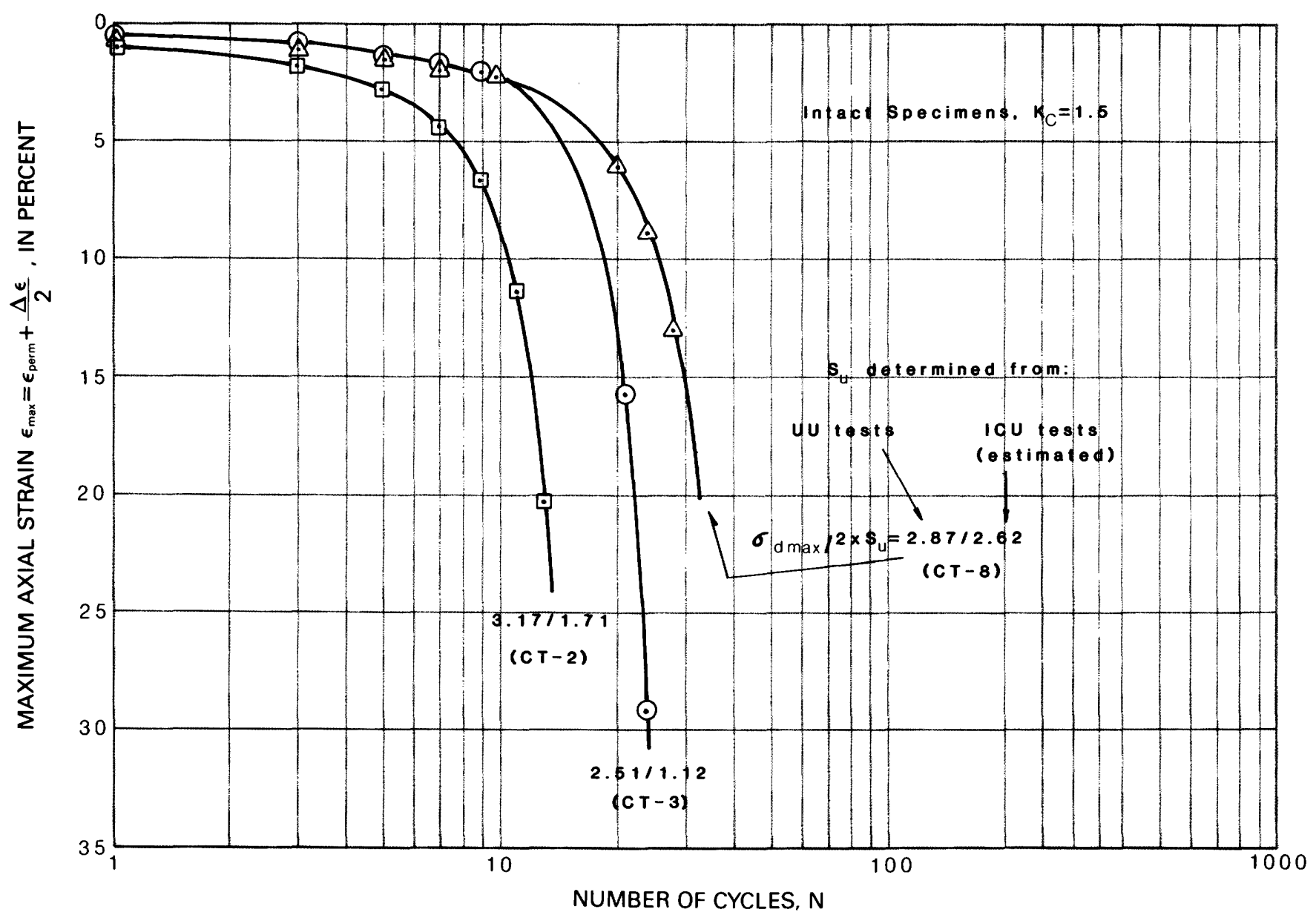

Figure 19. Maximum axial strain versus number of cycles for three intact specimens at initial consolidation stress ratios of 1.5 .

values when the experimental data are normalized on the basis of shear strengths obtained from isotropically consolidated-undrained shear tests (figs. 40, 42). The damping ratios from these tests show considerable scatter but generally follow the relationship proposed by Seed and Idriss (1970).

All the samples were collected from depths between 81 and $97 \mathrm{ft}$. The sediments in this interval were deposited during the quiet-water glaciolacustrine episode of accumulation of clay and silt. It is within this stratigraphic interval that the soil failures associated with the 1964 Prince William Sound earthquake are believed to have occurred (Shannon and Wilson, Inc., 1964; Updike, 1986). It should be noted that none of the samples tested yielded sensitivity values above 12 . As previously noted, concerns for sample disturbance effects manifest in the more unstable samples combined with the intent to characterize the "typical" cohesive facies of the formation dictated the range of sample types tested. Nevertheless, the sensitivity values, which are generally below 10 , pose the question as to whether the Bootlegger Cove Formation can be characterized as having soil horizons of ex- tremely high sensitivity that would fail under seismic loading. It may be shown by future testing that failurezone soils are collapsing or liquefying under a mechanism that is as yet poorly understood. If this is the case, then the traditional approach of assessing ground failure potential of the cohesive facies of the formation based strictly on sensitivity ratios is erroneous. In light of the fact that soils within the tested interval did fail in 1964, the test data reported here must be taken as a baseline for future assessment of ground failure potential in downtown Anchorage. Strength data determined from future testing that are significantly divergent from our data may identify the soils responsible for failure.

The foregoing presentation of data and intepretation is intended to "calibrate" the static and dynamic behavior of the cohesive facies of the Bootlegger Cove Formation. In order to further enhance this insight, a companion study should conduct static ICU tests on both intact and remolded soil in order to provide a common and consistent basis for comparison of results obtained from the cyclic loading tests. The emphasis of the study reported here was to conduct a carefully monitored 


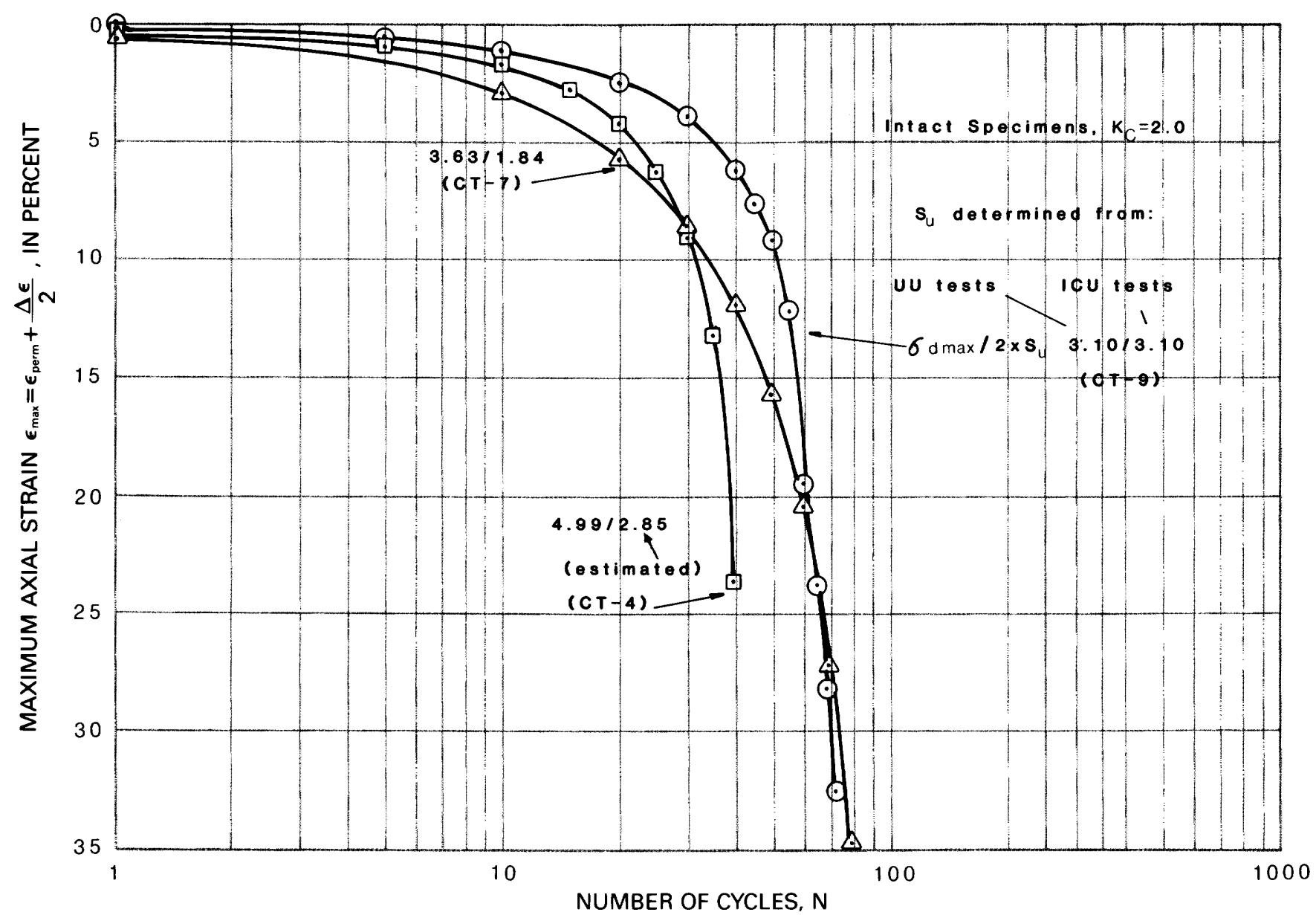

Figure 20. Maximum axial strain versus number of cycles for three intact specimens at initial consolidation stress ratios of 2.0.

sequence of static and dynamic triaxial tests on typical specimens of the Bootlegger Cove Formation. Highly sensitive specimens of facies F.III were intentionally avoided because the anticipated response of this facies would not benefit the objective of the study, which was to establish behavior norms for the predominant facies. The authors recommend that future investigations explore the comparative cyclic properties of each cohesive facies of the formation.

\section{REFERENCES CITED}

Bruhn, R.L., 1979, Holocene displacements measured by trenching the Castle Mountain Fault near Houston, Alaska: Alaska Division of Geological and Geophysical Surveys Geologic Report 61, p. 1-4.

Fogelman, K., Stephens, C., Lahr, J.C., Helton, S., and Allen, M., 1978, Catalog of earthquakes in southern Alaska, October-December, 1977: U.S. Geological Survey Open-File Report 78-1097, 28 p.
Hansen, W.R., 1965, Effects of the earthquake of March 27, 1964, at Anchorage, Alaska: U.S. Geological Survey Professional Paper 542-A, p. A1-A68.

Idriss, I.M., and Moriwaki, Yoshihaiu, 1982, Anchorage Office Complex geotechnical investigation, Anchorage, Alaska, v. 1, Seismic hazards evaluation: San Francisco, WoodwardClyde Consultants, p. 6-1 to 6-3.

Karlstrom, T.N.V., 1964, Quaternary geology of the Kenai Lowland and glacial history of the Cook Inlet Region, Alaska: U.S. Geological Survey Professional Paper 443, 69 p.

Kerr, P.F., and Drew, I.M., 1965, Quick clay movements, Anchorage, Alaska: Springfield, Va., National Technical Information Service, Document AD630-11, 133 p.

Lade, P.V., and Kirkgard, M.M., 1984, B-value tests for soil specimens with anisotropic stress states: American Society of Civil Engineers, 5th Engineering Mechanics Division Specialty Conference, Laramie, Wyoming, Proceedings, p. 1304-1307.

Lahr, J.C., Page, R.A., Stephens, C.D., and Fogleman, K.A., 1986, Sutton, Alaska, earthquake of 1984-evidence for activity on the Talkeetna segment of the Castle Mountain fault system: Seismological Society of America Bulletin, v. 76, p. $967-983$. 


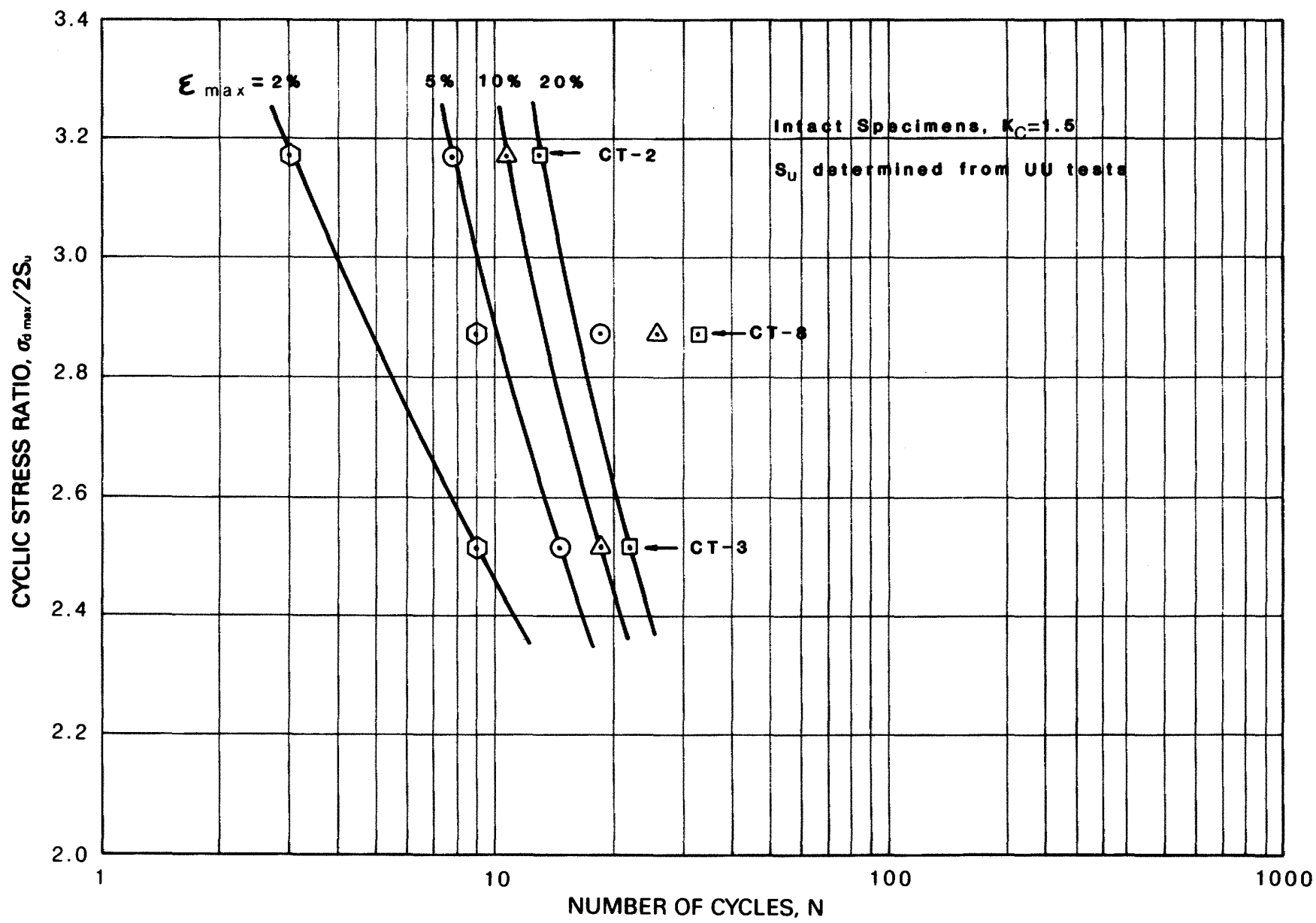

Figure 21. Cyclic stress ratio (determined from unconsolidated-undrained tests) versus number of cycles, for three intact specimens under initial consolidation ratio of 1.5 .

Lambe, T.W., and Whitman, R.V., 1979, Soil mechanics, SI version: New York, John Wiley, 553 p.

Miller, R.D., and Dobrovolny, E., 1959, Surficial geology of Anchorage and vicinity, Alaska: U.S. Geological Survey Bulletin 1093, 128 p.

Reger, R.D., and Updike, R.G., 1983, Upper Cook Inlet region and the Matanuska Valley, in Pewe, T.L., and Reger, R.D., Richardson and Glenn Highways-Guidebook to permafrost and Quaternary geology: Alaska Division of Geological and Geophysical Surveys Guidebook 1, p. 185-263.

Schmidt, R.A.M., 1963, Pleistocene marine microfauna in the Bootlegger Cove Clay, Anchorage Area, Alaska: Science, v. 141 , p. $350-351$.

Schmoll, H.R., and Dobrovolny, E., 1972, Generalized geologic map of Anchorage and vicinity, Alaska: U.S. Geological Survey Map I-787-A, scale 1:24,000, 1 sheet.

Schmoll, H.R., Szabo, B.J., Rubin, M., and Dobrovolny, E., 1972, Radiometric dating of marine shells from the Bootlegger Cove Clay, Anchorage area, Alaska: Geological Society of America Bulletin, v. 83, p. 1107-1114.

Seed, H.B., and Chan, C., 1964, Pulsating load tests on samples of clay and silt from Anchorage, Alaska, in Report on Anchorage area soil studies, to the U.S. Army Engineer District, Anchorage, Alaska: Seattle, Wash., 109 p.
Seed, H.B., and Idriss, I.M., 1970, Soil moduli and damping factors for dynamic response and analyses: University of California, Berkeley, Earthquake Engineering Research Institute Report No. 70-10, 34 p.

Seed, H.B., and Wilson, S.D., 1967, The Turnagain Heights landslide, Anchorage, Alaska: Journal of the Soil Mechanics and Foundation Division, American Society of Civil Engineers, v. 93, p. 325-353.

Shannon and Wilson, Inc., 1964, Report on Anchorage area soil studies, Alaska: Seattle, Wash., Shannon and Wilson, Inc., 109 p.

Updike, R.G., 1983, Seismic liquefaction potential in the Anchorage area, south-central Alaska: Geological Society of America Abstracts with Programs, v. 15, no. 5, p. 374.

1984, The Turnagain Heights landslide-an assessment using the electric cone penetration test: Alaska Division of Geological and Geophysical Surveys Report of Investigations 84-13, $48 \mathrm{p}$.

1986, Engineering geologic maps, Government Hill area, Anchorage, Alaska: U.S. Geological Survey Map I-1610, scale 1:4800, 1 sheet.

Updike, R.G., and Carpenter, B.A., 1986, Engineering geology of the Government Hill area, Anchorage, Alaska: U.S. Geological Survey Bulletin 1588, 32 p. 


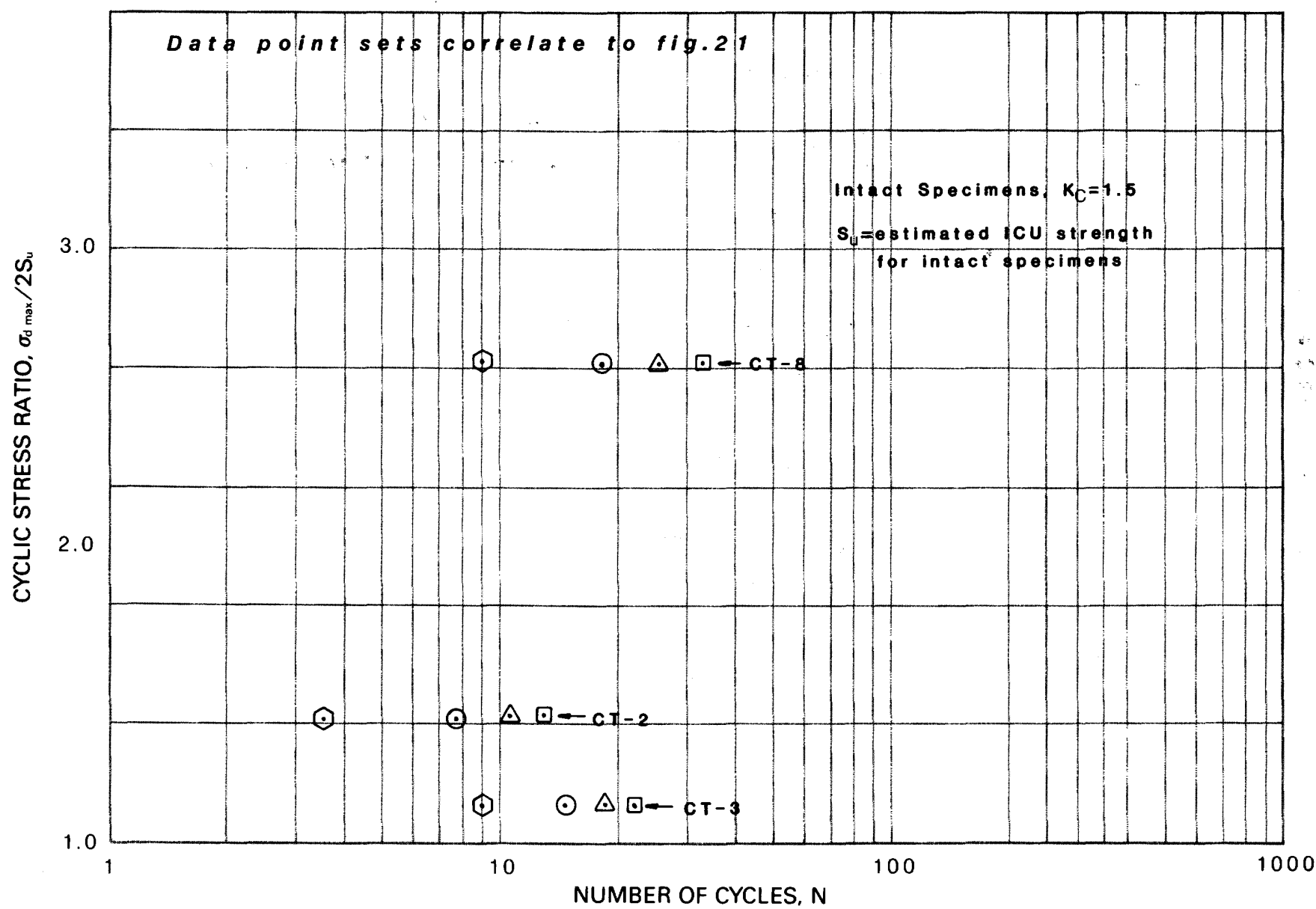

Figure 22. Cyclic stress ratio (estimated from isotropically consolidated-undrained tests) versus number of cycles, for three intact specimens under initial consolidation ratio of 1.5 .

Updike, R.G., Cole, D.A., and Ulery, C.A., 1982, Shear moduli and damping ratios for the Bootlegger Cove Formation as determined by resonant-column testing: Alaska Division of Geological and Geophysical Surveys Geologic Report 73, p. 7-12.
Updike, R.G., and Ulery, C.A., 1983, Preliminary geologic map of Anchorage B-6 NW (Eklutna Lake) Quadrangle: Alaska Division of Geological and Geophysical Surveys Geologic Report of Investigations 83-8, scale 1:10,000, 2 sheets. 


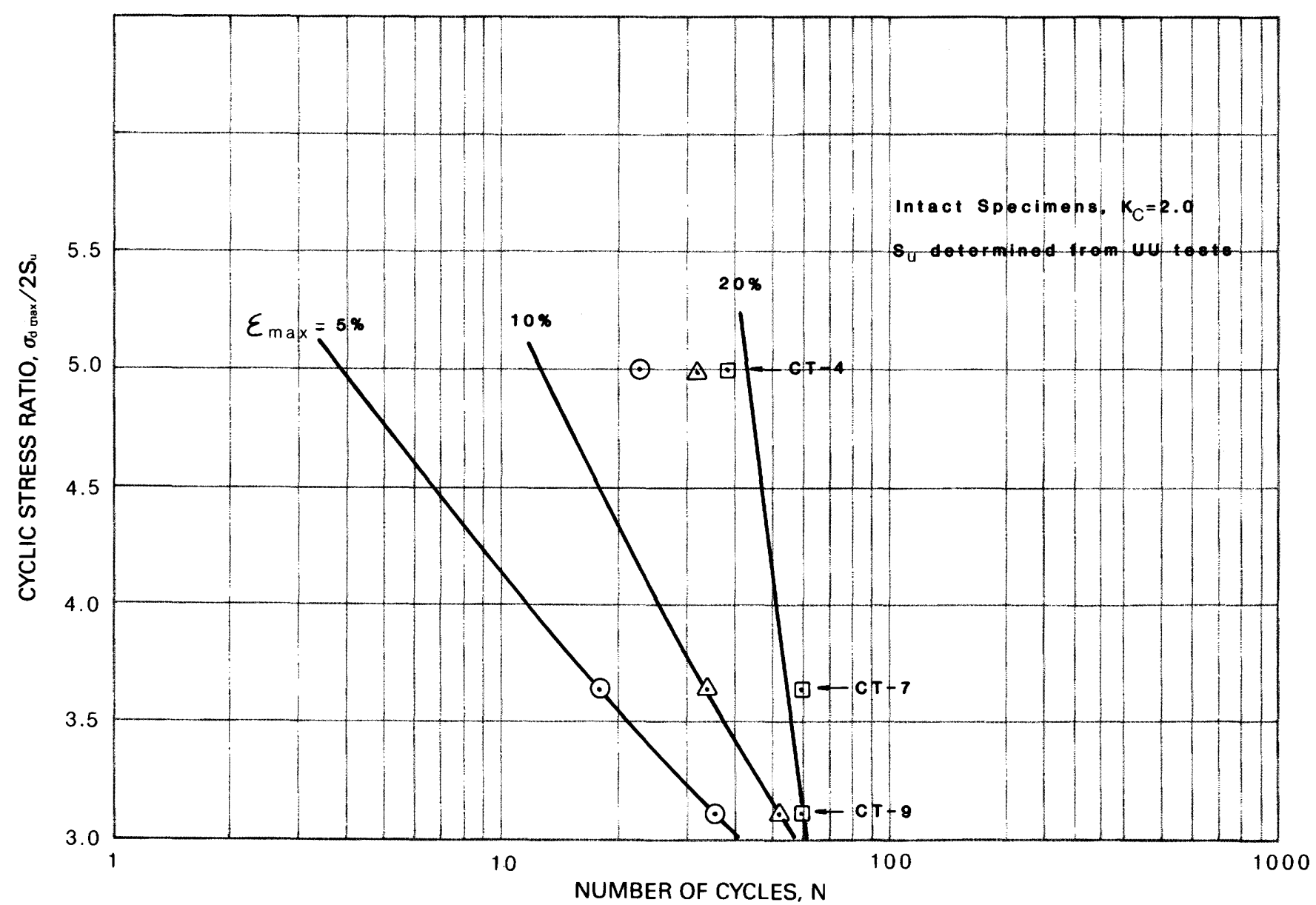

Figure 23. Cyclic stress ratio (determined from unconsolidated-undrained tests) versus number of cycles, for three intact specimens under initial consolidation ratio of 2.0 . 


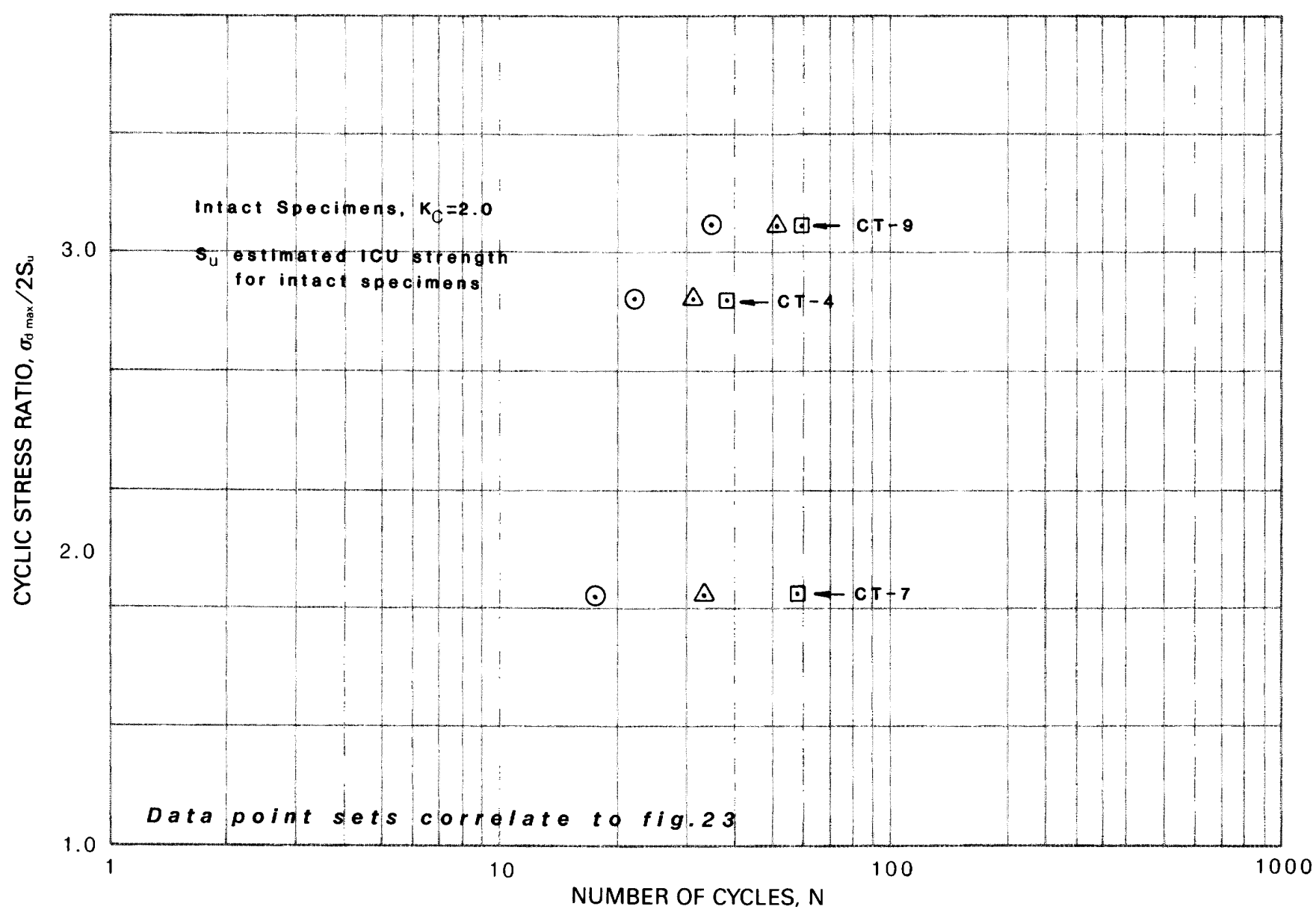

Figure 24. Cyclic stress ratio (estimated from isotropically consolidated-undrained tests) versus number of cycles, for three intact specimens, all at initial consolidation ratios of 2.0 . 


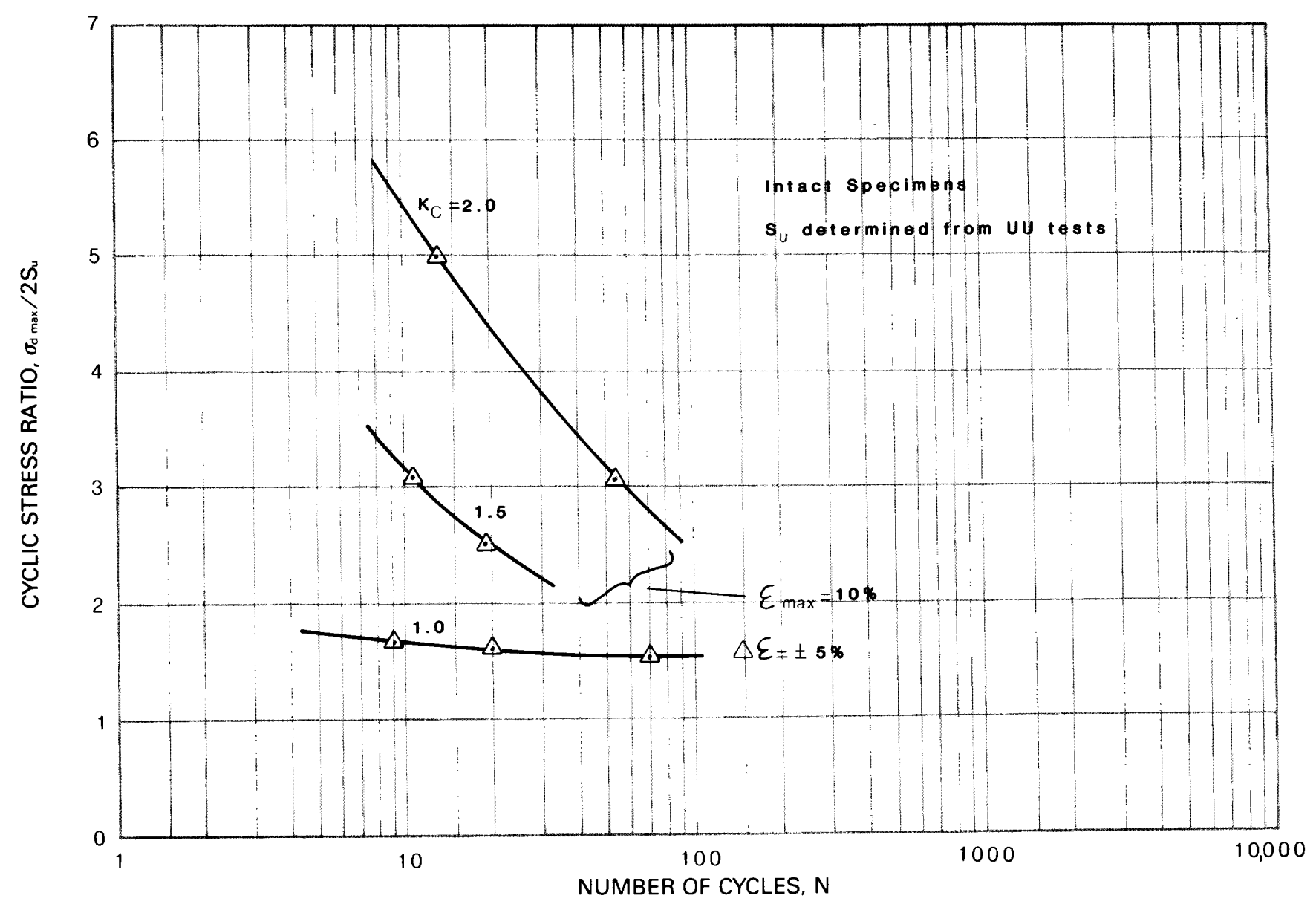

Figure 25. Cyclic stress ratio versus number of cycles for seven intact specimens at consolidation ratios of 1.0, 1.5, and 2.0. Maximum strains of 5 percent (for $K_{c}=1.0$ ) and 10 percent (for $K_{c}=1.5$ and 2.0) were taken from figures 17, 21, and 23, which were based on unconsolidated-undrained tests. 


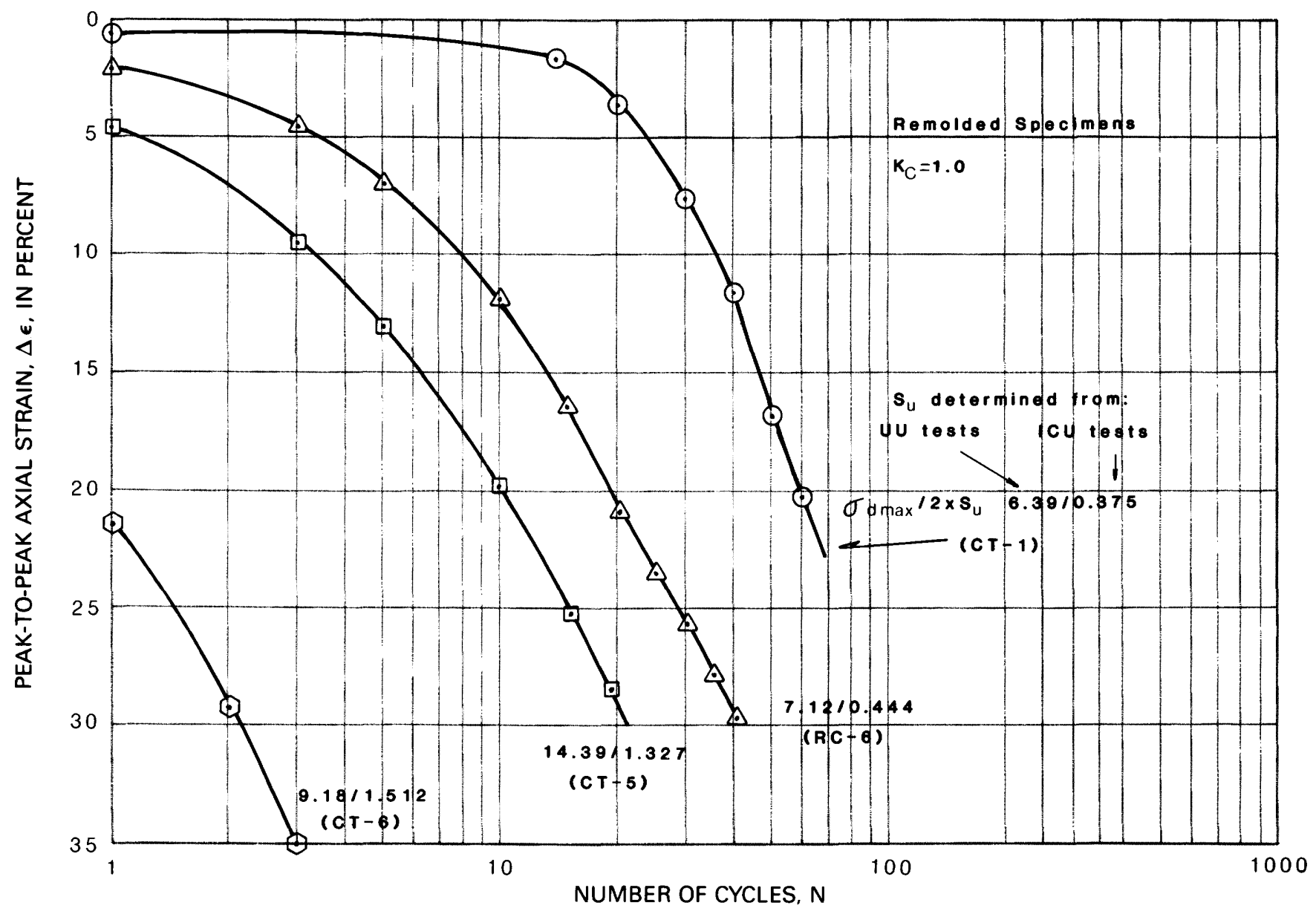

Figure 26. Peak-to-peak axial strain versus number of cycles for four remolded specimens, all at initial consolidation ratios of 1.0. 


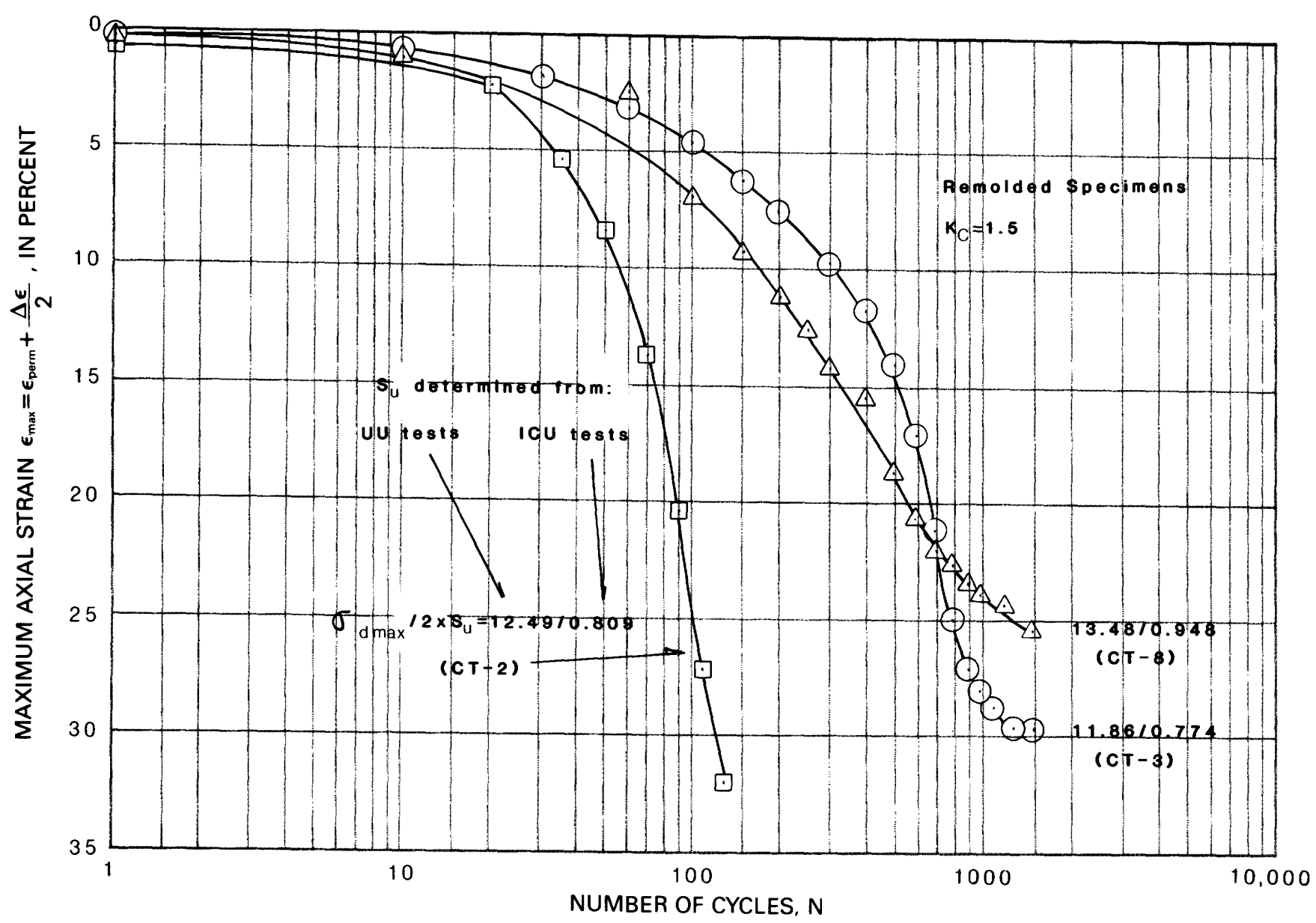

Figure 27. Maximum axial strain versus number of cycles for three remolded specimens, all at initial consolidation ratios of 1.5. 


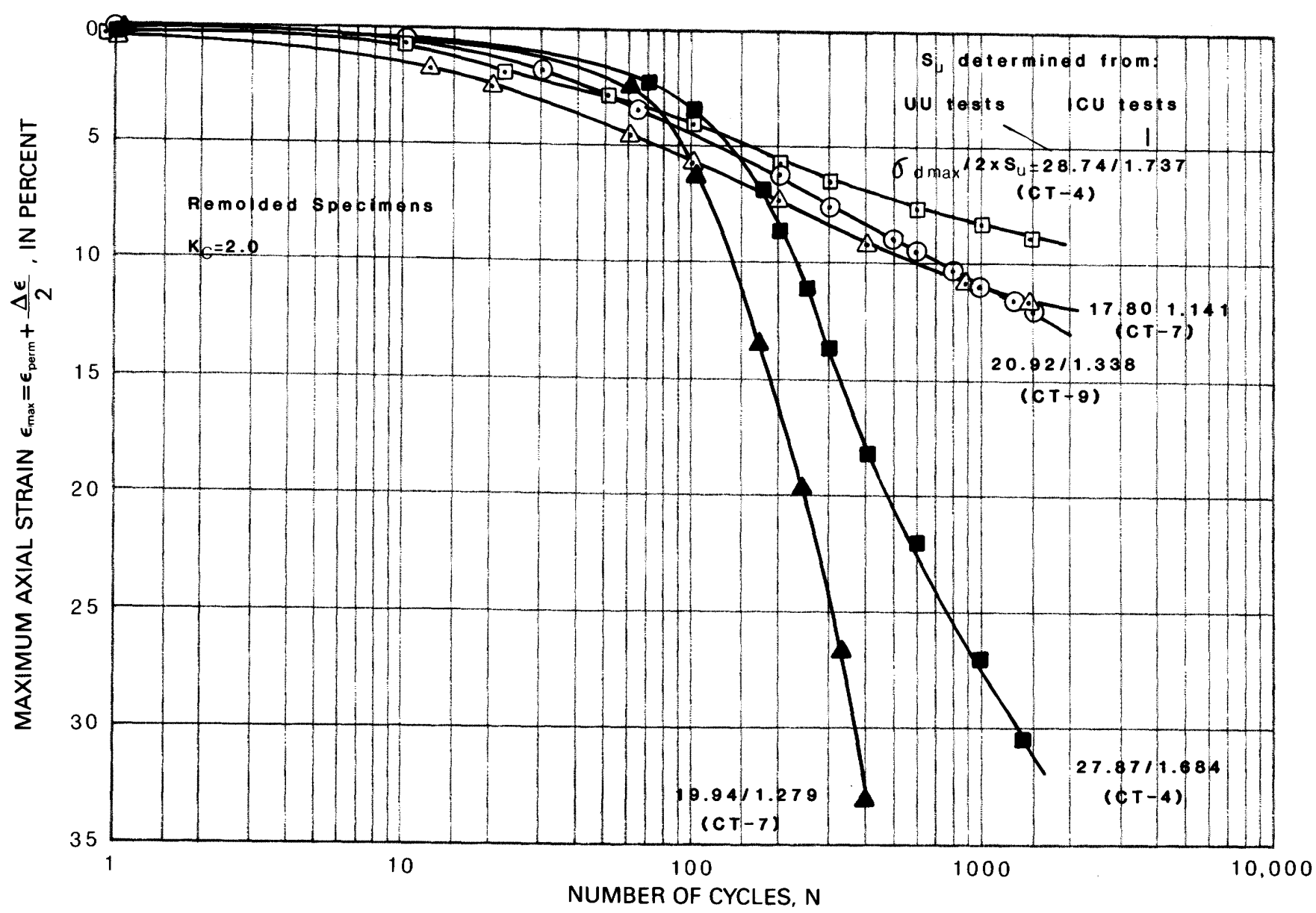

Figure 28. Maximum axial strain versus number of cycles for five remolded specimens, all at initial consolidation ratios of 2.0. 


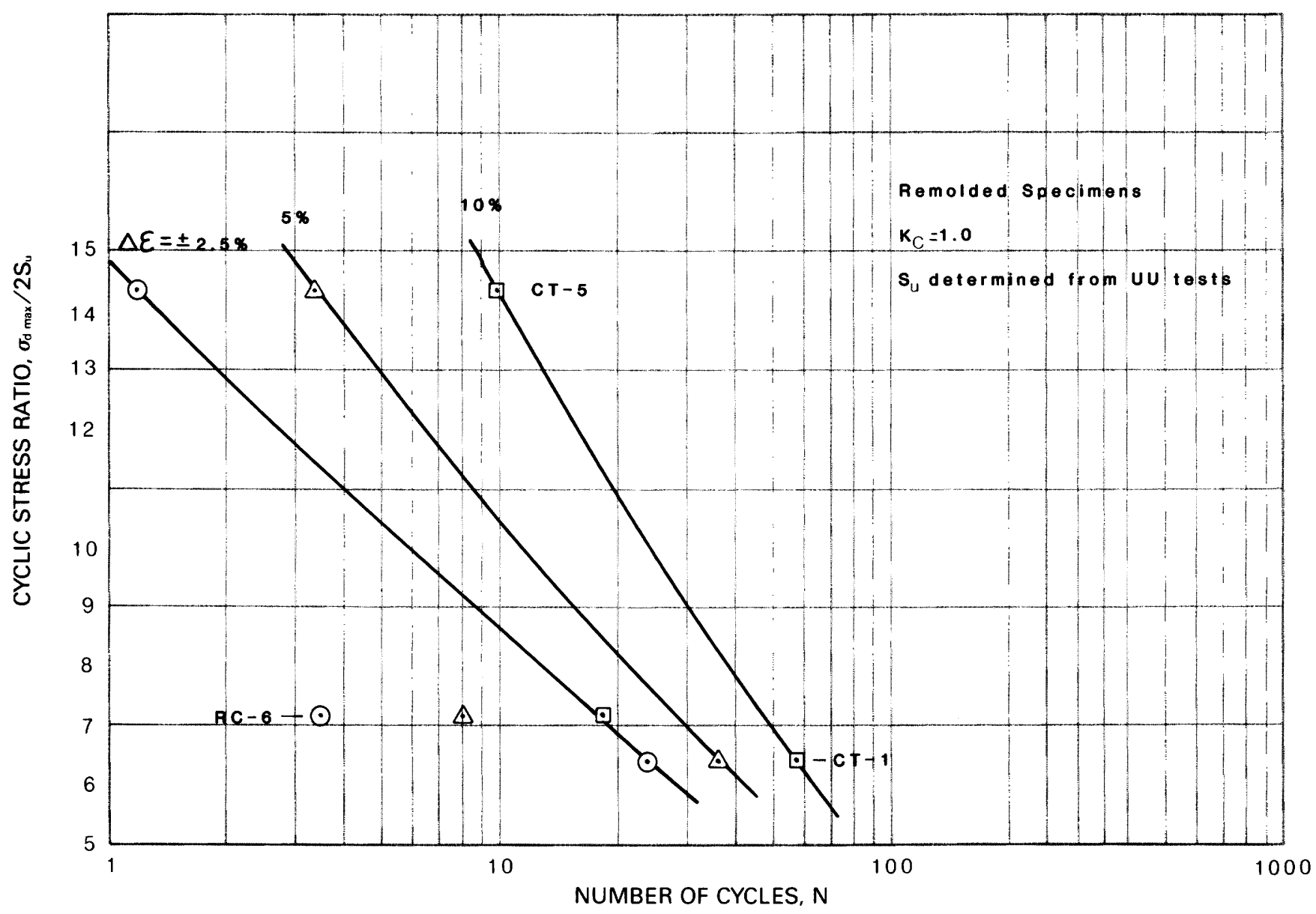

Figure 29. Cyclic stress ratio (determined using unconsolidated-undrained tests) versus number of cycles, for three remolded specimens, under initial consolidation ratios of 1.0 . 


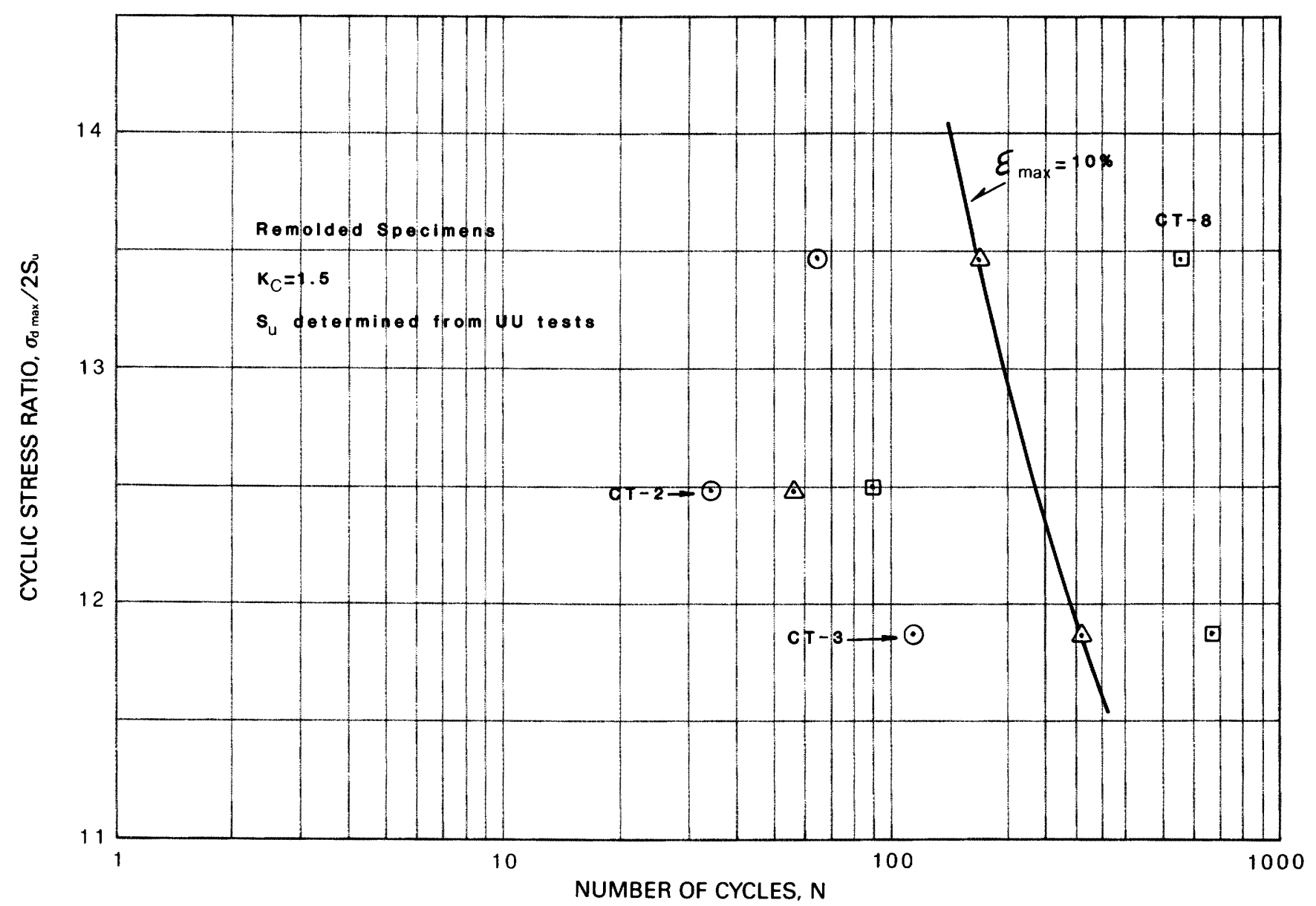

Figure 30. Cyclic stress ratio (determined using unconsolidated-undrained tests) versus number of cycles, for three remolded specimens, under initial consolidation ratios of 1.5 . 


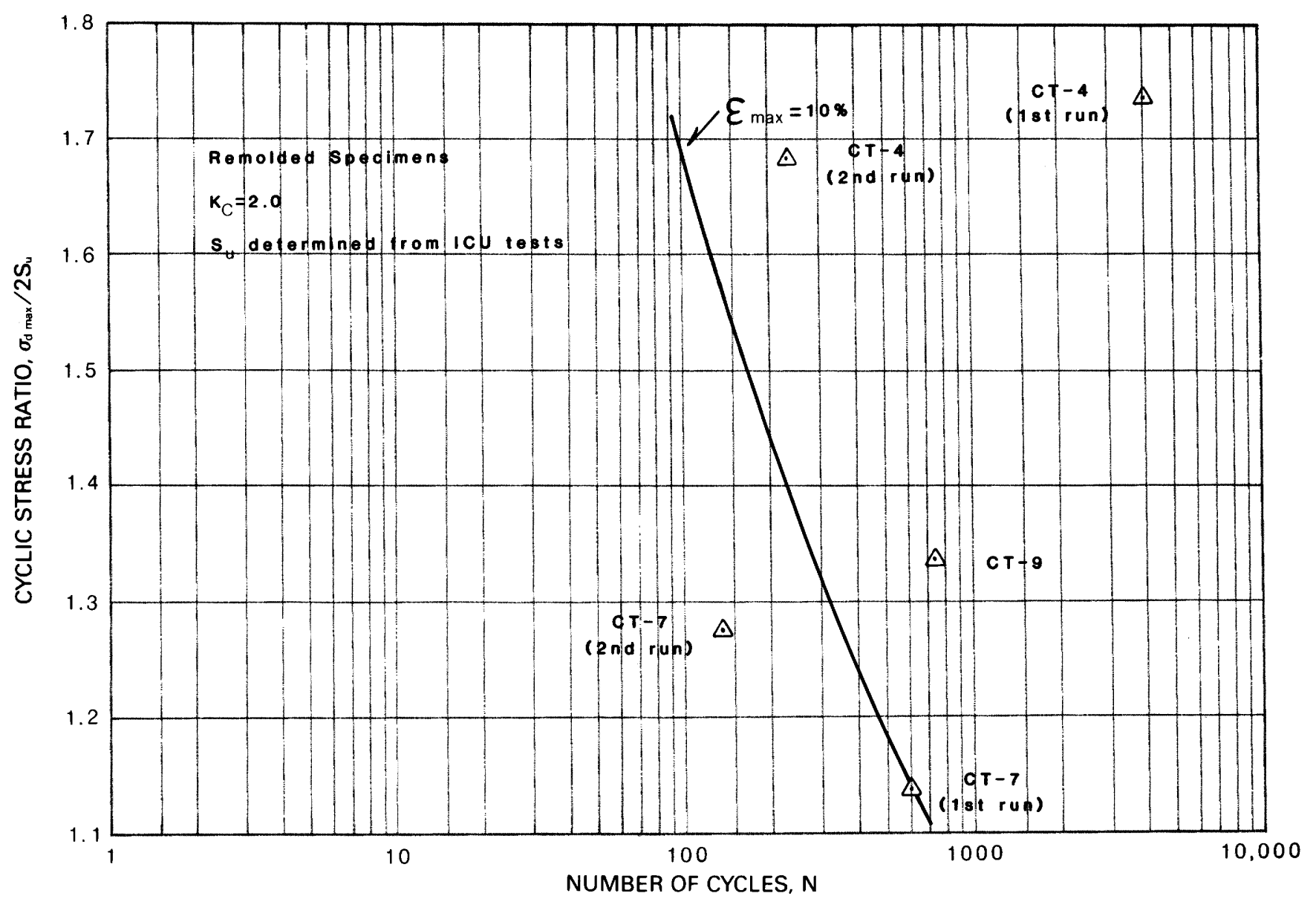

Figure 31. Cyclic stress ratio (determined using unconsolidated-undrained tests) versus number of cycles, for four remolded specimens, under initial consolidation ratios of 2.0 . 


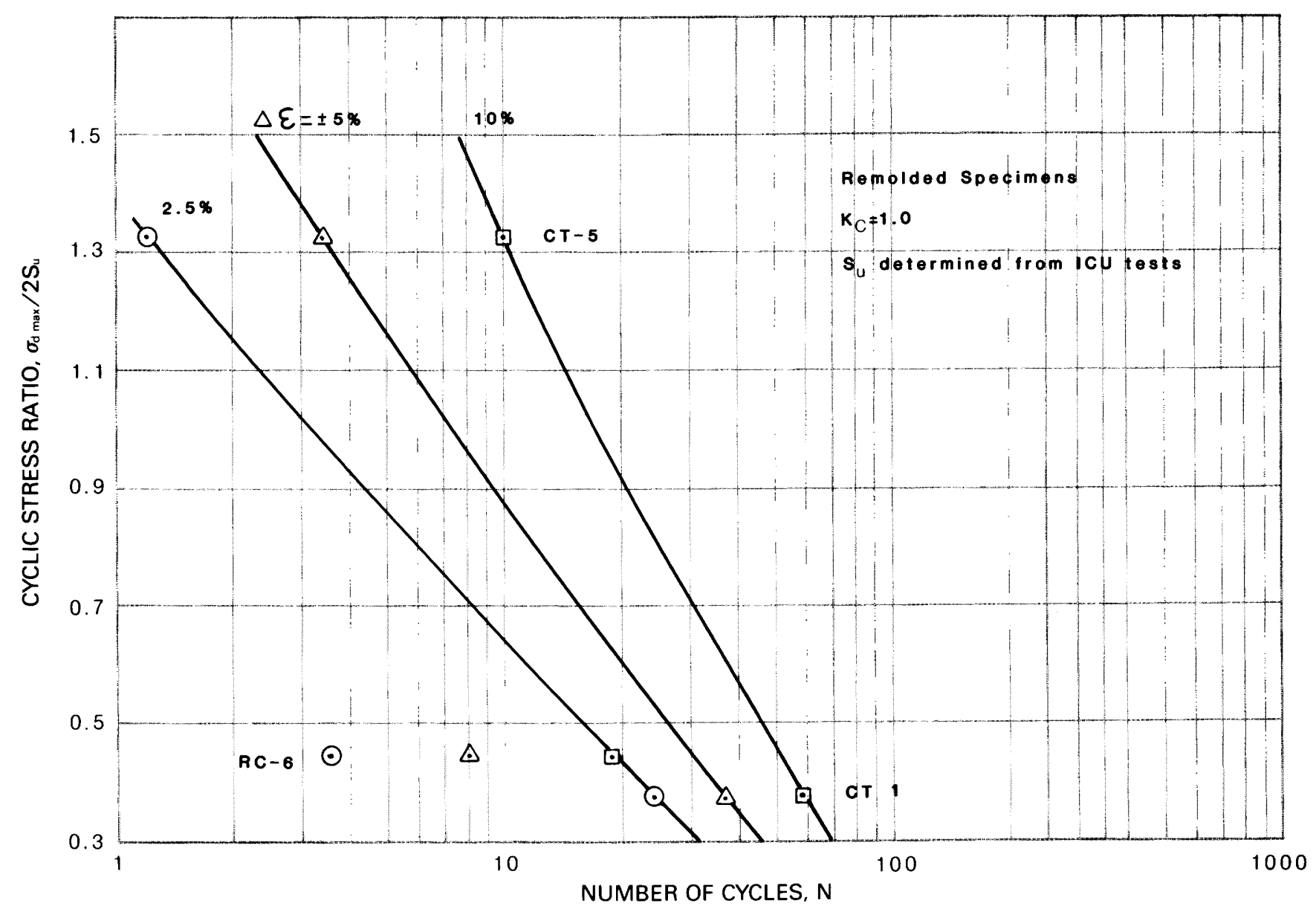

Figure 32. Cyclic stress ratio (determined using isotropically consolidated-undrained tests) versus number of cycles, for three remolded specimens, under initial consolidation ratios of 1.0 . 


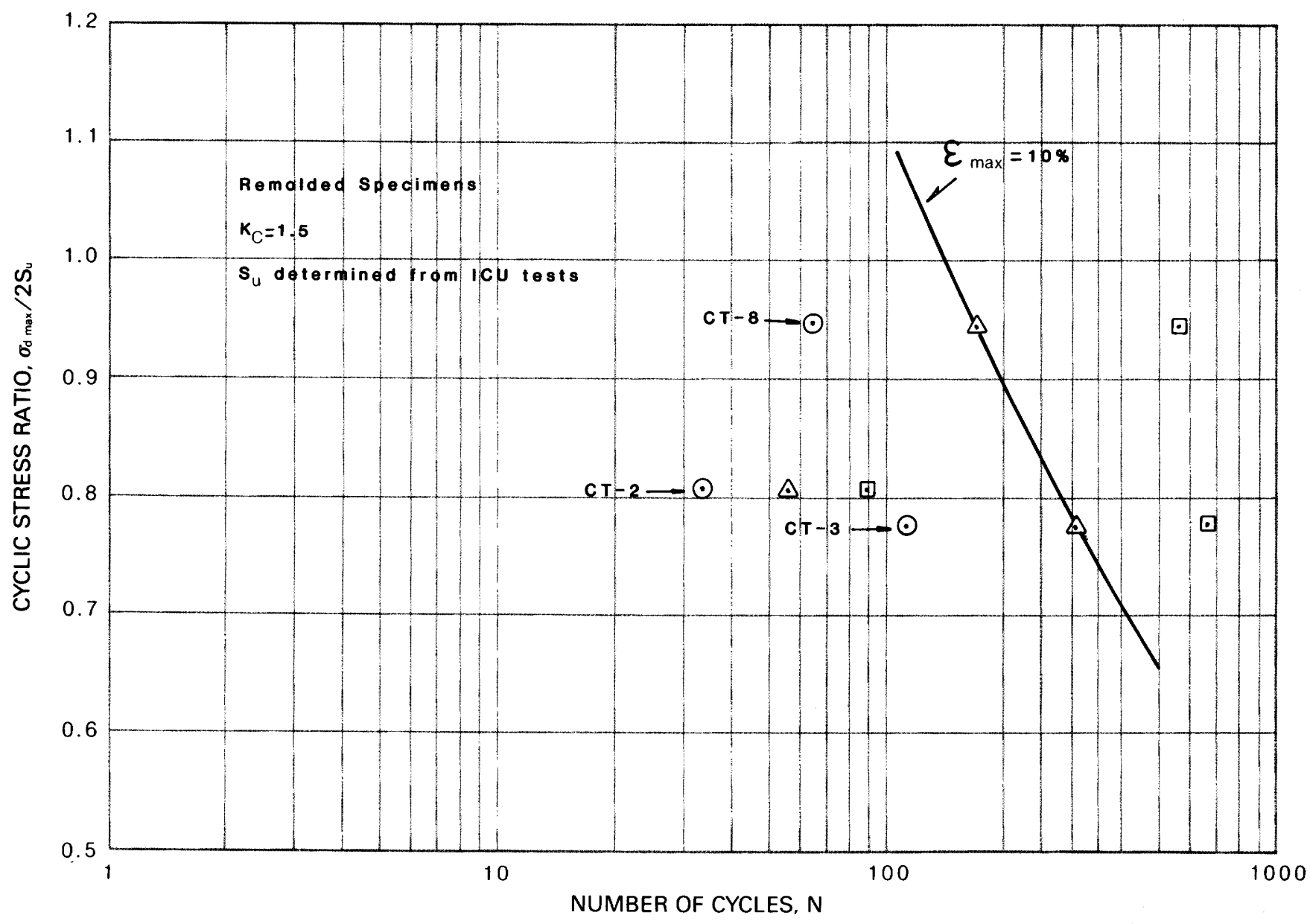

Figure 33. Cyclic stress ratio (determined using isotropically consolidated-undrained tests) versus number of cycles for three remolded specimens, under initial consolidation ratios of 1.5. 


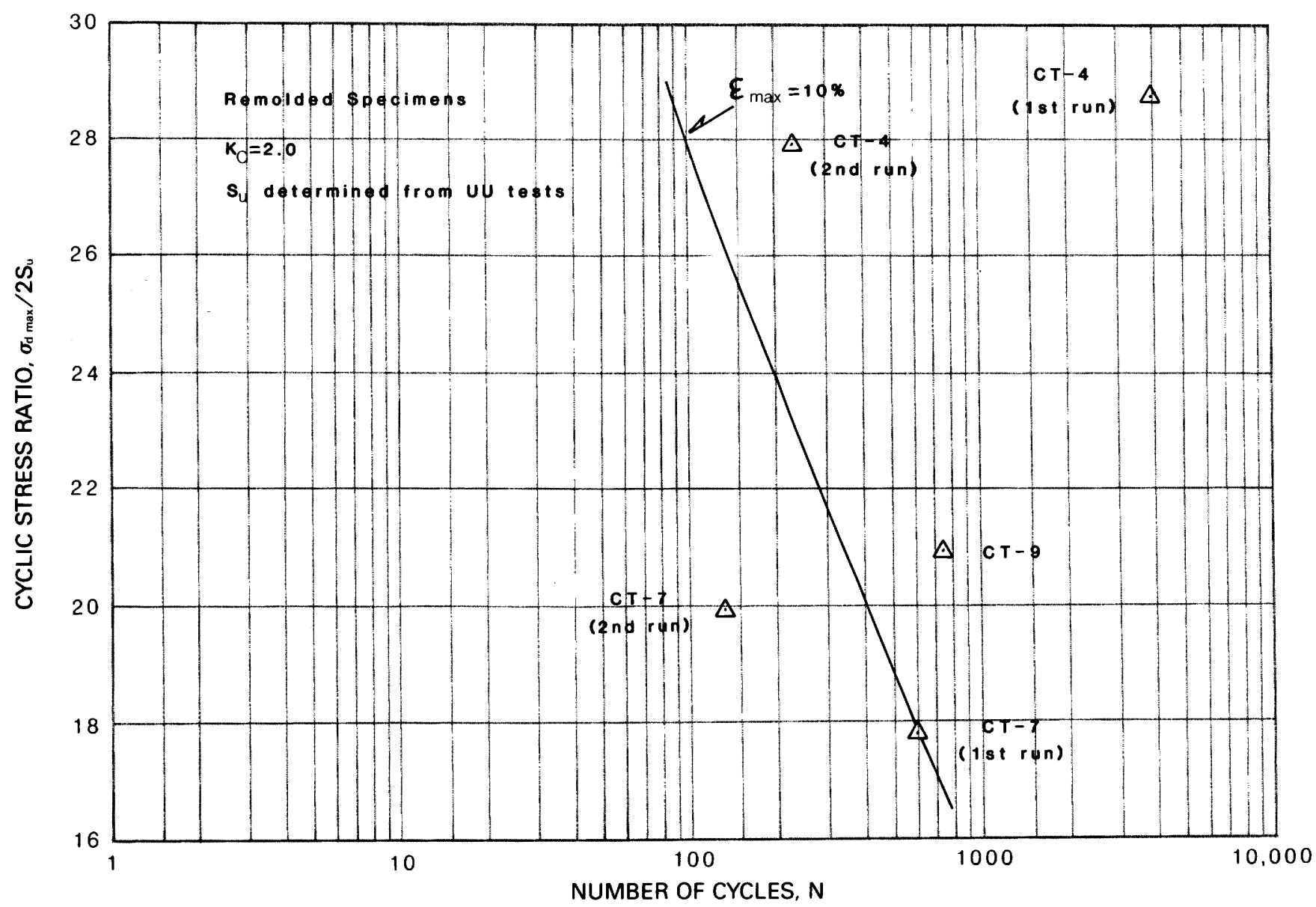

Figure 34. Cyclic stress ratio (determined using isotropically consolidated-undrained tests) versus number of cycles for four remolded specimens, under initial consolidation ratios of 2.0 . 


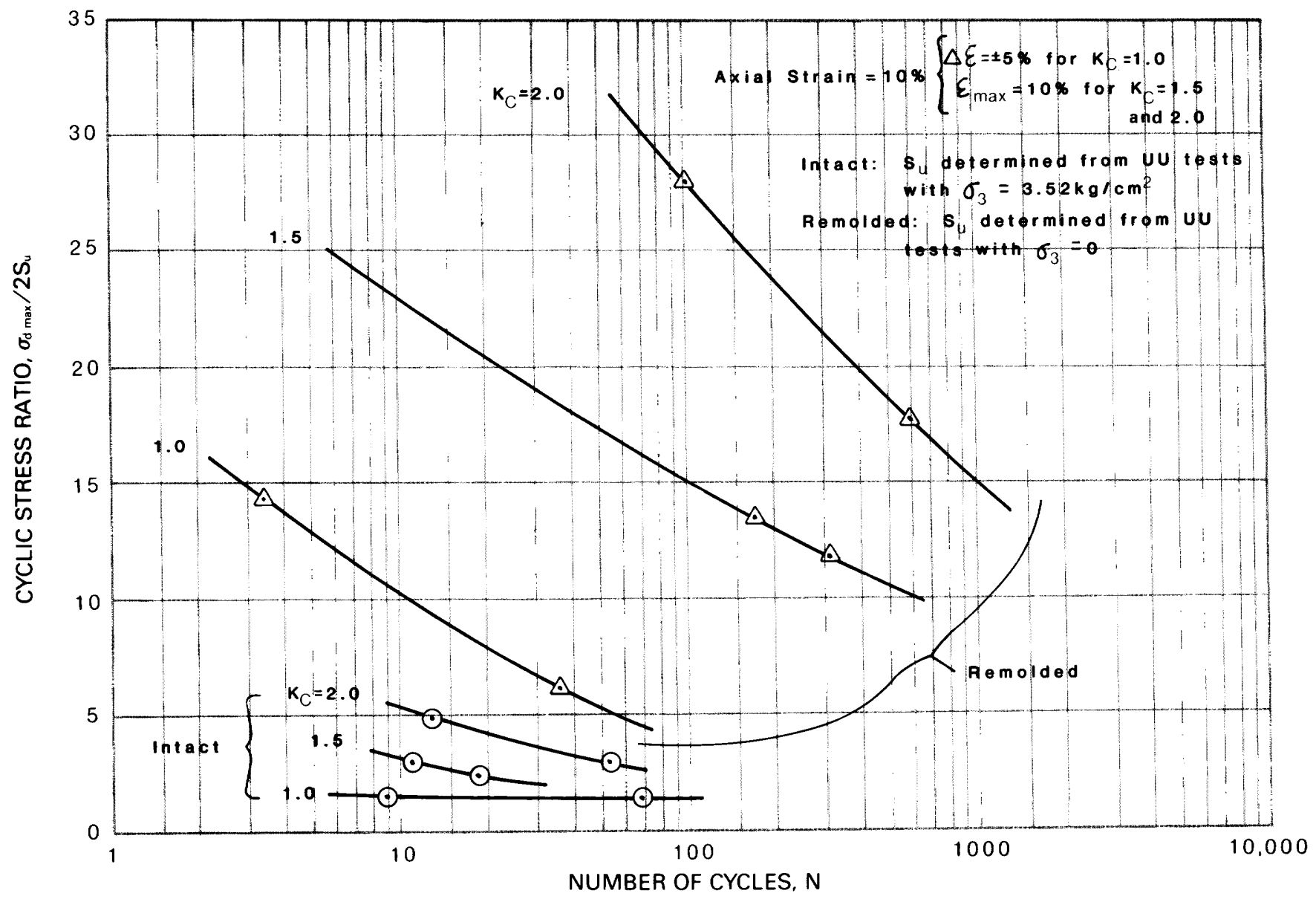

Figure 35. Cyclic stress ratio versus number of cycles for six remolded specimens at consolidation ratios of $1.0,1.5$, and 2.0 . Axial strains of 5 percent (for $K_{c}=1.0$ ) and 10 percent (for $K_{c}=1.5$ and 2.0) were taken from figures 29, 30, and 31 (UU tests). Curves for intact specimens, as shown in figure 25 , are given for comparison. 


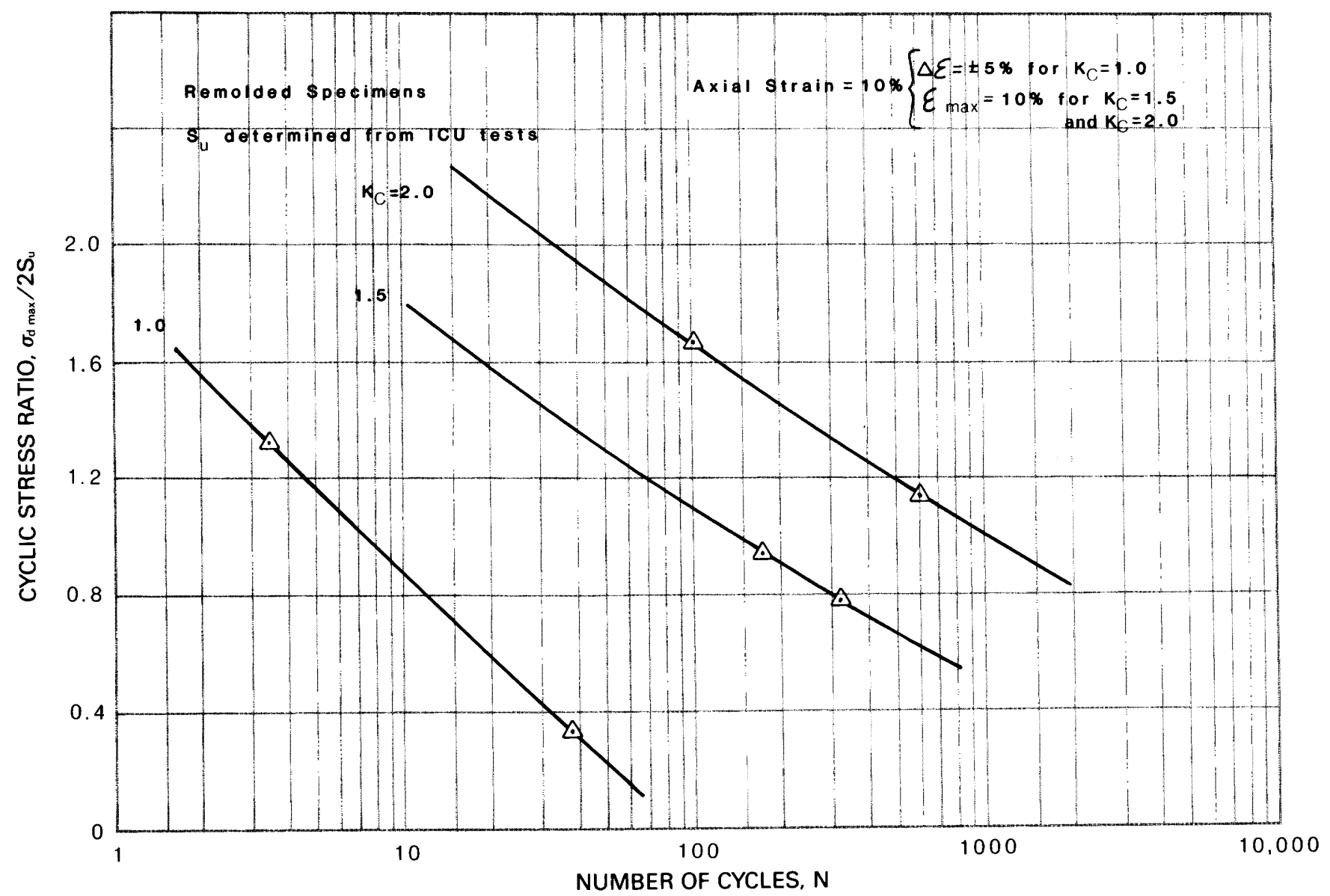

Figure 36. Cyclic stress ratio versus number of cycles for remolded specimens at $K_{c}=1.0,1.5$, and 2.0, based upon shear strengths determined by isotropically consolidated-undrained conditions. 


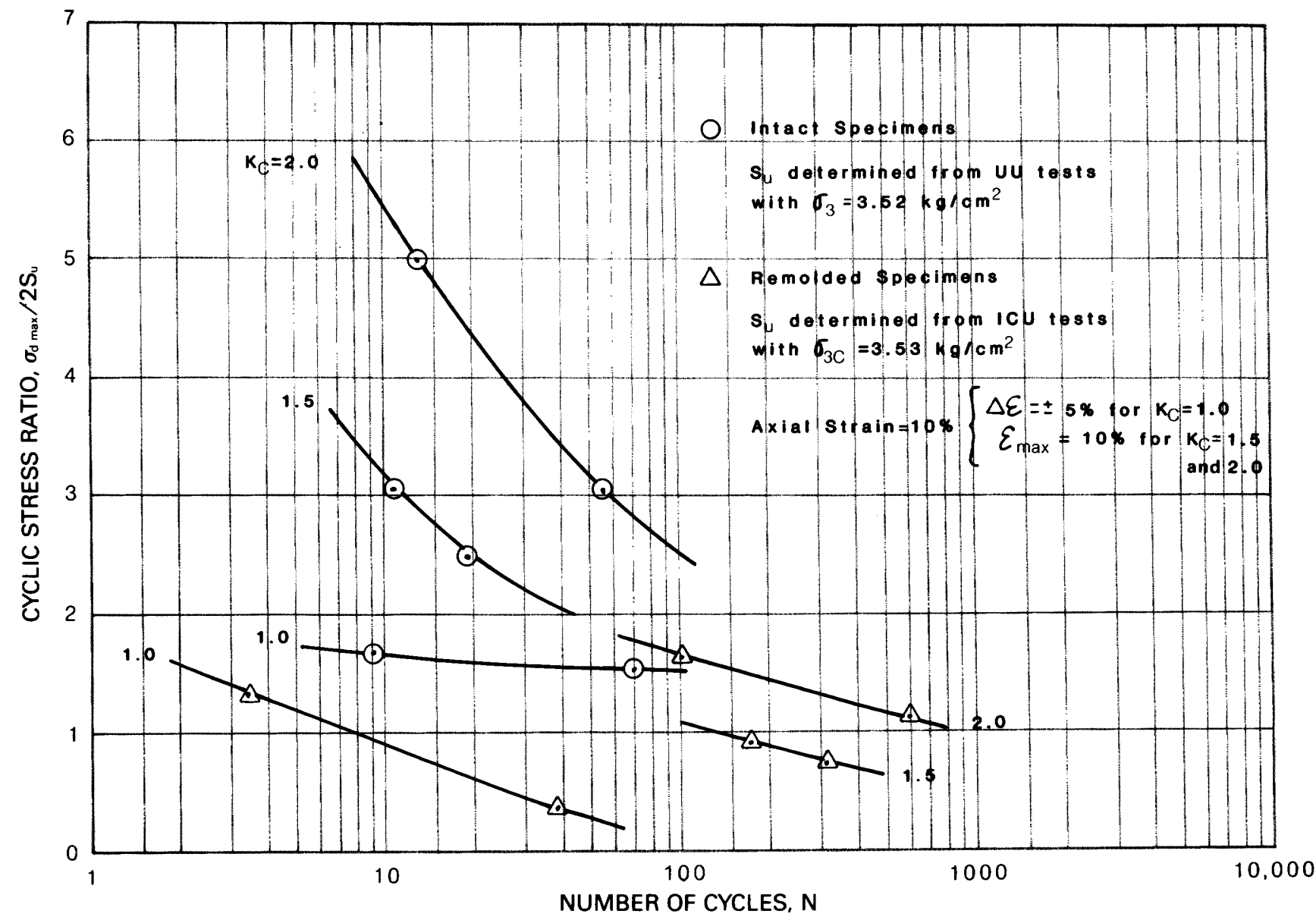

Figure 37. A comparison of cyclic stress ratios for intact specimens (determined from unconsolidated-undrained tests) with ratios of remolded specimens (determined from isotropically consolidated-undrained tests). Note apparent lower strength of remolded specimens at all consolidation ratios. 


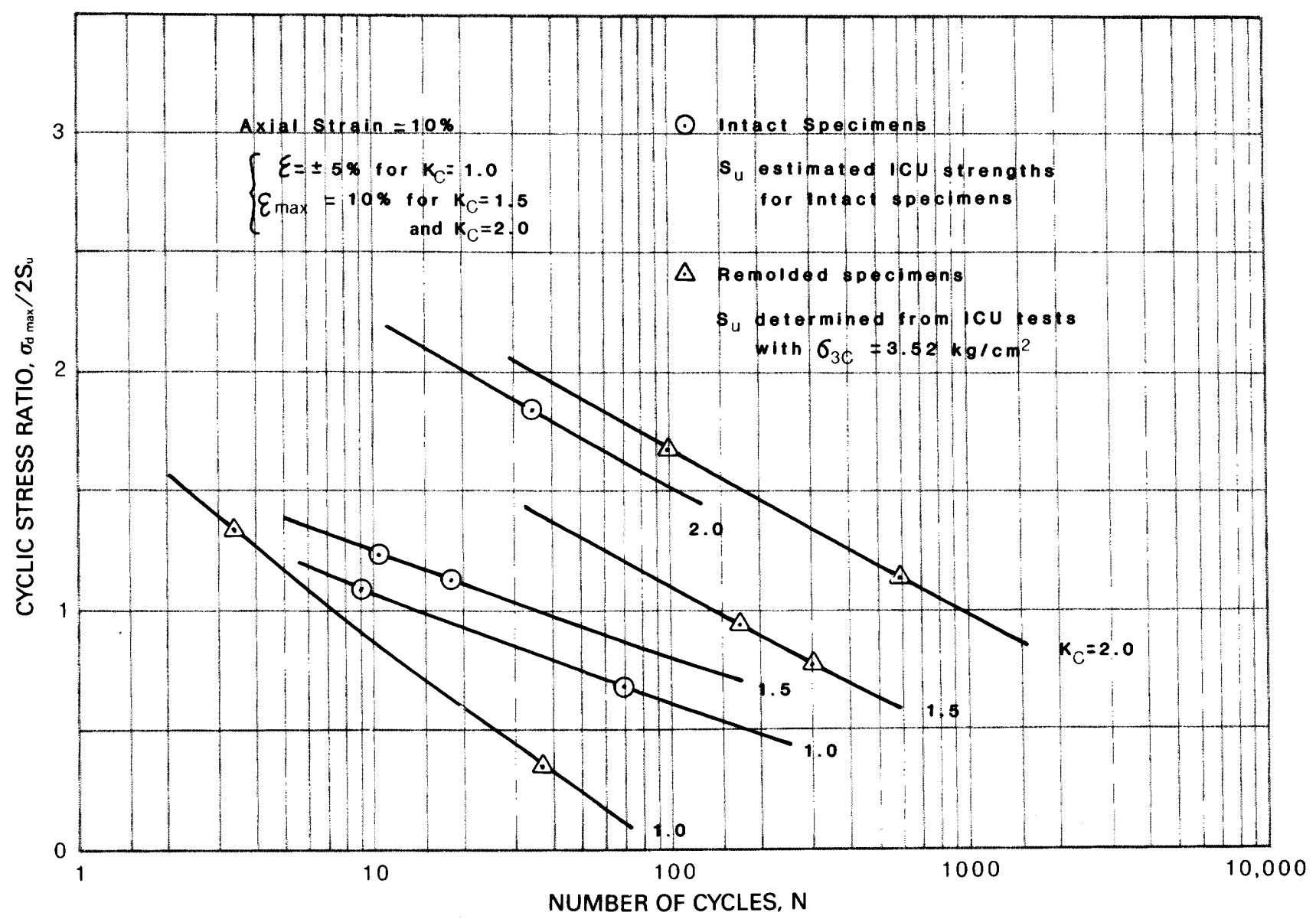

Figure 38. A comparison of cyclic stress ratios for intact specimens (estimated from isotropically consolidated-undrained (ICU) tests) with ratios for remolded specimens (measured from ICU tests). In contrast to figure 37, a much closer agreement in strength between intact and remolded specimens is shown in this graph. 


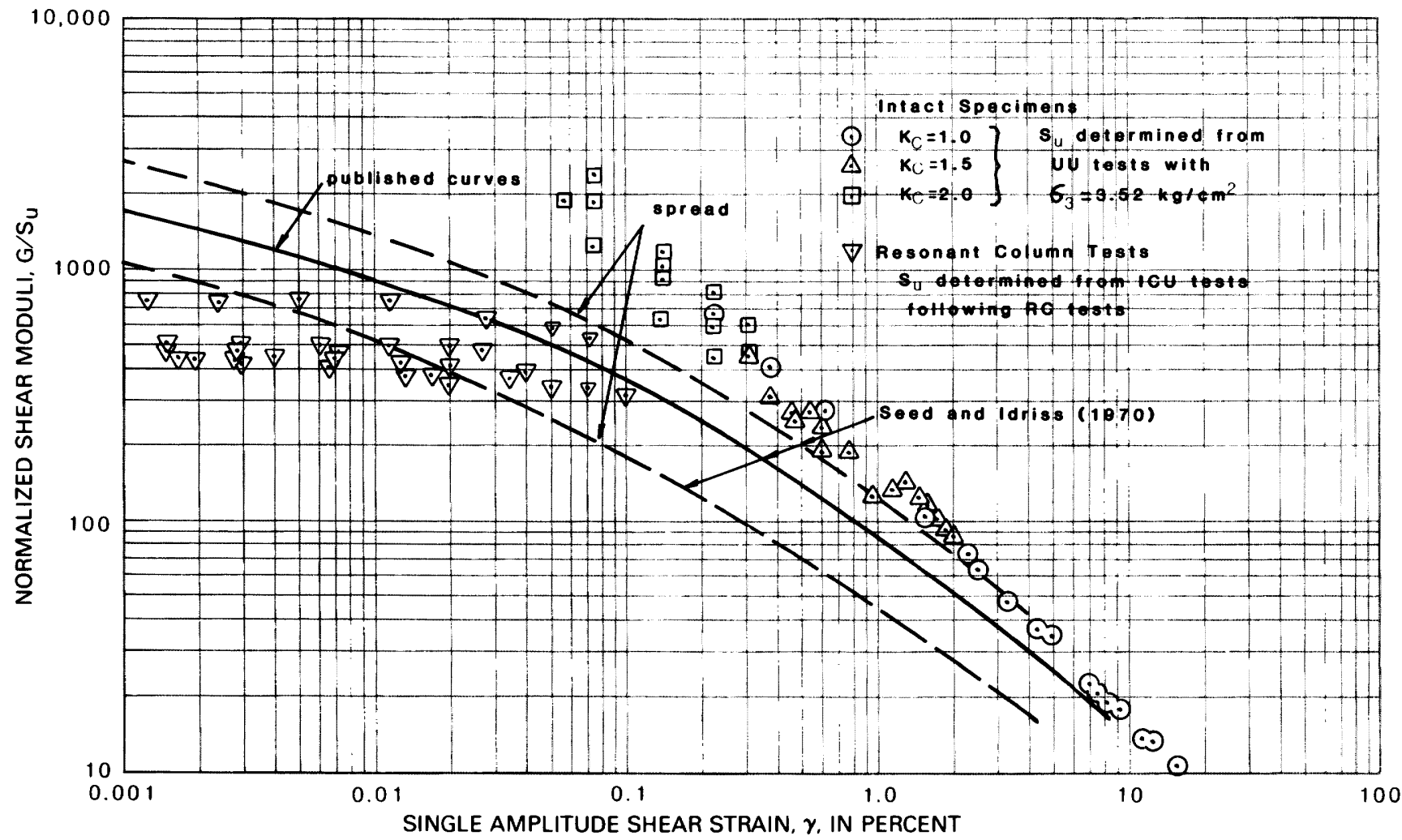

Figure 39. Normalized shear moduli for intact specimens using shear strengths determined by unconsolidated-undrained tests. Also shown are moduli results from resonant column tests (see Updike and others, 1982) and normalized curves from Seed and Idriss (1970).

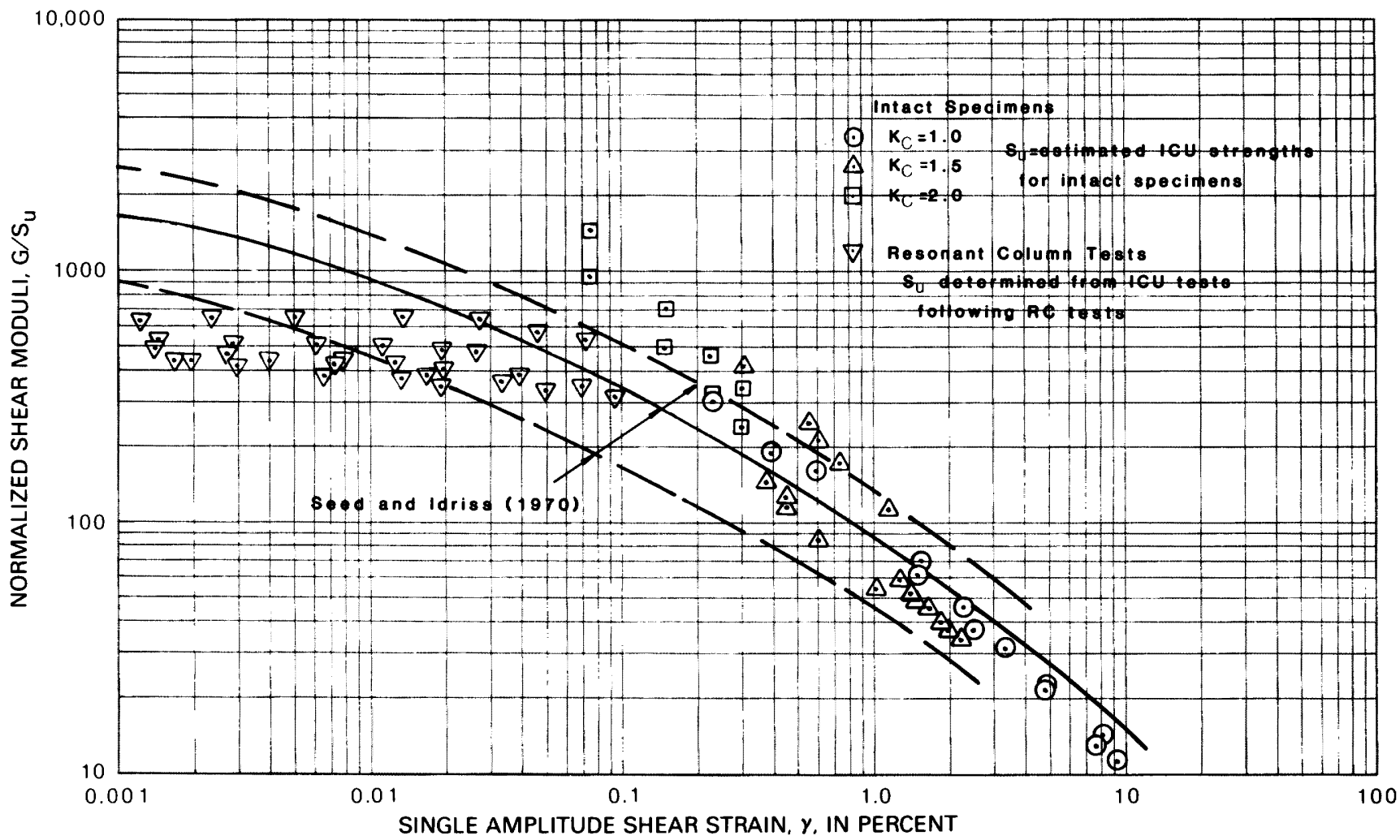

Figure 40. Normalized shear moduli for intact specimens using shear strengths determined by estimates of isotropically consolidated-undrained shear tests. Also shown are moduli results from resonant column tests (see Updike and others, 1982) and normalized curves from Seed and Idriss (1970). 


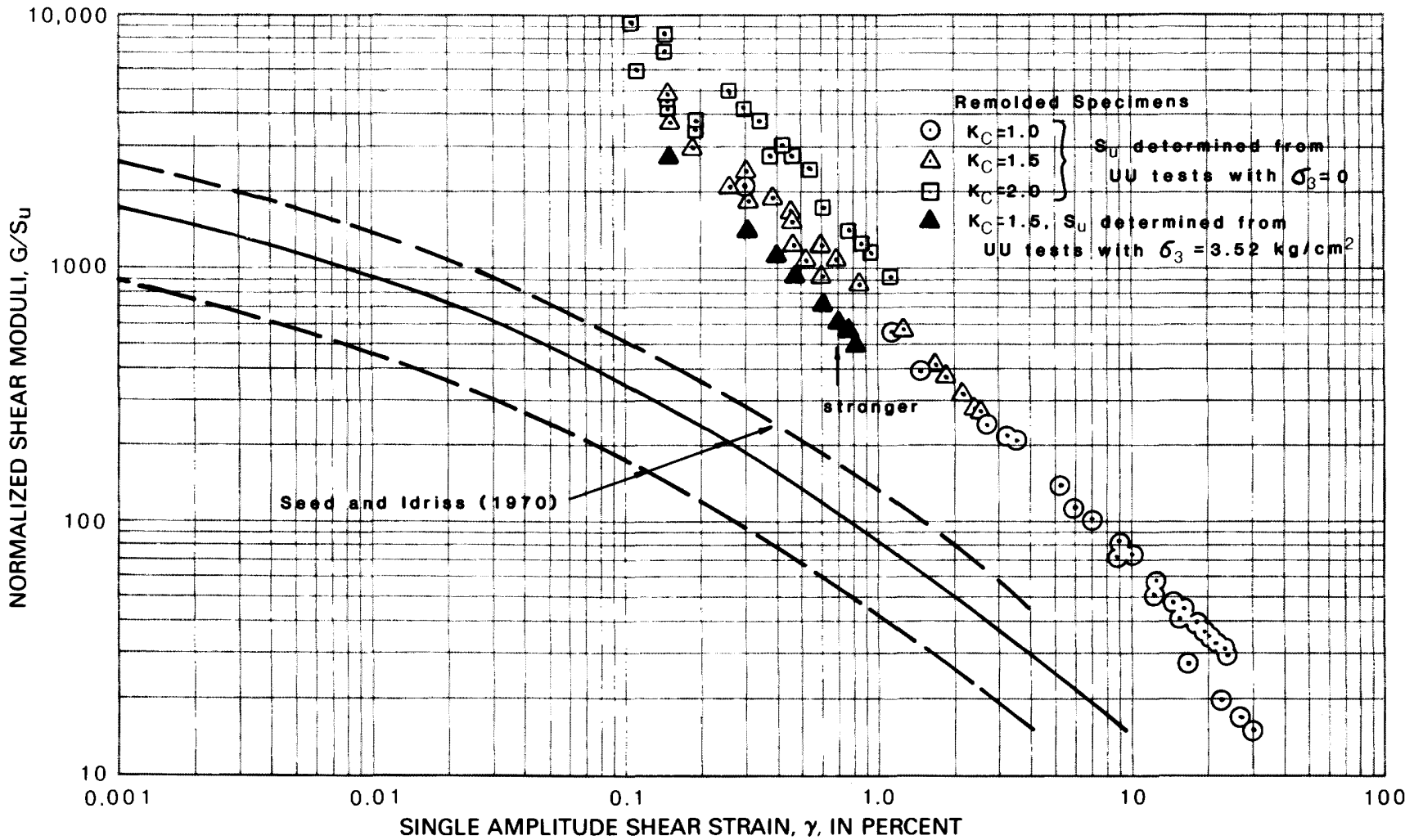

Figure 41. Normalized shear moduli for remolded specimens using shear strengths determined from unconsolidated-undrained tests. Note the two different confining pressures, $\sigma_{3}$, for a consolidation ratio of 1.5. Data points suggest higher strength than the Seed and Idriss (1970) normalized moduli curves would suggest.

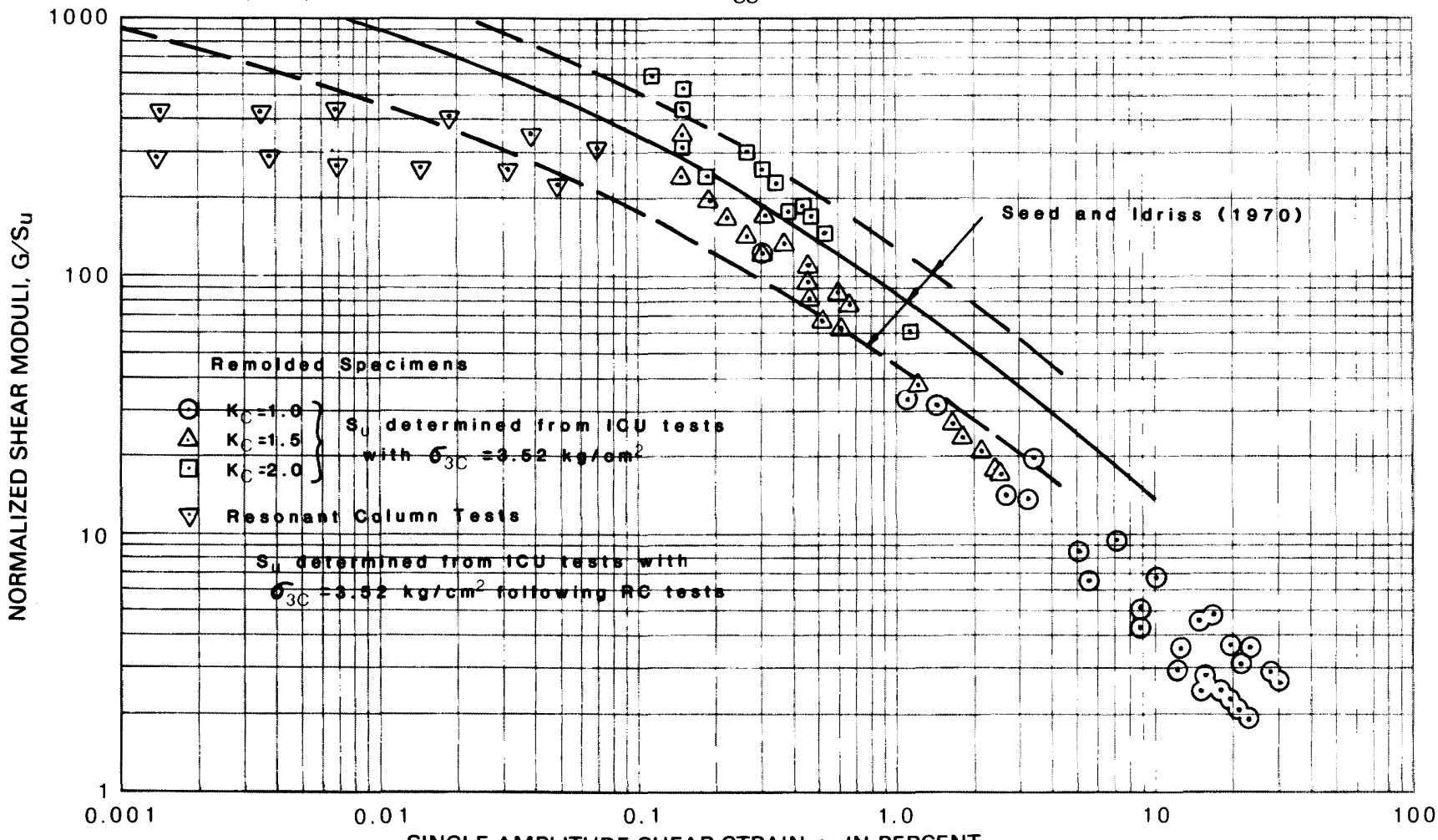

SINGLE AMPLITUDE SHEAR STRAIN $\boldsymbol{\gamma}$, IN PERCENT

Figure 42. Normalized shear moduli for remolded specimens using shear strengths determined from isotropically consolidatedundrained (ICU) tests. The Seed and Idriss (1970) moduli curves from figure 41 are in much closer agreement with data points based upon ICU tests. The low-strain resonant column data points (from Updike and others, 1982) show reasonable continuity with the cyclic triaxial test data. 


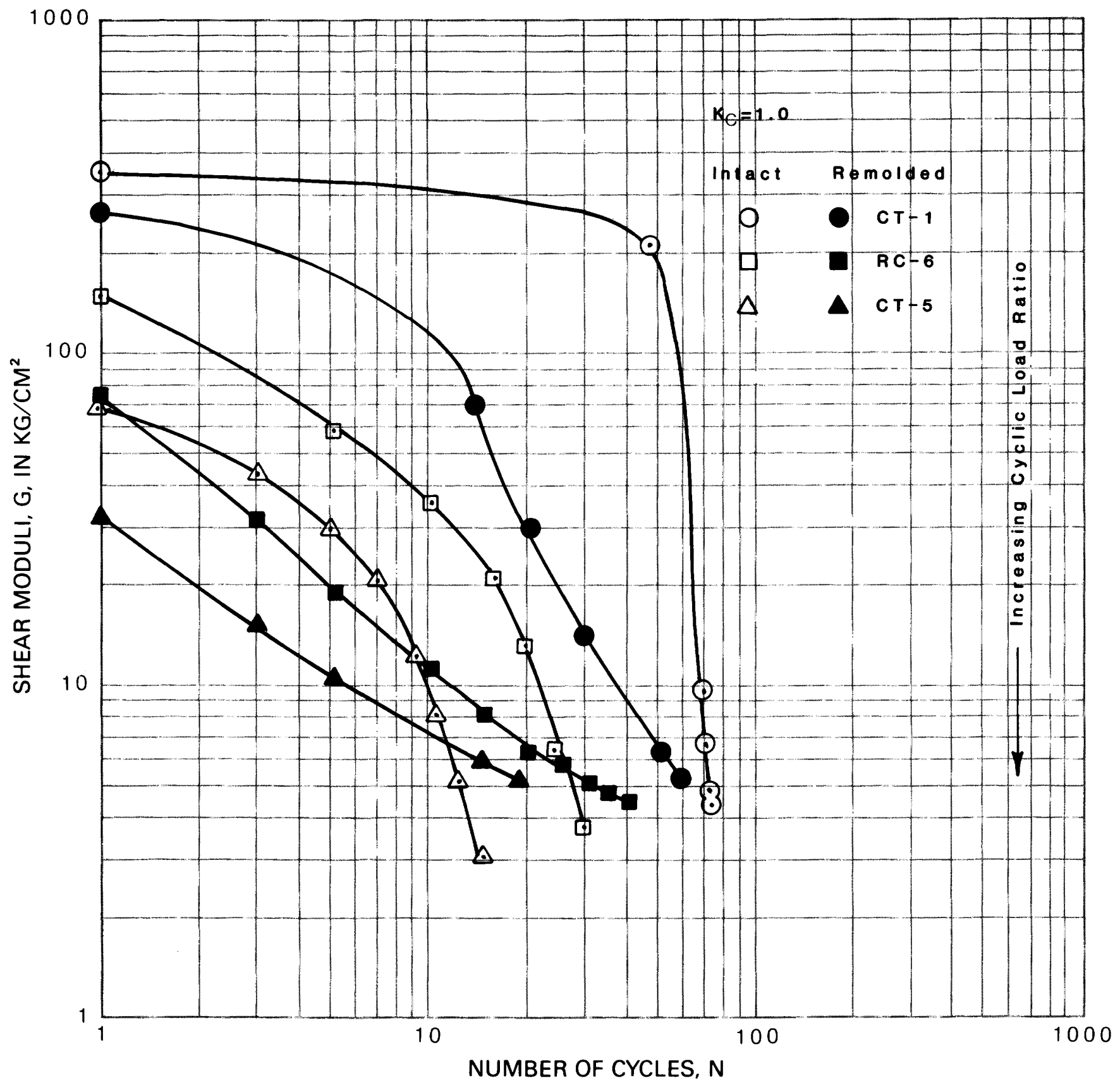

Figure 43. A comparison of shear moduli with respect to number of cycles for the intact and remolded states of three specimens, all at a consolidation ratio of 1.0. Specimens CT-1 and CT-5 represent facies F.IV of the Bootlegger Cove Formation; specimen RC -6 is from facies F.II of the Bootlegger Cove Formation. 


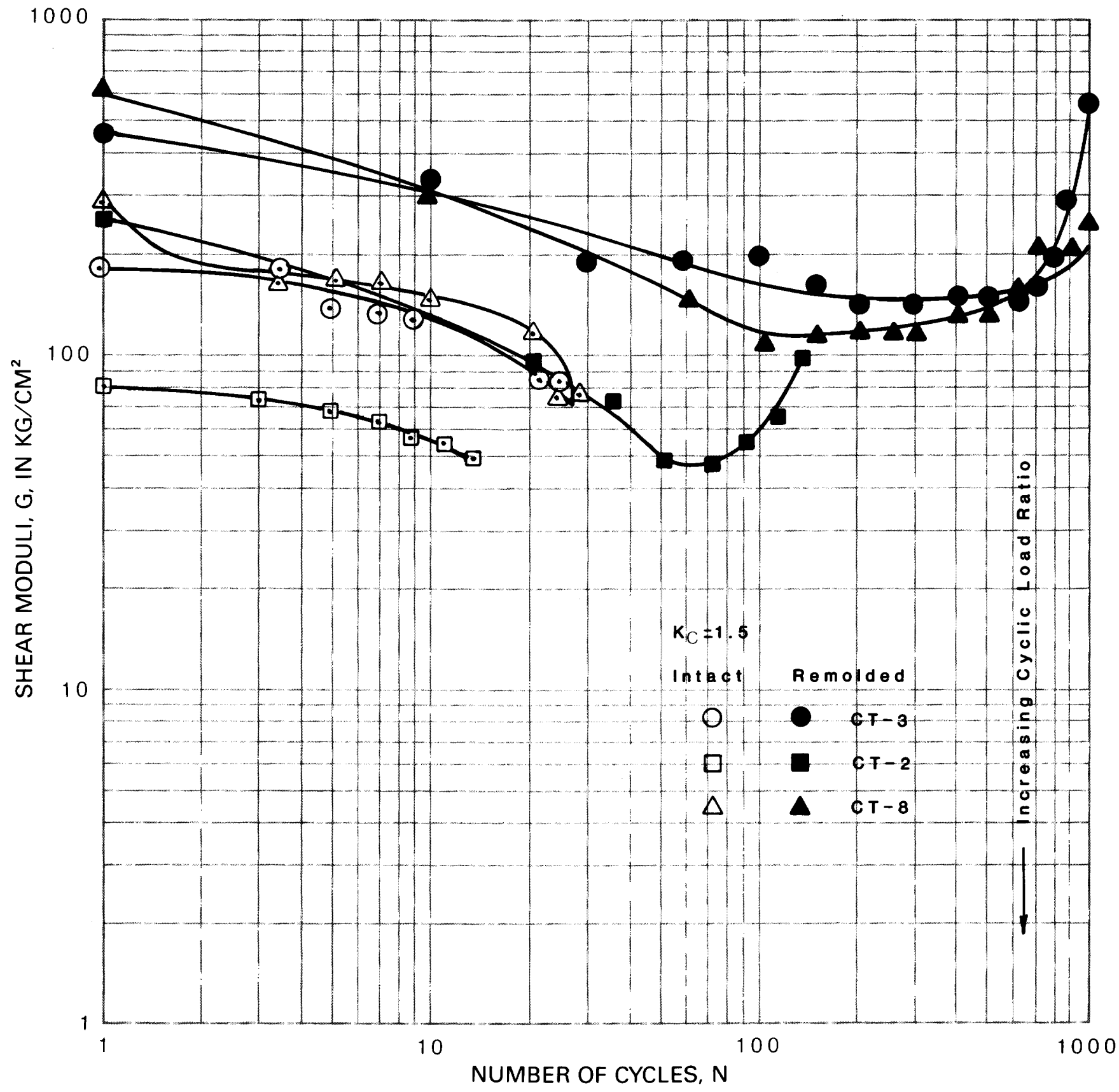

Figure 44. A comparison of shear moduli with respect to number of cycles for the intact and remolded states of three specimens, all at a consolidation ratio of 1.5. Specimens CT-2 and CT-8 represent facies F.II of the Bootlegger Cove Formation; specimen $\mathrm{CT}-3$ is from facies F.III of the Bootlegger Cove Formation. 


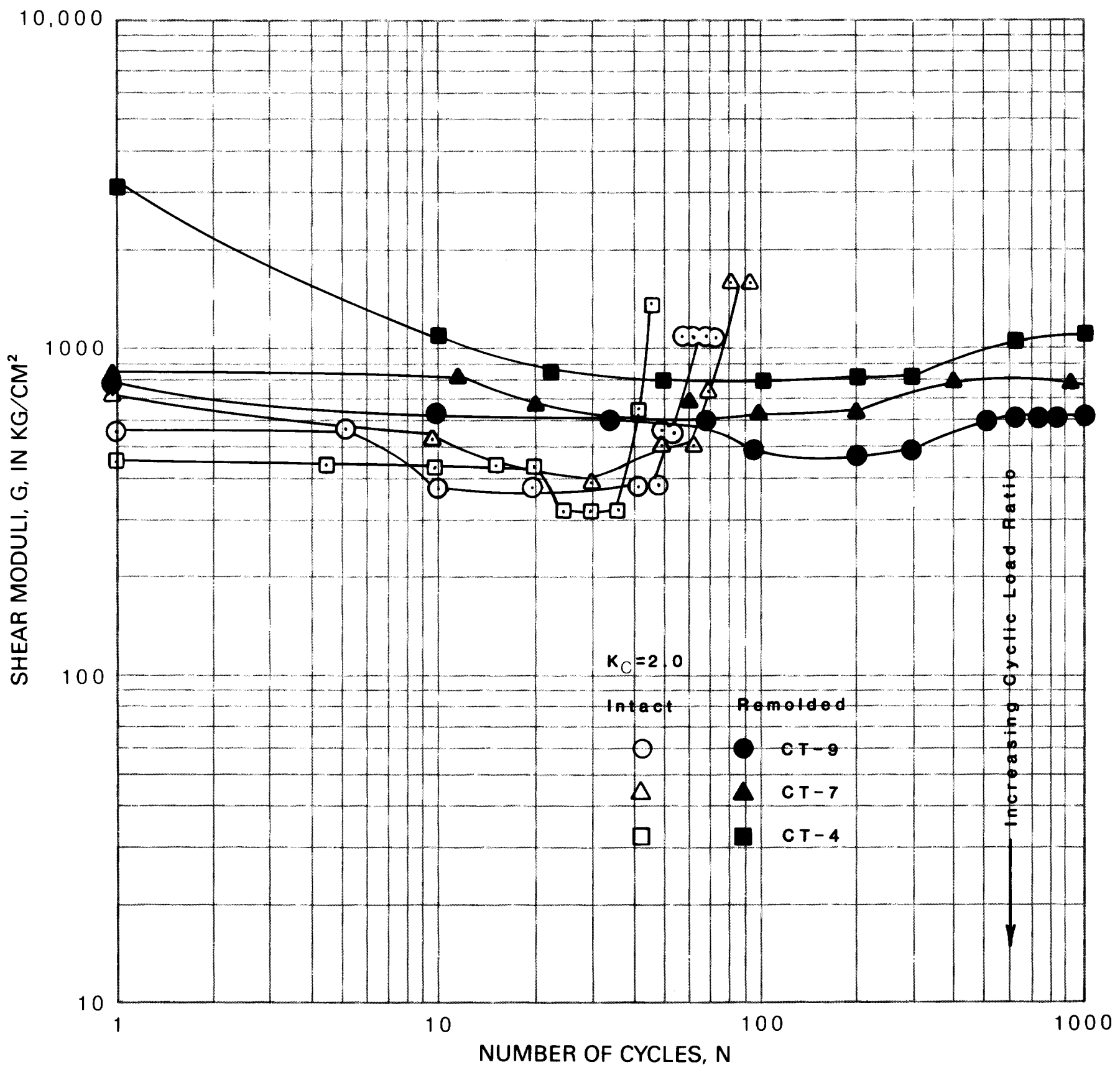

Figure 45. A comparison of shear moduli with respect to number of cycles for the intact and remolded states of three specimens, all at a consolidation ratio of 2.0. Specimens CT-4 and CT-7 represent facies F.IV of the Bootlegger Cove Formation; specimen CT-9 is from facies F.II of the Bootlegger Cove Formation. 


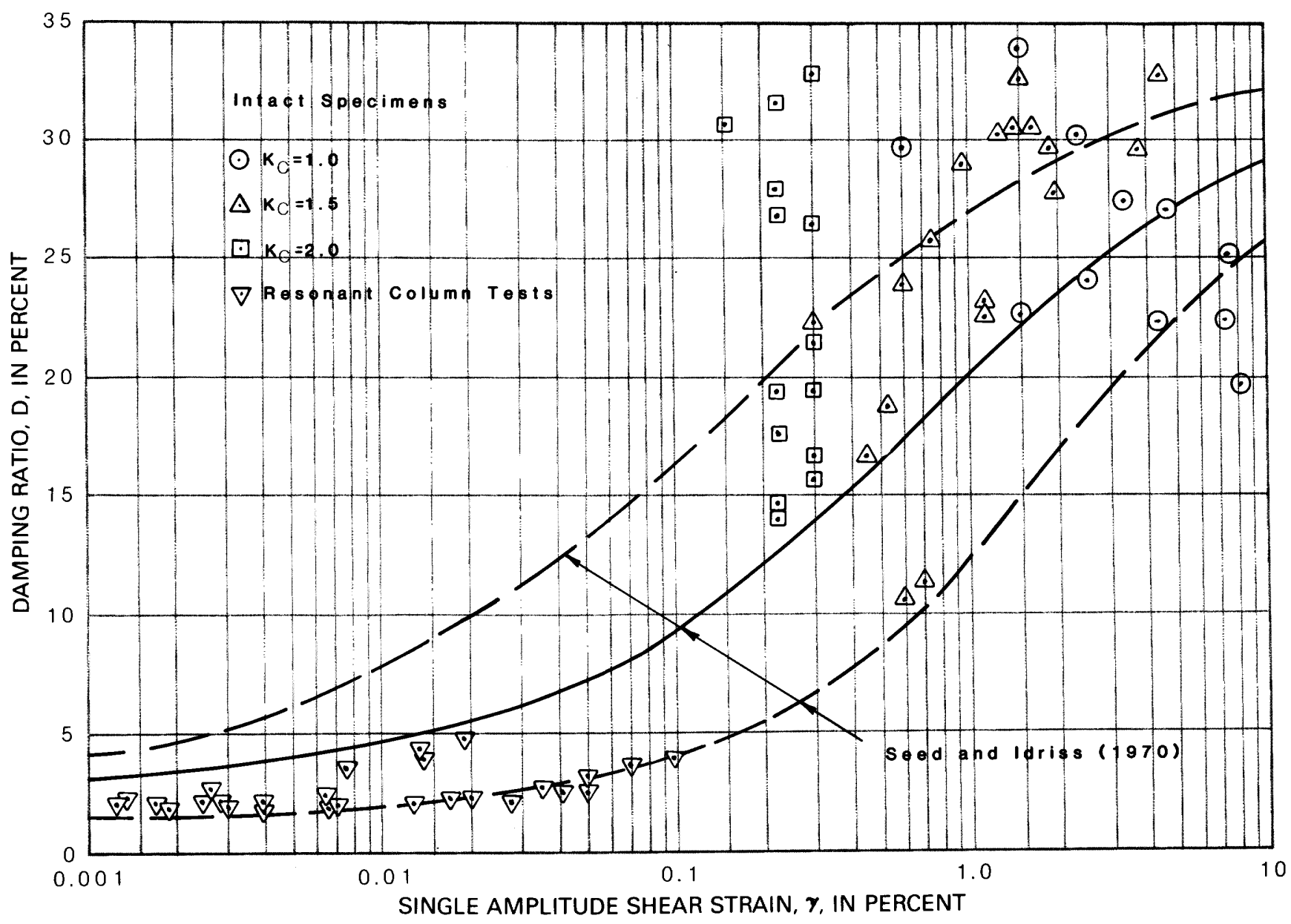

Figure 46. Damping ratios versus percent strain for intact specimens tested at various consolidation ratios. Damping ratio curves from Seed and Idriss (1970) and data points from resonant column tests (Updike and others, 1982) are also shown. 


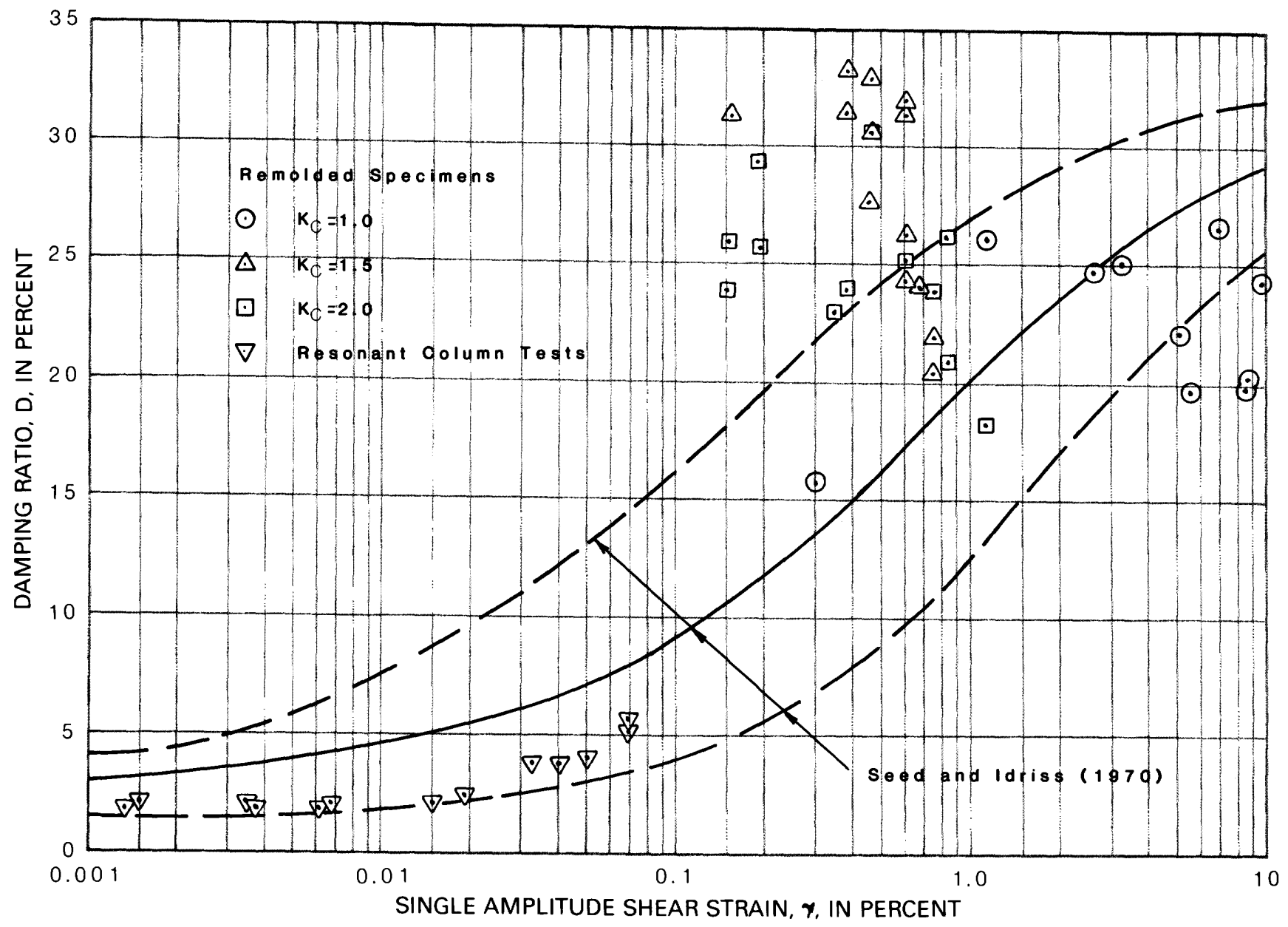

Figure 47. Damping ratios versus percent strain for remolded specimens tested at various consolidation ratios. Damping ratio curves from Seed and Idriss (1970) and data points from resonant column tests (Updike and others, 1982) are also shown. 






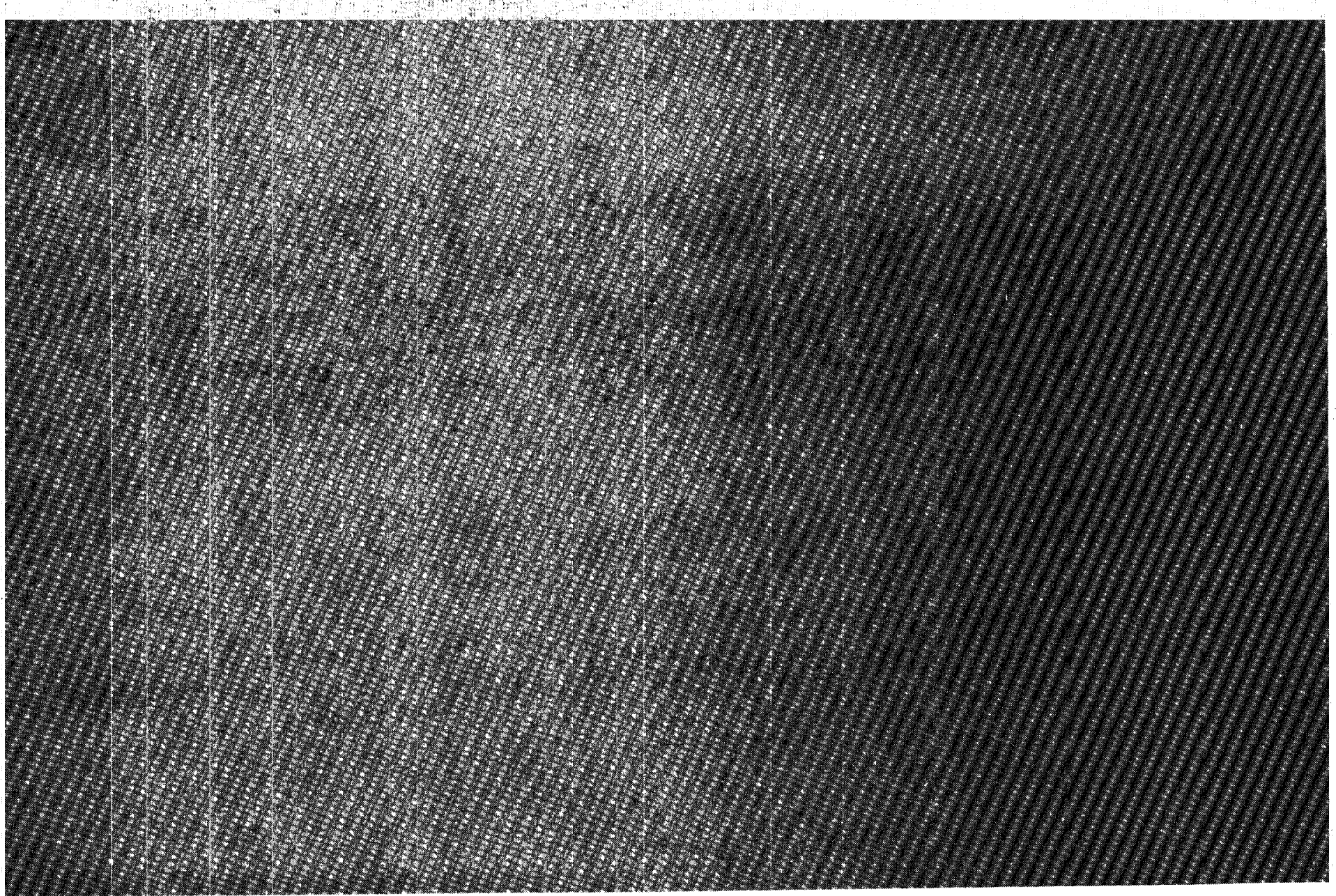

